\title{
Awakening the "Sleeping Beauty of the Peace Palace" - The Two-Dimensional Role of Arbitration in the Pacific Settlement of Interstate Territorial Disputes Involving Armed Conflict
}

by

Tamar Meshel

A thesis submitted in conformity with the requirements

for the degree of Master of Laws

Faculty of Law

University of Toronto

(C) Copyright by Tamar Meshel 2013 


\title{
Awakening the "Sleeping Beauty of the Peace Palace"1 - The Two-Dimensional Role of Arbitration in the Pacific Settlement of Interstate Territorial Disputes Involving Armed Conflict
}

\author{
Tamar Meshel \\ Master of Laws \\ Faculty of Law \\ University of Toronto
}

2013

\begin{abstract}
Interstate arbitration is commonly viewed as an essentially judicial process, suitable for the resolution of legal questions but inappropriate to deal with "political" issues. This conception, however, arguably flies in the face of both the origins and historical function of interstate arbitration and the complex legal-political nature of most interstate disputes. This paper offers an alternative account of interstate arbitration, which views it as a sui generis hybrid mechanism that combines "legal" and "diplomatic" dimensions to effectively resolve all aspects of interstate disputes. The paper examines this proposed account by analyzing four complex interstate territorial disputes that were submitted to arbitration and assessing the extent to which these two dimensions were recognized and employed, and how this may have affected the resolution of the disputes. Based on this analysis, the paper offers a two-dimensional operative framework intended to guide states and arbitrators in the resolution of future complex interstate disputes.
\end{abstract}

\footnotetext{
${ }^{1}$ Sam Muller \& Wim Mijs, “The Flame Rekindled” (1993) 6(2) Leiden J Int'1 L 203 at 204 [Muller \& Mijs]. 


\section{Acknowledgments}

I wish to thank my supervisor, Professor Karen Knop of the University of Toronto Faculty of

Law, whose patience, guidance, and insight have been invaluable to my thesis. I also wish to thank my parents for their infinite support and encouragement. 


\section{Table of Contents}

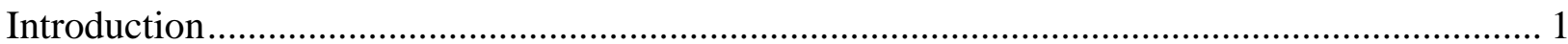

1 Research objectives and theoretical framework...................................................... 4

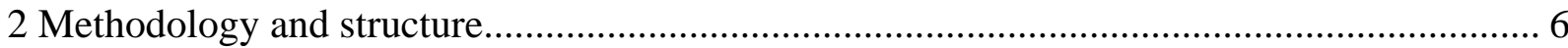

Chapter 1 Introduction to Interstate Territorial Disputes and Interstate Arbitration ................... 9

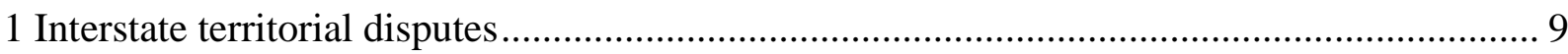

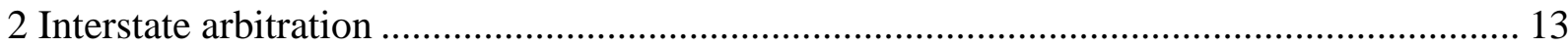

2.1 The historical origins and purpose of interstate arbitration................................. 13

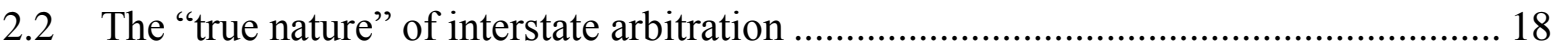

Chapter 2 Interstate Territorial Disputes Involving Armed Conflict- Case Studies ................... 25

1 The Beagle Channel Arbitration, 1977 .......................................................................... 25

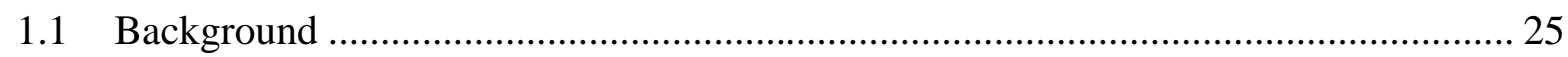

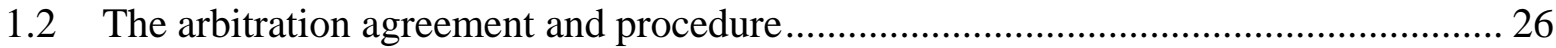

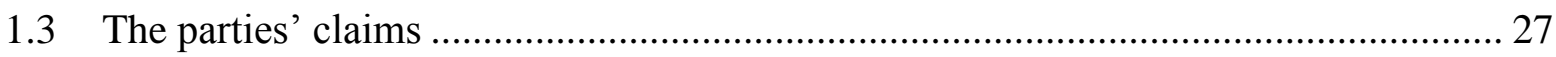

1.4 The arbitral tribunal's decision making process............................................... 29

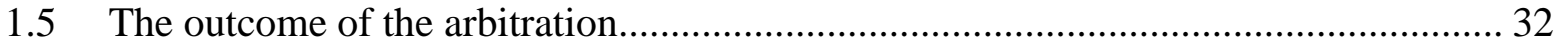

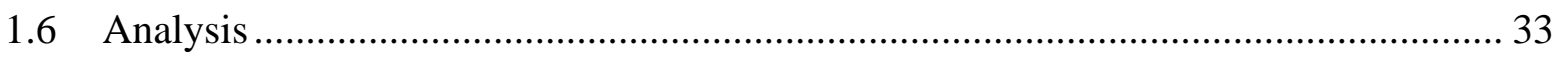

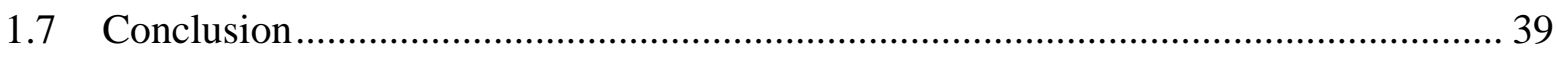

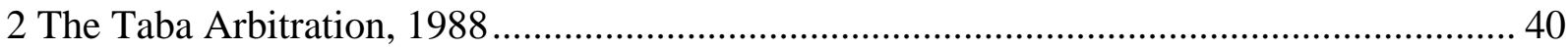

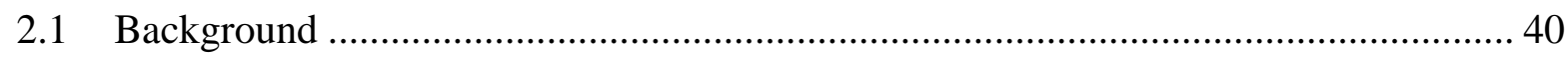

2.2 The arbitration agreement and procedure ..................................................... 42

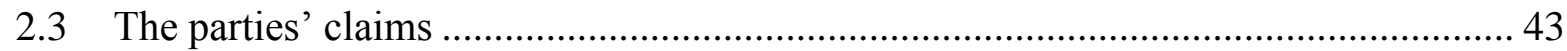

2.4 The arbitral tribunal's decision making process.............................................. 45

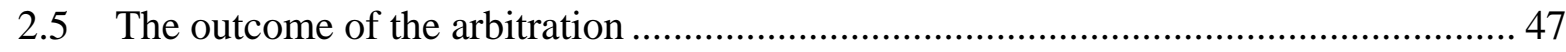

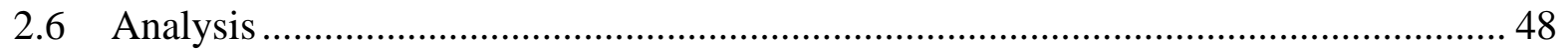

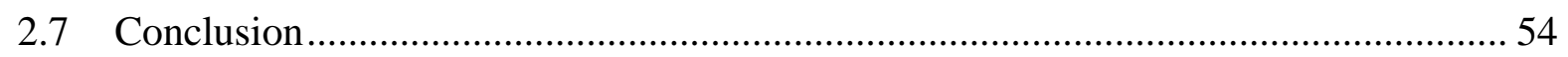

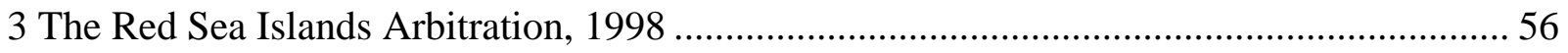

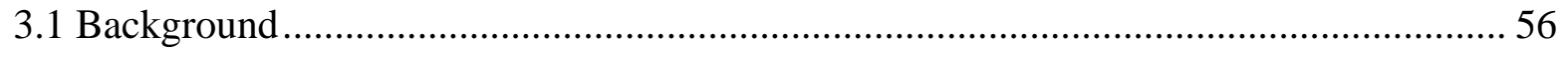

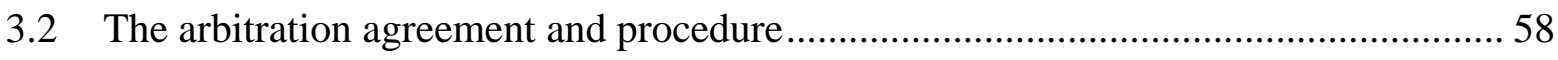

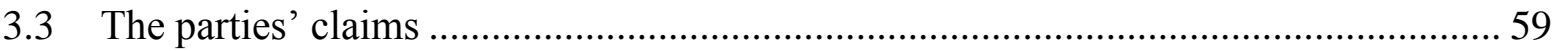


3.4 The arbitral tribunal's decision making process................................................. 61

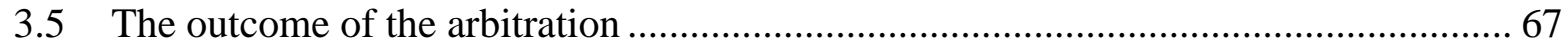

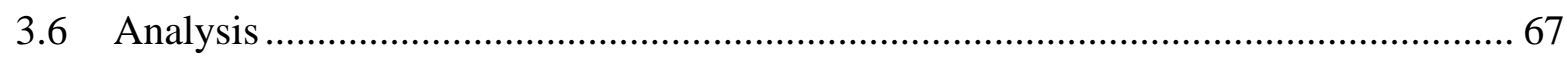

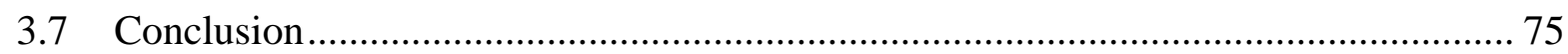

4 The Eritrea-Ethiopia Boundary Commission, 2002 ........................................................ 77

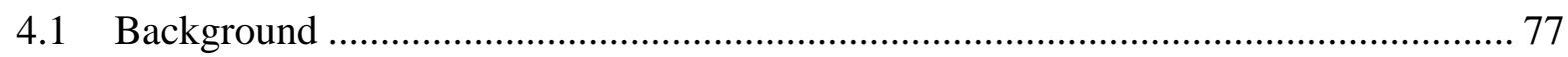

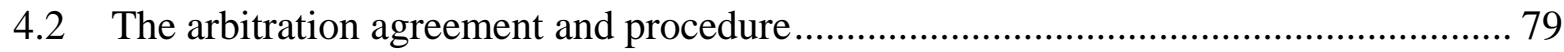

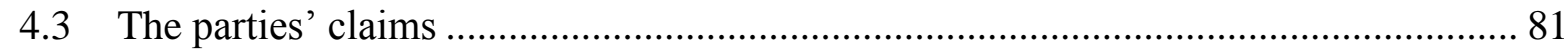

4.4 The commission's decision making process ................................................... 81

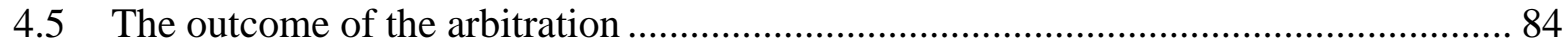

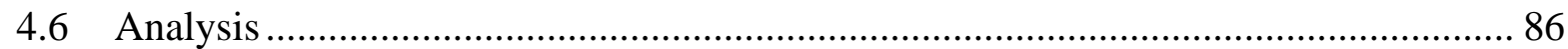

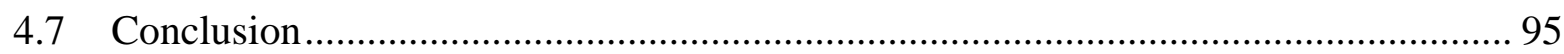

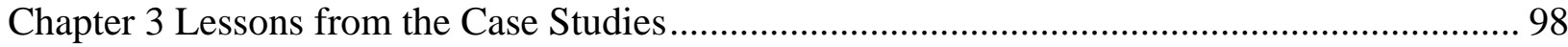

1 A preliminary framework for interstate arbitration .................................................... 99

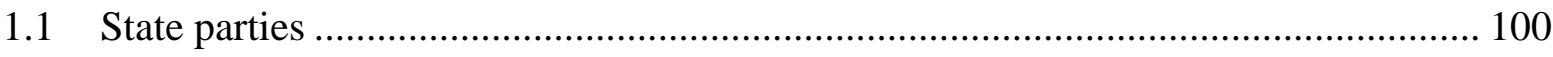

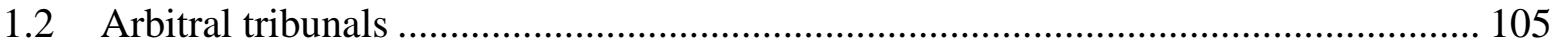

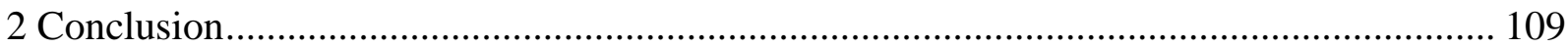

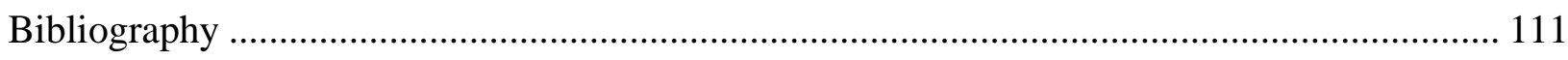

1 Arbitral Awards and Related Documents......................................................................... 111

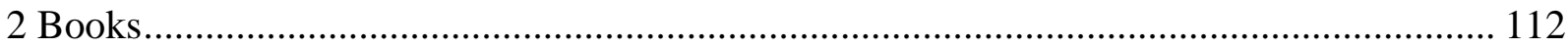

3 Book Chapters and Collections of Essays................................................................. 115

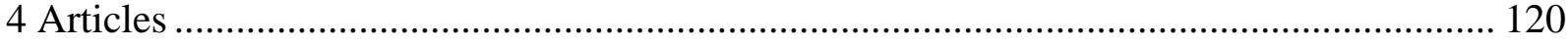

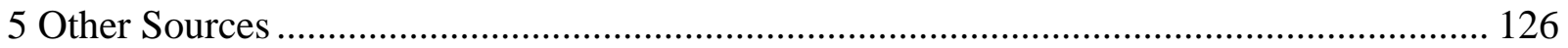




\section{Introduction}

Progress there will ever be in arbitration. We must ever develop it. But to develop it more and more, we must not change its nature ${ }^{2}$

International arbitration ${ }^{3}$ has been increasingly employed to resolve a wide range of transnational disputes, including private disputes between individuals or corporations, private-public disputes between individuals or companies and states, and certain types of public disputes between states. ${ }^{4}$ Despite this wide range of application and arbitration's proven effectiveness, it has been relatively scarcely used over the last century to resolve interstate disputes involving "political" or extra-legal issues, even where such disputes resulted in war or armed hostilities. ${ }^{5}$ The reluctance of states to employ arbitration in the resolution of politically sensitive interstate disputes is arguably rooted in its modern perception as an essentially "legal" or "judicial" process, suitable

\footnotetext{
2 J.B. Scott, quoted in M.C.W. Pinto, "Structure, Process, Outcome: Thoughts on the 'Essence' of International Arbitration" (1993) 6 Leiden J Int'l L 241 at 264 [Pinto, "Structure, Process, Outcome"].

${ }^{3}$ In its contemporary form, international arbitration has been defined as "a means by which international disputes can be definitively resolved, pursuant to the parties' agreement, by independent, non-governmental decision-makers, selected by or for the parties applying neutral judicial procedures that provide the parties an opportunity to be heard", Gary B. Born, International Commercial Arbitration (Kluwer Law International, 2009) at 65.

${ }^{4}$ John Collier \& Vaughan Lowe, The Settlement of Disputes in International Law: Institutions and Procedures (Oxford: Oxford University Press, 1999), at 6, 20 [Collier \& Lowe]; Francisco Orrego Vicuña, International Dispute Settlement in an Evolving Global Society: Constitutionalization, Accessibility, Privatization (Cambridge: Cambridge University Press, 2004) at 109 [Vicuña]; Michael Chapman, "The Interlaced History of Public and Commercial Arbitration, 1794 to 1999" in The International Bureau of the Permanent Court of Arbitration, ed, International Alternative Dispute Resolution: Past, Present and Future (The Hague: Kluwer Law International, 2000), at 77 [Chapman]; M.C.W. Pinto, "The Prospects for International Arbitration: Inter-State Disputes" in A.H.A. Soons, ed, International Arbitration: Past and Prospects (The Netherlands: Martinus Nijhoff Publishers, 1990) 66-67 [Pinto, "Prospects"]; Boas Gideon, Public International Law: Contemporary Principles and Perspectives (Cheltenham: Edward Elgar, 2012) at 344 [Gideon].

5 "Political disputes" are generally viewed as "disputes of such a nature as to arouse national political passions, irrespective of whether they are capable or not of settlement in conformity with international law", whereas "legal disputes" are generally viewed as "inter-state controversies in which the parties are divided on an issue of international law", P.H. Kooijmans, "International Arbitration in Historical Perspective: Past and Present, Comments on a paper by Professor L.B. Sohn" in A.H.A. Soons, ed, International Arbitration: Past and Prospects (The Netherlands: Martinus Nijhoff Publishers, 1990), at 27-28 [Kooijmans]. See also, e.g., Karl-Heinz Böckstiegel, "The Effectiveness of Inter-State Arbitration in Political Turmoil" (1993) 10(1) Journal of International Arbitration 43 at 47, 49 [Böckstiegel]; Carla S. Copeland, "The Use of Arbitration to Settle Territorial Disputes" (1998-1999) 67 Fordham L. Rev. 3073 at 3074, 3098, 3107 [Copeland]; Dean Rusk, "The Role and Problems of Arbitration with Respect to Political Disputes" in Thomas E. Carbonneau, ed, Resolving Transnational Disputes Through International Arbitration (Charlottesville: University Press of Virginia, 1982) at 15-20; Richard B. Bilder, "Some Limitations of Adjudication as an International Dispute Settlement Technique" in Thomas E. Carbonneau, ed, Resolving Transnational Disputes Through International Arbitration (Charlottesville: University Press of Virginia, 1982) at 3-14 [Bilder, "Some Limitations"]; Peter Wallensteen, Understanding Conflict Resolution (London: SAGE Publications Ltd, 2012) at 111 [Wallensteen].
} 
only for the resolution of legal questions through the application of legal principles, ${ }^{6}$ and frequently equated with international judicial settlement. ${ }^{7}$

This "judicialized" conception of interstate arbitration, however, arguably flies in the face of both its original nature and purpose and the complexity of many interstate disputes. Interstate arbitration was originally conceived as an alternative to judicial settlement, "for an arbitrator goes by the equity of a case, a judge by the strict law, and arbitration was invented with the express purpose of securing full power for equity". ${ }^{8}$ Therefore, the emphasis in the modern practice of interstate arbitration on the application of law to disputes rather than their just and effective settlement ${ }^{9}$ is arguably antithetical to its "true nature". ${ }^{10}$ The complex nature of many interstate disputes also calls into question the validity of this "judicialized" conception of arbitration. Such disputes frequently involve both "legal" and "political" aspects ${ }^{11}$ that are

\footnotetext{
${ }^{6}$ See, e.g., D.W. Bowett, Contemporary Developments in Legal Techniques in the Settlement of Disputes, Coursepack, (Hague Academy of International Law, Recueil des Cours Académie de droit international de la Haye, 1983) at 178 [Bowett]; Andrew Calpham, Brierly's Law of Nations, 7th ed (Oxford: Oxford University Press, 2012) at 432 [Calpham]; J.G. Merrills, "International Boundary Disputes in Theory and in Practice: Precedents Established" in Julie Dahlitz, ed, Peaceful Resolution of Major International Disputes (New York: United Nations, 1999) at 101-102 [Merrills, "International Boundary Disputes"]; Study Group of the David Davies Memorial Institute of International Studies, International Disputes: The Legal Aspects (London: Europa Publications, 1972) at 20, 59-60 [Study Group]; Schweigman David. The Authority of the Security Council Under Chapter VII of the UN Charter: Legal Limits and the Role of the International Court of Justice (The Hague: Kluwer Law International, 2001) at 265 [Schweigman]; Copeland, Ibid at 3098; A.L.W. Munkman, "Adjudication and Adjustment International Judicial Decisions and the Settlement of Territorial and Boundary Disputes (1972-1973) 46 Brit. Y. B. Int'l L. 1 at 12 [Munkman]; Jacob Bercovitch \& Judith Fretter, Regional Guide to International Conflict and Management From 1945 to 2003 (California: CQ Press, 2004) at 14 [Bercovitch \& Fretter]; Böckstiegel, Ibid at 4344, 47, 49; Ho-Won Jeong, Peace and Conflict Studies: An Introduction (Hants, England: Ashgate Publishing Ltd., 2000) at 176 [Jeong]; Christine Gray \& Benedict Kingsbury, "Inter-state Arbitration since 1945: Overview and Evaluation" in Mark W. Janis, ed, International Courts for the Twenty-First Century (Dordrecht, Boston: Martinus Nijhoff Publishers, 1992) at 55 [Gray \& Kingsbury].

Nonetheless, others have argued that arbitration is appropriate for the resolution of disputes concerning "vital interests" if it is applied properly. See, e.g., Gerald Rabow, Peace Through Agreement: Replacing War with NonViolent Dispute-Resolution Methods (New York: Praeger Publishers, 1990) [Rabow]; Pinto, "Prospects", supra note 4 at 65; James D. Fry, "Arbitrating Arms Control Disputes" (2008) 44 Stan J Int'l L 359 at 419 [Fry].

${ }^{7}$ See, e.g., Edward McWhinney, "The International Court as Constitutional Court and the Blurring of the Arbitral/Judicial Processes" (1993) 6 Leiden J Int'l L 279 at 283 [McWhinney]; Munkman, Ibid at 6; Pinto, "Prospects", supra note 4 at 95; Pinto, "Structure, Process, Outcome", supra note 2 at 241-242; Böckstiegel, supra note 5 at $43-44$.

${ }^{8}$ Pinto, "Prospects", supra note 4 at 66.

${ }^{9}$ Pinto, "Structure, Process, Outcome", supra note 2 at 60.

${ }^{10}$ M.C.W. Pinto, "Structure, Process, Outcome: Thoughts on the 'Essence' of International Arbitration" in Sam Muller and Wim Mijs, eds, The Flame Rekindled: New Hopes for International Arbitration (The Netherlands: Martinus Nijhoff Publishers, 1994) at 44 [Pinto, "The Flame Rekindled"].

${ }^{11}$ Bercovitch \& Fretter, supra note 6 at 27; Pinto, "Prospects", supra note 4 at 85, 94-95; Bowett, supra note 6 at 177; Collier \& Lowe, supra note 4 at 7-8; Malcolm N. Shaw, "Peaceful Resolution of 'Political Disputes': The Desirable Parameters of ICJ Jurisdiction" in Julie Dahlitz, ed, Peaceful Resolution of Major International Disputes (New York: United Nations, 1999) at 49-50, 52, 62 [Shaw, "Political Disputes"]; Study Group, supra note 6 at 6-7, 58-59; Schweigman, supra note 6 at 264; Fry, supra note 6 at 419; Böckstiegel, supra note 5 at 43; Vicuña, supra
} 
strongly intertwined and therefore, in order to be resolved fully and definitely, these disputes require a mechanism capable of addressing and resolving both aspects effectively.

This paper argues that arbitration can constitute such a mechanism if its "traditional quality"12 and purpose of resolving issues "not suitable for judicial settlement"13 is revived. It posits that interstate arbitration should be understood and applied to complex interstate disputes as a sui generis hybrid mechanism designed to provide binding and reasoned, but also fair and effective, resolution of all aspects of interstate disputes. ${ }^{14}$ This traditional hybrid nature is manifested in two separate but interrelated dimensions of interstate arbitration.

The first is the "legal dimension", which allows state parties to submit legal questions to the arbitral tribunal and to present arguments grounded in law; guarantees procedural safeguards such as the arbitrators' consideration of all arguments raised by the parties and their provision of reasons for their decisions; allows the tribunal to apply law, including equitable principles, ${ }^{15}$ in its decision making; and accords the arbitral award its legally binding nature. While in this dimension the arbitrators" function is akin to that of judges, they should avoid a "formalistic"16 approach to the interpretation and application of the law that is rigid, literal, and legalistic. Rather, this role of the "arbitrator as judge" in interstate arbitration is to be carried out flexibly and in accordance with the specific circumstances of the dispute in question.

The second dimension of interstate arbitration is the "diplomatic dimension", which allows state parties to submit politically sensitive questions to the arbitral tribunal and to advance extra-legal arguments based on political, historical, economic, or customary considerations, and allows the

\footnotetext{
note 4 at 101 ; Muller \& Mijs, supra note 1 at 210.

12 Pinto, "Prospects", supra note 4 at 85-86.

${ }^{13}$ Gray \& Kingsbury, supra note 6 at 55. See also, Fry, supra note 6 at 419; Jacques Werner, "Interstate Political Arbitration: What Lies Next?" (1992) 9:1 J Int'1 Arb 69 at 419 [Werner].

${ }^{14}$ Munkman, supra note 6 at 2; Rabow, supra note 6 at 127.

${ }^{15}$ Decisions in equity are generally considered to be part of the law and therefore distinct from decisions ex aequo et bono, Leon Trakman, "Ex Aequo et Bono: Demystifying an Ancient Concept” (2007-2008) 8 Chi. J. Int'l L. 621 at 628 [Trakman]. "Equity aims at proper application of law in a particular case in order to avoid decisions that are a reflection of abstract principles detached from the circumstances that a court or arbitration tribunal may face", Manfred Lachs, "Equity in Arbitration and in Judicial Settlement of Disputes" (1993) 6 Leiden J Int'l L 323 at 291 [Lachs, "Equity in Arbitration"].

16 "Legal formalism" is commonly defined as "the use of deductive logic to derive the outcome of a case from premises accepted as authoritative", Richard A. Posner, "Legal Formalism, Legal Realism, and the Interpretation of Statutes and the Constitution (1986-1987) 37 Case W Res L Rev 179 at 180-181. In the context of interstate arbitration, this paper argues that while law may be relevant to the resolution of a dispute, legal formalism that leads to narrow, conservative, and restrained decisions should be avoided.
} 
tribunal to decide such questions ex aequo et bono, ${ }^{17}$ or in accordance with what is fair, just, reasonable, or effective in the circumstances of the case. In this dimension, the arbitrators act as diplomats of sorts, who look beyond the law to consider both extra-legal factors and the realities on the ground in order to devise a compromise and avoid a "winner-takes-all" outcome. This role of the "arbitrator as diplomat" is intended to circumvent the judicial preoccupation with legal rules and principles where these are inapplicable to the dispute or incapable of providing a comprehensive, practical, and just resolution.

It is the combination of these two dimensions that produces the traditional sui generis hybrid nature of interstate arbitration and that has largely been disregarded in its modern "judicialized" form. The contemporary practice of interstate arbitration instead focuses almost exclusively on the "legal dimension" of the arbitral process, with state parties submitting only legal issues to arbitration and arbitrators exercising their role as "judges" narrowly by applying strict legal principles to resolve such issues. The "diplomatic dimension" of the process, and with it the arbitrators' role as "diplomats", has been largely abandoned altogether. While the dual role of the arbitrator advanced by the two-dimensional account of interstate arbitration may seem overly demanding and omniscient, arbitrators would arguably be able to exercise this role successfully if state parties are truly committed to the arbitral process, and both the parties and the arbitrators approach and use it correctly. Moreover, arbitrators are arguably more likely to devise an effective and comprehensive solution to a complex interstate dispute if they are allowed to consider all relevant factors and decide on all relevant issues, both "legal" and "political".

\section{Research objectives and theoretical framework}

The objective of this paper is two-fold. First, it seeks to examine the proposed two-dimensional theory of interstate arbitration and consider how it may make it a more suitable mechanism for

\footnotetext{
${ }^{17}$ i.e., "according to what is equitable and good". While Article 38(2) of the ICJ Statute permits the Court to decide ex aequo et bono where the parties so agree, arguably only when a decision is not possible on legal grounds will the Court turn to equity. Thus far the Court's decisions in territorial disputes have not been based directly on equitable principles, The Carter Center, "Approaches to Solving Territorial Conflicts: Sources, Situations, Scenarios, and Suggestions" (May 2010), online: The Carter <http://www.cartercenter.org/resources/pdfs/news/peace_publications/conflict_resolution/Solving_Territorial_Confl icts.pdf> at 2-3 [The Carter Center]; M. Lachs, "Arbitration and International Adjudication" in A.H.A. Soons, ed, International Arbitration: Past and Prospects (The Netherlands: Martinus Nijhoff Publishers, 1990) at 41 [Lachs, "Arbitration and International Adjudication"]; Loretta Malintoppi, "Methods of Dispute Resolution in Inter-State Litigation: When States Go To Arbitration Rather Than Adjudication" (2006) 5 Law \& Prac Int'l Cts \& Tribunals 133 at 151 [Malintoppi]; J.G. Merrills, International Dispute Settlement (Cambridge: Cambridge University Press, 2011) at 95 [Merrills, "International Dispute Settlement"].
} 
the resolution of complex interstate disputes. Second, this paper aims to identify those features of two-dimensional interstate arbitration that appear to make it such a suitable mechanism and to transform them into practical tools that would facilitate its effective ${ }^{18}$ use in the future. $^{19}$

This evaluation of the two-dimensional theory of interstate arbitration is carried out in the context of interstate territorial disputes. ${ }^{20}$ This specific category of interstate disputes was selected for two reasons. First, territorial disputes tend to be particularly complex, as they involve both fundamental legal issues, such as acquisition of title, and significant extra-legal issues, such as national identity or economic stability. ${ }^{21}$ This complex nature arguably makes interstate territorial disputes an ideal testing ground for the two-dimensional theory of interstate arbitration. Second, since interstate territorial disputes often lead to armed conflict or war, ${ }^{22}$ which may have devastating implications in the twenty-first century, ${ }^{23}$ the persistence of these disputes constitutes one the greatest dangers to the maintenance of international peace and security and therefore a matter of grave concern to the international community. ${ }^{24}$ These concerns, coupled with states' continuous obligation to resolve their disputes peacefully, ${ }^{25}$ underscore the need for creative new ways to settle interstate territorial conflicts effectively.

The limitations of the proposed two-dimensional theory of interstate arbitration should also be clarified. Considering the wide range of dispute resolution mechanisms available for the settlement of interstate disputes, this paper does not purport to argue that other mechanisms

\footnotetext{
18 "Effectiveness" in this context is assessed by states' voluntary compliance with the outcome of the arbitration and the conclusive resolution of their dispute.

${ }^{19}$ It has been suggested that arriving "at a commonly held perception of [the] essentials" of interstate arbitration is a "pre-requisite to formulating rules which all States might be invited to accept", Pinto, "Prospects", supra note 4 at 91-99; Pinto, "Structure, Process, Outcome", supra note 2 at 263-264.

${ }^{20}$ For the purpose of this paper, "interstate territorial disputes" include disputes between two or more states over territorial title or boundary issues. In the context of the settlement of disputes over territorial sovereignty, the distinction between territorial and boundary disputes is largely considered as insignificant, Junwu Pan, Toward a New Framework for Peaceful Settlement of China's Territorial and Boundary Disputes (Leiden, The Netherlands: Martinus Nijhoff Publishers, 2009) at 27 [Pan].

${ }^{21}$ Wallensteen, supra note 5 at 111.

${ }^{22}$ It has been argued that "the risk for armed conflict is greatest over the issue of conflicting claims to territory" and that "territorial disputes historically have been a frequent cause of international wars", Todd L. Allee \& Paul K. Huth, "The Pursuit of Legal Settlements to Territorial Disputes" (2006) 23 Conflict Management and Peace Science 285 at 285 [Allee \& Huth]. See also, Copeland, supra note 5 at 3108; Bercovitch \& Fretter, supra note 6 at 10; Vidmar Srecko, “Compulsory Inter-State Arbitration of Territorial Disputes" (2002-2003) 31 Denv J Int'l L \& Pol'y 87 at 89 [Srecko]; Pan, supra note 20 at 30.

${ }^{23}$ Bercovitch \& Fretter, supra note 6 at 11-12; Bilder, "Some Limitations", supra note 5 at 13-14; W. Michael Reisman, "Stopping Wars and Making Peace: Reflections on the Ideology and Practice of Conflict Termination in Contemporary World Politics" (1998) 6 Tul J Int'l \& Comp L 5 at 7 [Reisman, "Reflections"].

${ }^{24}$ Srecko, supra note 22 at 98 .

${ }^{25}$ Charter of the United Nations, 24 October 1945, 1 UNTS XVI, Articles 2(3), 33(1); Pan, supra note 20 at 31.
} 
should not be used prior to, or in parallel with, arbitration. ${ }^{26}$ It also does not posit that arbitration necessarily constitutes the best mechanism for the resolution of every interstate dispute or, even where this is the case, that it does not ultimately depend, as any other interstate dispute settlement method, on the political will and responsible behavior of governments, ${ }^{27}$ and on their recognition that they would be better off making peace rather than waging war. ${ }^{28}$ Finally, the two-dimensional account of interstate arbitration advanced in this paper is intended to counter the modern perception and use, or rather, as this paper argues, misperception and misuse, of the arbitral process, and aims to revive its traditional nature and original purpose. This account is therefore largely internal to interstate arbitration itself, its history and practice, and is not presented as the only legitimate view of arbitration as a dispute resolution mechanism or of the respective roles of law and diplomacy in its application.

This paper hopes to contribute to the existing interstate conflict resolution scholarship both by reintroducing and reinforcing arbitration's two-dimensional true nature and by creating a preliminary operative framework ${ }^{29}$ that states and arbitral tribunals can implement to effectively resolve complex and violent interstate disputes. ${ }^{30}$ Such a framework will hopefully assist in developing states' familiarity with, and understanding of, the particularities of interstate arbitration and "inspire confidence" in the process, ${ }^{31}$ which is essential for arbitration to be accepted as a just mechanism for the settlement of politically sensitive interstate disputes. ${ }^{32}$

\section{Methodology and structure}

The paper will examine four interstate territorial disputes involving armed conflict in which

26 Michael E. Schneider, "Combining Arbitration with Conciliation” (2004) TDM 1, online: TDM <www.transnational-dispute-management.com/article.asp?key=35> at 67 [Schneider]; Merrills, "International Dispute Settlement", supra note 17 at 162.

${ }^{27}$ Hans Corell, "The Feasibility of Implementing the Hague/St. Petersburg Centennial Recommendations Under the UN System" in Julie Dahlitz, ed, Peaceful Resolution of Major International Disputes (New York: United Nations, 1999) at 33 [Corell]; William G. Hopkinson, "Overcoming Diplomatic Inertia and Constraint in the Resolution of Major Conflict" in Julie Dahlitz, ed, Peaceful Resolution of Major International Disputes (New York: United Nations, 1999) at 80 [Hopkinson]; Merrills, "International Dispute Settlement", Ibid at 115.

${ }^{28}$ Reisman, "Reflections", supra note 23 at 22.

29 "Preliminary" in the sense that this framework should be viewed as initial in light of the limited scope of the present analysis.

${ }^{30}$ In other words, this paper seeks to examine "when [arbitration] is most effective and how to operationalize [its] effectiveness" in the context of complex interstate disputes, Stephen E. Gent \& Megan Shannon, "The Effectiveness of International Arbitration and Adjudication: Getting Into a Bind" (2010) 72(2) The Journal of Politics 366 at 378 [Gent \& Shannon].

${ }^{31}$ Werner, supra note 13 at 75.

${ }^{32}$ Study Group, supra note 6 at 39; Louise B. Sohn, "Peaceful Settlement of Disputes and International Security" (1987) 3(2) Negotiation Journal 155 at 157 [Sohn, "International Security”]. 
arbitration was employed, both successfully and unsuccessfully. ${ }^{33}$ These cases will be systematically analyzed and compared in order to assess the extent to which arbitration's "legal" and "diplomatic" dimensions were recognized and implemented by the state parties and the arbitral tribunals; whether and in what manner the arbitrators acted as "judges", "diplomats", or both; and how these factors may have influenced the outcome of the disputes. ${ }^{34}$ Based on these findings, the paper will attempt to construct a preliminary operative framework of "best practices" to guide states and arbitral tribunals in the proper application of arbitration to future complex interstate disputes. ${ }^{35}$

This proposed case study analysis is not intended to produce empirical data, establish causation, or provide a verifiable conclusion. Rather, it is an internal theoretical exercise aimed at examining the failures as well as the successes of past interstate territorial arbitrations from a two-dimensional perspective that supports the traditional hybrid nature of interstate arbitration this paper aims to revive. This analysis, moreover, relies mainly on secondary sources such as commentary of international law scholars and arbitrators, and focuses on those materials that support its underlying hypothesis. This is since the two-dimensional view of interstate arbitration suggested in this paper challenges the currently prevailing one-dimensional "judicialized" perception shared by most states, scholars, and practitioners. The purpose of this analysis, therefore, is not to provide an overview of the existing scholarship, which arguably perpetuates this (mis)perception, but rather to build on and further develop those materials that contribute to and support the alternative traditional account advanced in this paper.

The arbitrations examined and compared are: the 1977 Beagle Channel Arbitration between Chile and Argentina, the 1988 Taba Arbitration between Israel and Egypt, the 1998 Red Sea Islands Arbitration between Eritrea and Yemen, and the 2002 Eritrea-Ethiopia Boundary Arbitration. These cases were selected on the basis of the following criteria:

\footnotetext{
${ }^{33}$ The "success" of these arbitrations is assessed on the basis of the willingness of the parties to implement the arbitral award and the ability of the arbitral process to fully resolve the parties' dispute.

${ }^{34}$ Due to the limited scope of this analysis, it does not seek to establish any causal relationship between the way the arbitral process was perceived and applied in these cases and the ultimate success or failure of the arbitrations. Rather, it aims to identify similarities and differences between the successful and unsuccessful arbitrations in order to identify any potential patterns of effective two-dimensional arbitral practice.

${ }^{35}$ A similar approach was used with respect to mediation in Melanie C. Greenberg, John H. Barton \& Margaret E. McGuinness, eds, Words Over War: Mediation and Arbitration to Prevent Deadly Conflict (Oxford: Rowman \& Littlefield Publishers, Inc., 2000) [Greenberg, Barton \& McGuinness], and with respect to supranational adjudication in Laruence R. Helfer \& Anne-Marie Slaughter, "Toward a Theory of Effective Supranational Adjudication" (1997-1998) 107 Yale L.J. 273.
} 
1. They were all interstate disputes;

2. They all involved a territorial dispute, either concerning land or boundaries, which involved legal as well as political, historical, strategic, economic, or other important interests; and

3. They all involved some form of armed conflict or military confrontation between the parties. $^{36}$

Following a brief overview of the historical and contextual background of each dispute, the comparative analysis will focus on the extent to which the traditional two-dimensional nature of interstate arbitration was reflected in the arbitrations. To this end, a consistent method of analysis will be applied, focusing on the following substantive and procedural aspects:

1. The arbitration agreement concluded by the parties and related procedural aspects of the arbitration, including the applicable laws and the composition of the arbitral tribunal;

2. The issues in dispute and the parties' main claims and arguments;

3. The decision making process of the arbitrators, including their approach to their own role and to their mandate; and

4. The outcome of the arbitration, including the enforcement of the arbitral award and impact on the parties' dispute and long-term relationship.

The structure of the paper is as follows. Chapter 1 will provide a brief introduction to interstate territorial disputes and interstate arbitration, discuss why and how the modern one-dimensional "judicialized" conception of interstate arbitration flies in the face of both its original purpose and the complex nature of interstate territorial disputes, and examine the features that produce interstate arbitration's two-dimensional traditional nature. Chapter $\mathbf{2}$ will analyze the four case studies in accordance with the outline provided above and evaluate the extent to which the state parties' and tribunals' understanding and implementation, or lack thereof, of this twodimensional nature may have impacted the ultimate success or failure of these arbitrations. Chapter 3 will offer lessons to be learned from the case studies in the form of a preliminary framework of "best practices", intended to reinforce the traditional "true nature" of interstate arbitration and guide states and arbitral tribunal in its use for the resolution of complex interstate disputes.

\footnotetext{
${ }^{36}$ To the author's knowledge, these are also the most notable interstate territorial arbitrations that have taken place since WWII, other than the 1968 Rann of Kutch Arbitration between India and Pakistan. A detailed discussion of the latter arbitration is beyond the scope of this paper.
} 


\section{Chapter 1}

\section{Introduction to Interstate Territorial Disputes and Interstate Arbitration}

\section{Interstate territorial disputes}

Interstate territorial disputes are an unfortunate yet unavoidable aspect of international relations, and much effort has been dedicated to their peaceful resolution. ${ }^{37}$ While there is no shortage of dispute settlement alternatives designed to achieve this goal, interstate territorial disputes remain notoriously difficult to resolve effectively. ${ }^{38}$ This difficulty is arguably rooted in the complex political-legal nature ${ }^{39}$ of these disputes, which often creates a dissonance between "what is possible in theory and what states are prepared to do in practice" 40 to resolve them.

As states are territorial entities at their core, territorial sovereignty continues to be of great political importance to governments and, regardless of the origins of a particular territorial dispute, ${ }^{41}$ constitutes a strong motivation for states to resort to war. ${ }^{42}$ In addition to its "psychological importance" to states, which may be "quite out of proportion to its intrinsic value,

\footnotetext{
${ }^{37}$ Evan Luard, "Frontier Disputes in Modern International Relations" in Evan Luard, ed, The International Regulation of Frontier Disputes (New York, Washington: Praeger Publishers, 1970) at 7 [Luard]; Pan, supra note 20 at $6,19$.

${ }^{38}$ Merrills, "International Dispute Settlement", supra note 17 at 286, 290; Pan, supra note 20 at 19.

${ }^{39}$ Pinto, "Prospects", supra note 4 at 94-95; Evan Luard, "Conclusions" in Evan Luard, ed, The International Regulation of Frontier Disputes (New York, Washington: Praeger Publishers, 1970) at 223; Pan, supra note 20 at 23,31 .

${ }^{40}$ Merrills, "International Dispute Settlement", supra note 17 at 286.

${ }^{41}$ Causes of territorial disputes include, for instance, succession of states, disappearance of states, and modification of borders, Böckstiegel, supra note 5 at 43 . The two-dimensional account of arbitration proposed in this paper is intended to apply to interstate territorial disputes regardless of their underlying causes.

${ }^{42}$ According to one research, between 1945-1974, 66 interstate disputes had a clear boundary component, of which 24 involved some military action, Srecko, supra note 22 at 97 . According to another research, out of 343 interstate disputes between 1945-2003, in 78 the disputed issue related to territory, Bercovitch \& Fretter, supra note 6 at 10. Yet another research indicates that over one-quarter of all military conflicts and over half of wars between 18161992 explicitly involved territorial issues, and such issues were also found to greatly increase the probability of conflict and for such conflict to escalate, Paul R. Hensel, "Territory: Theory and Evidence on Geography and Conflict," in John A. Vasquez, ed, What Do We Know About War? (Maryland, Oxford: Rowman \& Littlefield Publishers, Inc., 2000) at 57 [Hensel], cited in The Carter Center, supra note 17 at 47-48. See also, Merrills, "International Boundary Disputes", supra note 6 at 95, 99; Malintoppi, supra note 17 at 133; Nejib Jibril, "The Binding Dilemma: From Bakassi to Badme - Making States Comply with Territorial Decisions of International Judicial Bodies" (2003-2004) 19 Am U Int'l L Rev 633 at 634 [Jibril]; Beth A. Simmons, "Capacity, Commitment, and Compliance : International Institutions and Territorial Disputes" (2002) 46 J Confl Resolution 829 at 829 [Simmons].
} 
strategic or economic", ${ }^{43}$ territory is also frequently intertwined with other interests that may have a "tangible" value, such as natural resources, or an "intangible" value, such as national identity. ${ }^{44}$ Moreover, the eruption of a territorial dispute is often rooted in its political significance within a country, the political leadership involved, and historical circumstances, ${ }^{45}$ and its resolution is therefore inevitably linked to the "traditions, interests and attitudes" of the disputing states, their relative bargaining power, and their respective regional environments. ${ }^{46}$ In many territorial disputes, national prejudices and history have frustrated parties' desire or ability to settle, ${ }^{47}$ and where the disputing states' legal cultures and technical resources are not comparable or they are of unequal political and economic influence, voluntary settlement is even less likely to occur. ${ }^{48}$ At the same time, states embroiled in territorial conflicts often have both conflicting and common interests at stake, which makes judicially imposed zero-sum solutions impracticable. $^{49}$

In addition to these strong political dimensions, many interstate territorial disputes are further complicated by legal issues, claims, and justifications, ${ }^{50}$ creating a "cocktail of political, legal and other potions". 51 Law frequently plays a significant role in defining the issues in dispute in territorial conflicts and providing a framework for negotiation or conciliation, ${ }^{52}$ and in the majority of interstate territorial disputes the parties seek to justify their position, or at least some aspect of it, on the basis of legal rights ${ }^{53}$ or legal principles designed to regulate territorial sovereignty. ${ }^{54}$ Such principles include, for instance, the uti possidetis juris principle that

\footnotetext{
${ }^{43}$ Copeland, supra note 5 at 3104; Luard, supra note 37 at 7.

${ }^{44}$ The Carter Center, supra note 17 at 46.

${ }^{45}$ Merrills, "International Dispute Settlement", supra note 17 at 289.

${ }^{46}$ Ibid at 287; John Quigley, "The Role of Law in a Palestinian-Israeli Accommodation" (1999) 31 Case W. Res. J. Int'l L. 351 at 352 [Quigley].

${ }^{47}$ Hopkinson, supra note 27 at 80.

${ }^{48}$ Francisco Orrego Vicuña \& Christopher Pinto. "Peaceful Settlement of Disputes: Prospects for the $21{ }^{\text {st }}$ Century, Revised Report Prepared for the Centennial of the First International Peace Conference" in Frits Kalshoven, ed, The Centennial of the First International Peace Conference: Reports \& Conclusions (The Hague: Kluwer Law International, 2000) 261 at 294 [Vicuña \& Pinto]; Hopkinson, supra note 27 at 82.

${ }^{49}$ Srecko, supra note 22 at 98 ; The Carter Center, supra note 17 at iii.

${ }^{50}$ Luard, supra note 37 at 11; Quigley, supra note 46 at 352-353.

${ }^{51}$ Shaw, "Political Disputes", supra note 11 at 49.

${ }^{52}$ Merrills, "International Dispute Settlement", supra note 17 at 291.

${ }^{53}$ Study Group, supra note 6 at 6, 59-60; Pan, supra note 20 at 30, 40.

${ }^{54}$ J.G. Merrills, "The Contribution of the Permanent Court of Arbitration to International Law: 1999-2009" in Belinda Macmahon \& Fedelma Claire Smith, eds, Permanent Court of Arbitration Summaries of Awards 1999-2009 (T.M.C. Asser Press, 2010) at 4 [Merrills, "PCA"].
} 
sovereignty over territory is based on previously-recognized borders; ${ }^{55}$ the principle of selfdetermination, which grants all people the right to determine their political future and freely pursue their economic, social, and cultural development; ${ }^{56}$ and the principle that states must respect the basic human rights of individuals in order to be considered as internationally legitimate. ${ }^{57}$ Although there is no clear prioritization of norms for determining territorial sovereignty under international $\operatorname{law}^{58}$ and it does not constitute the "sole or exhaustive factor" in interstate territorial disputes, it is often "an inevitable element" $" 59$ in their resolution.

Despite this complex political-legal nature of interstate territorial disputes, only "diplomatic" dispute settlement mechanisms such as negotiation, conciliation, and mediation, which are generally non-binding and are not strictly bound by legal rules and principles, are typically perceived as appropriate for their resolution. 60 "Legal" dispute settlement mechanisms, on the other hand, which are commonly understood to include arbitration and judicial settlement, are generally viewed as ill-equipped to resolve interstate territorial disputes all together, or as limited to the legal aspects of such disputes. ${ }^{61}$ The preference for "diplomatic" mechanisms in this context is arguably a result of states' reluctance to submit political or other sensitive issues to what they perceive to be binding external judgment based on legal principles. ${ }^{62}$

\footnotetext{
${ }^{55}$ In particular, this principle means that the territorial boundaries of newly-independent states remain the same as their administrative colonial borders prior to independence, The Carter Center, supra note 17 at 2-3; Pan, supra note 20 at $43-44$.

${ }^{56}$ Sebastian C. St. J. Anstis \& Mark W. Zacher, "The Normative Bases of the Global Territorial Order" (2010) 21 Diplomacy \& Statecraft 306 at 308 [Anstis \& Zacher]; Luard, supra note 37 at 14.

${ }^{57}$ Anstis \& Zacher, Ibid at 308. Other legal factors that may be relevant in determining territorial sovereignty questions are treaties and evidence of effective control, The Carter Center, supra note 17 at iii; Pan, supra note 20 at 40; Quigley, supra note 46 at 352-354.

${ }^{58}$ The Carter Center, supra note 17 at vi.

${ }^{59}$ Shaw, "Political Disputes", supra note 11 at 52.

${ }^{60}$ Munkman, supra note 6 at 5; Pan, supra note 20 at 50.

${ }^{61}$ See, e.g., Munkman, supra note 6 at 5, 12; Study Group, supra note 6 at 20; Bercovitch \& Fretter, supra note 6 at 14; Böckstiegel, supra note 5 at 43-44, 47, 49; Jeong, supra note 6 at 176; Gray \& Kingsbury, supra note 6 at 55.

${ }^{62}$ Rabow, supra note 6 at 122; McWhinney, supra note 7 at 280; Pan, supra note 20 at 2, 30.
} 
Indeed, states in modern times overwhelmingly prefer to resolve politically sensitive disputes, including territorial disputes, by employing non-binding "diplomatic" mechanisms, ${ }^{63}$ and these mechanisms undoubtedly offer advantages that judicial settlement lacks. First, they enable states to maintain their views of the facts and the law, control the terms of any settlement agreement, ${ }^{64}$ and focus on non-legal disputed issues. ${ }^{65}$ Moreover, states may prefer to resolve territorial disputes on the basis of "political wisdom", expediency, and "the lessons of political or administrative experience", rather than on the basis of law. ${ }^{66}$ Such resolution is also more likely to produce a compromise ${ }^{67}$ that is both less risky and unpredictable to the parties and more durable and stable. ${ }^{68}$

States' preference for "diplomatic" dispute settlement mechanisms to resolve complex territorial disputes, however, may also compromise their interests by causing unnecessary delay or failure to obtain an effective resolution. "Decades of political discourse" ${ }^{60}$ may prolong disputes and lead to deadlock, further conflict or conflict escalation, and potentially hinder the development of interstate relations that may ultimately be more beneficial to states than a favourable outcome in

\footnotetext{
${ }^{63}$ One research indicates that only in 6\% of territorial disputes in the Western Hemisphere between 1816-1992 involved attempts of resolution by binding third-party settlement, Hensel, supra note 42 at 75-76. Another research indicates that out of 165 interstate territorial disputes involving 1,140 rounds of negotiations between 1945-2000, 78 disputes were eventually settled by negotiations and 18 were settled by arbitration or adjudication, Paul K. Huth, Sarah E. Croco \& Benjamin J. Appel, "Bringing Law to the Table: Legal Claims, Focal Points, and the Settlement of Territorial Disputes Since 1945" (2012) 57(1) American Journal of Political Science 90 at 96 [Huth, Croco \& Appel]. Yet another research indicates that in $91.5 \%$ of 343 interstate disputes between 1945-2003, the parties resorted to mediation or negotiation, while only in $0.6 \%$ the parties resorted to arbitration, Bercovitch \& Fretter, supra note 6 at 29. See also, Vanessa Ann Lefler, Bargaining for peace? Strategic forum selection in interstate conflict management (Dissertation, University of Iowa, 2012), online: <http://ir.uiowa.edu/etd/3335> at 3-5 [Lefler]; Bercovitch \& Fretter, supra note 6 at 14; Allee \& Huth, supra note 22 at 286; Copeland, supra note 5 at 3103; Sohn, "International Security", supra note 32 at 156, 162; Merrills, "International Boundary Disputes", supra note 6 at 108; Anna Spain, "Integration Matters: Rethinking the Architecture of International Dispute Resolution" (2010) 32:1 U Pa J Int'l L 1 at 6, 10-11 [Spain, "Integration Matters"]; Malintoppi, supra note 17 at 133; Pan, supra note 20 at 3,30 .

${ }^{64}$ Study Group, supra note 6 at 38; Spain, "Integration Matters", Ibid at 6; Pan, supra note 20 at 53-54.

${ }^{65}$ The Carter Center, supra note 17 at vi, vii; Pan, supra note 20 at 54.

${ }^{66}$ Shaw, "Political Disputes", supra note 11 at 51.

${ }^{67}$ Pan, supra note 20 at 54.

${ }^{68}$ The Carter Center, supra note 17 at 17, 71.

${ }^{69}$ Study Group, supra note 6 at 39; Pan, supra note 20 at 6.

${ }^{70}$ Aman Mahray McHugh, "Resolving International Boundary Disputes in Africa: A Case for the International Court of Justice" (2005-2006) 49 Howard LJ 209 at 239 [McHugh].
} 
a particular dispute. "Diplomatic" dispute resolution mechanisms may also prove unsuccessful where the parties are "enduring rivals" and the dispute has experienced negotiation stalemate, ${ }^{72}$ and where commitment problems exist that make it difficult for either party to bind itself to an agreement. $^{73}$ These mechanisms have also proven less effective in overcoming the "critical barriers" that prevent successful resolution of territorial claims, ${ }^{74}$ such as the absence of agreedupon principles that may lead to a solution and the parties' reluctance to make concessions. ${ }^{75}$

In light of the limitations of both "diplomatic" dispute resolution mechanisms and judicial settlement in resolving complex interstate territorial disputes, a viable alternative that is capable of providing an authoritative, efficient, effective, and fair solution to both the legal and non-legal aspects of these disputes seems to be called for. Interstate arbitration arguably constitutes such an alternative, however its sui generis two-dimensional nature, which allows it to resolve complex disputes based on both law and diplomacy, has been "largely ignored" 76 in its modern “judicialized" model. ${ }^{77}$ This contemporary misperception of interstate arbitration does not only run counter to the complex political-legal nature of interstate territorial disputes described above, but also flies in the face of the original purpose and "true nature" of interstate arbitration itself. ${ }^{78}$

\section{Interstate arbitration}

\subsection{The historical origins and purpose of interstate arbitration}

The origins of arbitration can be traced back to the Greece of Aristotle and the China of Confucius, when arbitrators were arguably seen as "diplomats" of sorts rather than as strictly "judges". In those times, arbitration was distinguished from determination of disputes by judges because "an arbitrator may consider the equity of the case, whereas a judge is bound by the letter

\footnotetext{
${ }^{71}$ One research indicates that in most interstate disputes between 1945-2003 in which mediation was applied, and in almost half of such disputes in which negotiation was applied, these methods failed to resolve the dispute, Bercovitch \& Fretter, supra note 6 at 29. Another research shows that binding conflict management techniques are two to four times more likely to end a territorial claim than nonbinding mediation or bilateral negotiations, Gent $\&$ Shannon, supra note 30 at 367. See also, Study Group, supra note 6 at 39; The Carter Center, supra note 17 at v; Huth, Croco \& Appel, supra note 63 at 92.

${ }^{72}$ Huth, Croco \& Appel, Ibid at 100.

${ }^{73}$ Lefler, supra note 63 at 2.

${ }^{74}$ Gent \& Shannon, supra note 30 at 378.

${ }^{75}$ Rabow, supra note 6 at 122-123.

${ }^{76}$ Allee \& Huth, supra note 22 at 286.

77 Pinto, "Prospects", supra note 4 at 85, 94-95.

${ }^{78}$ Pinto, "The Flame Rekindled", supra note 10 at 44.
} 
of the law" ${ }^{79}$ Such "equity" was considered to include "every thing, which it is more proper to do than to omit, even beyond what is required by the express rules of justice". 80 "Compromissory clauses" providing for dispute resolution by arbitration were included in interstate treaties as far back as 418 B.C., when a treaty of peace between Sparta and Argos was concluded. Arbitration was used in those times to resolve a wide variety of interstate issues ranging from frontiers to breaches of peace by armed attack. ${ }^{81}$

The use of interstate arbitration continued during the Middle Ages, "offering the singular spectacle of conciliation and peace advancing between populations of the most warlike character". ${ }^{82}$ Arbitration was often resorted to not only to prevent wars but also to end them by utilizing both its "legal" and "diplomatic" dimensions to reconcile the parties and re-establish peace $^{83}$ in accordance with the rules of law and "in the most useful and suitable way". ${ }^{84}$

The modern era of interstate arbitration is commonly viewed as commencing with the signing of the Jay Treaty of 1794 between Great Britain and the United States, which was designed to resolve various disputes between the two countries that threatened to result in war. ${ }^{85}$ With respect to three such disputes that were not settled in the Treaty itself, including one concerning territory, it provided for resolution by a quasi-diplomatic arbitral process that combined legal proceedings and diplomatic negotiations ${ }^{86}$ and retained many of the traditional two-dimensional features of arbitration. For instance, in one of these disputes the parties were silent regarding how the arbitration commission was to decide, and it based its decision largely on equity and did not become too involved in the application of international law. ${ }^{87}$ The remaining two disputes, moreover, were explicitly to be decided according to "justice, equity and the law of nations". ${ }^{88}$

\footnotetext{
79 Pinto, "Prospects", supra note 4 at 65.

${ }^{80}$ Ibid.

${ }^{81}$ Jackson H. Ralston, International Arbitration from Athens to Locarno (California: Stanford University Press, 1929) at 157-158 [Ralston].

82 Ibid at 176.

${ }^{83}$ Ibid at 181 .

${ }^{84}$ Ibid at 180.

${ }^{85}$ Pinto, "Prospects", supra note 4 at 66.

86 The commissions were comprised solely of the parties' nationals, which some argue "encouraged a high level of consensus-seeking”, Charles H. II. Brower, "The Functions and Limits of Arbitration and Judicial Settlement Under Private and Public International Law” (2007-2008) 18 Duke J. Comp. \& Int'l L. 259 at 266, 270-271 [Brower]; Kaj Hobér, Essays on International Arbitration (Juris Publishing, Inc., 2006) at 3-4 [Hobér].

${ }^{87}$ Hobér, Ibid at 4, 8 .

${ }^{88}$ Pinto, "Prospects", supra note 4 at 85; Ralston, supra note 81 at 191-192; Hobér, Ibid at 5-6.
} 
The successful settlements achieved by some of the arbitral commissions under the Jay Treaty have largely been credited to their "spirit of negotiation and compromise" 89 and to the arbitrators acting "as negotiators rather than as judges". ${ }^{90}$ While they utilized the "legal dimension" of the arbitral process by issuing reasoned awards based on the application of legal principles, these commissions were considered to work best where "the subject-matter of the dispute allowed or encouraged the commissioners...to give a measure of satisfaction to both sides, for example, in a territorial dispute", ${ }^{91}$ since this permitted them to employ the "diplomatic dimension" of arbitration in order to produce an effective and fair outcome.

The success of these arbitrations, among others,${ }^{92}$ resulted in a steady increase in the number of interstate arbitration agreements during the nineteenth century. ${ }^{93}$ These often instructed the arbitrators to decide "according to justice" or "according to principles of justice and equity", ${ }^{94}$ thereby emphasizing their role as "diplomats" rather than "judges". Moreover, at a Conference of the Association for the Reform and Codification of the Law of Nations in 1873 it was unanimously agreed that arbitration was to be regarded "as a means essentially just and reasonable, and even obligatory on all nations, of terminating international differences which cannot be settled by negotiation". 95 At a later seating of the Conference, while defining one of the objects of the Association as "the question of International Law", it was repeated that "the principal object, nevertheless, [was] to be Arbitration as a means of settlement of all differences between nations", ${ }^{96}$ whether legal or extra-legal.

However, as this rise in prominence of interstate arbitration was essentially an "Atlantic movement" spearheaded by the states of Europe and America, it became greatly influenced by the European legal tradition and as a result gradually evolved into a search for "orderly" dispute settlement through the application of law and institutionalized "compulsory arbitration". ${ }^{97}$ This

\footnotetext{
${ }^{89}$ Pinto, "The Flame Rekindled", supra note 10 at 59.

${ }^{90}$ Pinto, "Prospects", supra note 4 at 68.

${ }^{91}$ Ibid.

${ }^{92}$ Such as the 1814 arbitrations between the United States and Great Britain under the Treaty of Ghent and the 1871 Alabama claims Arbitration under the Treaty of Washington, Pinto, "Prospects", supra note 4 at 72; Hobér, supra note 86 at 13-18; Henry T. King Jr. \& James D. Graham, "Origins of Modern International Arbitration" (1996) 12(1) Dispute Resolution Journal 42 at 46 [King \& Graham].

${ }^{93}$ Pinto, "Prospects", supra note 4 at 69-70.

${ }^{94} \mathrm{Ibid}$ at 85; Hobér, supra note 86 at 13.

${ }^{95}$ Henry Richard, "The Recent Progress of International Arbitration: A Paper" in Henry Richard, Arbitration: Two Views : The Recent Progress of International Arbitration (New York: Garland Publishing, 1971) at 2 [Richard].

${ }^{96}$ Ibid.

${ }^{97}$ Pinto, "Prospects", supra note 4 at 70-72; Pinto, "The Flame Rekindled", supra note 10 at 60.
} 
trend culminated in the 1899 Hague Peace Conference and the establishment of the Permanent Court of Arbitration ("PCA"). 98 Arguably departing from its original two-dimensional conception, the 1899 Hague Convention declared that interstate arbitration was intended to settle "questions of a legal nature, and especially...the interpretation or application of International Conventions" 99 "by judges of [states'] own choice, and on the basis of respect for law" ${ }^{100}$ This arguably implied that arbitrators were from then on to be seen as judges, and arbitral decisions as having an essentially legal nature. ${ }^{101}$ Thus began the "judicialization" process of interstate arbitration, whereby international agreements require that arbitral decisions be based strictly on applicable international law, ${ }^{102}$ and settlement incorporating "diplomatic adjustment" is viewed as impartial and fundamentally flawed. ${ }^{103}$ The one-dimensional view that only such "judicial" arbitration based on law should be "arbitration properly so called" quickly followed and has become the conventional wisdom. ${ }^{104}$

This modern "judicialized" conception of interstate arbitration, however, while perhaps introducing clarity and procedural order into the practice of arbitration, has arguably also inhibited the willingness of many states to use it in the context of complex interstate disputes ${ }^{105}$ that are not amenable to resolution based solely on legal principles. Indeed, interstate arbitration entered a period of steady decline beginning in the 1930s, and it seemed that "as the rules governing arbitration grew in comprehensiveness, completeness and legal precision, so did recourse to arbitration as a means of resolving disputes decline". ${ }^{106}$ This was arguably due to the presence of strong non-legal dimension in most interstate disputes, as well as the "antiquated"

\footnotetext{
${ }^{98}$ Even though the PCA remains an administrative institution that does not function as a traditional court and does not have compulsory jurisdiction, Pinto, "Prospects", supra note 4 at 72-73.

99 Article 16 (emphasis added), Ibid at 74.

${ }^{100}$ Article 15 (emphasis added), Ibid at 73.

${ }^{101}$ Ibid. The phrase "on the basis of respect for the law", on the other hand, arguably did "leav[e] considerable leeway for arbitrators not strictly to adhere to the provisions of the law", Hobér, supra note 86 at 25.

102 Jonathan I. Charney, "Third Party Dispute Settlement and International Law” (1998) 36 Colum J Transnat'l L 65 at 68 [Charney].

${ }^{103}$ Pinto, "The Flame Rekindled", supra note 10 at 60.

104 Ibid.

${ }^{105}$ Pinto, "Prospects", supra note 4 at 74, 87.

${ }^{106}$ Ibid at 70, 87-88; Gray \& Kingsbury, supra note 6 at 99-100; Srecko, supra note 22 at 93.
} 
and "inequitable" ${ }^{107}$ character of international law, which increasingly occupied the arbitral process, and the growing "dichotomy between international legality and justice". 108

In this way then, interstate arbitration, originally a "sensitive...if law-oriented mechanism", has been transformed into a system of "high legal refinement" and functionally "assimilate[d]" with judicial settlement, ${ }^{109}$ notwithstanding the continued separate existence of the two in their respective institutional forms, the PCA and the International Court of Justice ("ICJ"). ${ }^{110}$ Interstate arbitration appears to have gradually transitioned from a mechanism that "emphasizes settlement of a dispute" to an essentially "judicial" mechanism that "emphasizes the application of law to the dispute". 111 As a result, it has come to be treated by states with "wariness and circumspection", 112 excluding from its purview any dispute that cannot be decided strictly on the basis of law. ${ }^{113}$

Notwithstanding the relative decline in the use of interstate arbitration in the aftermath of World War II, since the 1970s it has gradually regained some of its credence with the drafting of the UNCITRAL Arbitration Rules in 1976, the creation of the Iran-United States Claim Tribunal in 1981, and the revival of the PCA during the 1990s and the first decade of the twenty-first century. ${ }^{114}$ Indeed, the range of disputes involving states that are submitted to arbitration nowadays is extremely broad, and includes disputes concerning treaty interpretation, ${ }^{115}$ maritime and fisheries, ${ }^{116}$ trade, ${ }^{117}$ diplomatic protection, ${ }^{118}$ and foreign investment. ${ }^{119}$ However, in most

\footnotetext{
${ }^{107}$ Report of the Special Committee on Principles of International Law concerning Friendly Relations and Cooperation among States, in United Nations Juridical Book, 1964, at 123, online: <http://untreaty.un.org/cod/UNJuridicalYearbook/pdfs/english/ByVolume/1964/chpIII.pdf\#page=3> [Report Friendly Relations].

${ }^{108}$ Ibid at 124.

${ }^{109}$ Pinto, "Prospects", supra note 4 at 65.

${ }^{110}$ Shabtai Rosenne, "Some Thoughts on International Arbitration Today" (1993) 27 Isr L Rev 447 at 451, 458 [Rosenne].

${ }^{111}$ Pinto, "The Flame Rekindled", supra note 10 at 60 (emphasis in the original).

${ }^{112} \mathrm{Ibid}$; Pinto, "Prospects", supra note 4 at 88.

${ }^{113}$ Hazel Fox, "Arbitration" in Evan Luard, ed, The International Regulation of Frontier Disputes (New York, Washington: Praeger Publishers, 1970) at 193 [Fox]; Charney, supra note 102 at 70.

${ }^{114}$ Howard M. Holtzmann, "The Permanent Court of Arbitration and the Evolution of a Worldwide Arbitration Culture" in The International Bureau of the Permanent Court of Arbitration, ed, International Alternative Dispute Resolution: Past, Present and Future (The Hague: Kluwer Law International, 2000) at 103-104, 109 [Holtzmann, "PCA"]; Brower, supra note 86 at 292.

${ }^{115}$ Collier \& Lowe, supra note 4 at 38; Gray \& Kingsbury, supra note 6 at 108; Louise B. Sohn, "The Role of Arbitration in Recent International Multilateral Treaties" (1982-1983) 23 Va J Int'l L 171 at 176-177 [Sohn, "Multilateral Treaties"].

${ }^{116}$ Collier \& Lowe, supra note 4 at 84; Merrills, “International Dispute Settlement”, supra note 17 at 176-179.

${ }^{117}$ Collier \& Lowe, Ibid at 96; Merrills, "International Dispute Settlement", Ibid at 213-215.

${ }^{118}$ Gideon, supra note 4 at 349-350; Gray \& Kingsbury, supra note 6 at 107.
} 
cases the issues submitted for resolution remain largely legal, and arbitrators tend to decide them as "judges" on the basis of strict application of international law rather than as "diplomats" on the basis of "justice" or "equity", thereby perpetuating the one-dimensional "judicialized" form of modern interstate arbitration. ${ }^{120}$ As the distinction between arbitration and judicial settlement continues to fade, so does the prospect of states willingly arbitrating more politically sensitive disputes. $^{121}$

That being said, this recent proliferation of arbitrations involving states may nevertheless suggest that they are increasingly willing to accept third party binding resolution in disputes that carry some political significance. This is evident, for instance, in the international investment field, where disputes often have strong political aspects, involve sovereign activities, and "stir powerful emotions", but where arbitration has thrived nonetheless. ${ }^{122}$ If this purported inclination of states is nurtured and developed to further deepen their understanding of the traditional twodimensional "essence" ${ }^{\prime 23}$ of arbitration, it may strengthen their confidence ${ }^{124}$ in its ability to resolve also highly political interstate disputes such as territorial disputes involving armed conflict.

\subsection{The "true nature" of interstate arbitration}

The original purpose and traditional nature of interstate arbitration, therefore, lies in its twodimensional nature, which enables it to provide a "genuine alternative method of dispute settlement" 125 based on both law and diplomacy. However, interstate arbitration appears to have lost this traditional quality in its contemporary form as a result of the prevalent misconception that arbitration and judicial settlement represent a "distinction without a difference". ${ }^{126}$ In order for interstate arbitration to regain its original standing as a sui generis hybrid mechanism that is capable of effectively resolving both legal and non-legal disputes, its unique two-dimensional characteristics ${ }^{127}$ should be emphasized, understood, and utilized by states. These will be set out

\footnotetext{
${ }^{119}$ Brower, supra note 86 at 292.

${ }^{120}$ Hobér, supra note 86 at 55.

${ }^{121}$ Calpham, supra note 6 at 432.

122 Brower, supra note 86 at 292-293, 298-299, 304-306.

${ }^{123}$ Pinto, "The Flame Rekindled", supra note 10 at 44.

${ }^{124}$ Werner, supra note 13 at 75.

${ }^{125}$ Pinto, "Prospects", supra note 4 at 86-87; McHugh, supra note 70 at 239.

${ }^{126}$ Pinto, "Prospects", Ibid at 87; Merrills, "International Dispute Settlement", supra note 17 at 83, 288; Vicuña \& Pinto, supra note 48 at $271,285$.

${ }^{127}$ Pinto, "The Flame Rekindled", supra note 10 at 44.
} 
and described briefly below, and examined in the context of interstate territorial disputes in the case studies analyzed in Chapter 2.

\subsubsection{Arbitration is inherently binding}

Unlike the limited enforceability of both non-binding interstate dispute settlement mechanisms and ICJ decisions, arbitration's two-dimensional nature arguably makes it inherently binding. ${ }^{128}$ While at present there is no international legal enforcement mechanism of interstate arbitral awards, they arguably exert "legal, moral and diplomatic force" ${ }^{\prime 129}$ not only because they are reasoned decisions rendered by neutral third parties and since states prefer to avoid the political and reputational costs of non-compliance, ${ }^{130}$ but also, and more importantly, because where the two-dimensional nature of arbitration is understood and applied properly, states become personally invested in the arbitral process and outcome. ${ }^{131}$ Where state parties submit all issues in dispute to arbitrators of their choosing and are provided with a just settlement that accounts for their broader relationship, underlying interests, and cultural and legal traditions, ${ }^{132}$ they are arguably more likely to develop a "shared understanding"133 of, and a "sense of commitment"134 to, the arbitral process and its outcome, and to perceive them as legitimate and binding.

Because of this inherently binding nature, moreover, arbitration can also provide a state party with legitimate "political cover"135 and protection from loss of face by allowing it to use the arbitral tribunal as a "scapegoat" 136 and thereby diffuse difficult political situations. ${ }^{137}$ As

\footnotetext{
${ }^{128}$ While Article 94 of the U.N. Charter obligates member states to comply with ICJ decisions, its inexplicit language and the Security Council's hesitation to enforce it have largely led to inaction, and it has yet to take any measures to enforce ICJ decisions based on this provision, Constanze Schulte, Compliance with Decisions of the International Court of Justice (Oxford: Oxford University Press, 2004) at 39; Jibril, supra note 42 at 659-660, 662, 668. Although there have also been cases where interstate arbitral awards have not been complied with, this paper argues that this was largely a result of the misperception and misapplication of the arbitral process.

${ }^{129}$ Malintoppi, supra note 17 at 159 . A study of the execution of 300 arbitral awards between 1794-1936 found only 20 cases of non-compliance, Richard B. Bilder, "Adjudication: International Arbitral Tribunals and Courts" in I. William Zartman, ed, Peacemaking in International Conflict: Methods \& Techniques (Washington, D.C.: United States Institute of Peace, 2007) at 200.

${ }^{130}$ Merrills, "International Dispute Settlement", supra note 17 at 114, 293; Simmons, supra note 42 at 835 ; Gent \& Shannon, supra note 30 at 368; Bercovitch \& Fretter, supra note 6 at 27.

131 Jibril, supra note 42 at 668.

132 Pan, supra note 20 at 61.

${ }^{133}$ Jutta Brunnée and Stephen J. Toope, "Constructivist Approaches to International Law" in Jeffrey L. Dunoff \& Mark A. Pollack, eds, Interdisciplinary Perspectives on International Law and International Relations: The State of the Art (Cambridge University Press, 2012) at 135 [Brunnée \& Toope].

${ }^{134}$ Ibid at 134.

135 Allee \& Huth, supra note 22 at 300-301; Gent \& Shannon, supra note 30 at 369.

${ }^{136}$ Lachs, "Arbitration and International Adjudication", supra note 17 at 40; Malintoppi, supra note 17 at 133.

${ }^{137}$ Corell, supra note 27 at 34.
} 
governments are often reluctant to agree to negotiated settlements or make voluntary concessions due to domestic political constraints, ${ }^{138}$ arbitration can be used to justify such concessions domestically $^{139}$ as well as legitimize the successful state's claim in the eyes of the international community. ${ }^{140}$ In this way, arbitration can be used strategically to achieve an outcome that cannot be obtained through negotiation, ${ }^{141}$ and can play an important role in facilitating a longterm settlement by providing a binding and neutral decision. ${ }^{142}$ Arbitration is therefore particularly useful where a fundamental lack of trust between the parties influences their behavior or claims. ${ }^{143}$ In such circumstances, the parties may not be able to negotiate in good faith because of mutual distrust, and a diplomatic, yet binding, resolution provided by a neutral third party may supply the missing element of objectivity and impartiality, resulting in a mutually acceptable outcome.

\subsubsection{Arbitration is flexible}

Procedural and substantive flexibility is fundamental to the two-dimensional nature of interstate arbitration. First, unlike the largely fixed composition of a permanent court or tribunal, ${ }^{144}$ in arbitration state parties are free to choose their decision makers. ${ }^{145}$ This allows them to appoint arbitrators with specific non-legal expertise, or who are familiar with the dispute and the parties' interests, and is likely to inspire greater confidence in the arbitral tribunal. ${ }^{146}$ Indeed, the right of parties to choose their arbitrators is viewed as "a right which is of the very essence of arbitral justice". ${ }^{147}$ This right is particularly significant in territorial disputes, moreover, as these are

\footnotetext{
${ }^{138}$ Gent \& Shannon, supra note 30 at 369-370; Merrills, "International Dispute Settlement", supra note 17 at 111.

139 Allee \& Huth, supra note 22 at 300-301; Simmons, supra note 42 at 834; Bercovitch \& Fretter, supra note 6 at 27.

${ }^{140}$ Bercovitch \& Fretter, Ibid at 27.

141 Simmons, supra note 42 at 831.

${ }^{142}$ Gent \& Shannon, supra note 30 at 369-370; Merrills, "International Dispute Settlement", supra note 17 at 111.

${ }^{143}$ Vaughan Lowe, "Is There a Role for International Law in the Middle East Peace Process?", Comments from ASIL proceedings, 2005, 99 Am Soc'y Int'l L Proc 213 at 221.

${ }^{144}$ Vicuña \& Pinto, supra note 48 at 290-291. Although a party to an ICJ case that does not have a judge of its nationality on the bench may appoint an ad hoc judge to sit for the duration of the case, ICJ statute, Art. 31(3), Ruth Mackenzie, et al, "The Manual on International Courts and Tribunals", 2nd ed (Oxford: Oxford University Press, 2010) at 7-8 [Mackenzie, et al]; Howard M. Holtzmann, "Some Reflections on the Nature of Arbitration" in Sam Muller and Wim Mijs, eds, The Flame Rekindled: New Hopes for International Arbitration (The Netherlands: Martinus Nijhoff Publishers, 1994) at 73 [Holtzmann, "Reflections"].

${ }^{145}$ D.H.N. Johnson, "International Arbitration Back in Favour?" (1980) 34 Yearbook of World Affairs 305 at 306307 [Johnson, "Back in Favour']; Gray \& Kingsbury, supra note 6 at 111-112; Malintoppi, supra note 17 at 141.

146 Johnson, "Back in Favour", Ibid at 312; Merrills, "International Dispute Settlement", supra note 17 at 111.

147 Pinto, "The Flame Rekindled", supra note 10 at 47.
} 
frequently rooted in local history and should ideally be dealt with by arbitrators who appreciate the local circumstances and the relevant legal and cultural norms. ${ }^{148}$

Second, the two-dimensional nature of the arbitral process makes it more flexible and informal than judicial settlement, ${ }^{149}$ while still guaranteeing the parties procedural fairness and safeguards. Flexibility is particularly important in interstate territorial disputes, which states often need to resolve quickly since the certainty and stability of international boundaries is essential for economic development and exploitation of natural resources. ${ }^{150}$ Therefore, the ICJ's cumbersome and lengthy procedures ${ }^{151}$ arguably make it a particularly unattractive forum for the resolution of such disputes. ${ }^{152}$ Moreover, the two-dimensional arbitral process can better accommodate cases requiring fact finding or settlement based on extra-legal principles, as territorial disputes often do. ${ }^{153}$ Such disputes are usually governed by "a few basic legal principles" that must be weighed against dominant "physical, mathematical, historical, political, economic or other facts", ${ }^{154}$ and would therefore benefit from a more flexible and less legally rigid dispute resolution mechanism. ${ }^{155}$

Third, where state parties properly utilize the two-dimensional nature of arbitration, they are able to retain more control over the course of the arbitral process, ${ }^{156}$ since they are able to draw up their own arbitration agreement, or compromis, and decide on the procedural and substantive rules to be applied by the tribunal. ${ }^{157}$ This includes such matters as the place of the arbitration, costs, evidentiary issues, whether the arbitration proceedings are to be held in private, and

\footnotetext{
${ }^{148}$ Srecko, supra note 22 at 96; Pan, supra note 20 at 60.

149 The Carter Center, supra note 17 at vi-vii.

${ }^{150}$ Srecko, supra note 22 at 90.

${ }^{151}$ Mackenzie, et al, supra note 144 at 37; Ernst-Ulrich Petersmann, "Proposals for Strengthening the UN Dispute Settlement System" (1999) 3 Max Planck UNYB 105 at 121 [Petersmann].

152 The ICJ has issued decisions in only 14 cases involving land territory, The Carter Center, supra note 17 at 2.

${ }^{153}$ Collier \& Lowe, supra note 4 at 33; The Carter Center, supra note 17 at vii; Mackenzie, et al, supra note 144 at 37. While the ICJ has at times broadened the basis of its decisions by taking into account such considerations as cultural diversity and changing circumstances, and refining the law accordingly, the demands of legal continuity arguably impose limits on this ability of the Court, which do not exist in arbitration, Merrills, "International Dispute Settlement", supra note 17 at 147.

${ }^{154}$ Srecko, supra note 22 at 99.

155 Some scholars have therefore called for territorial disputes involving "sensitive issues of political and nationalistic concern" to be referred to arbitration, Jibril, supra note 42 at 668 . See also, Merrills, "International Boundary Disputes", supra note 6 at 102; Pan, supra note 20 at 60.

${ }^{156}$ Gideon, supra note 4 at 348; Gray \& Kingsbury, supra note 6 at 109; Merrills, "International Dispute Settlement", supra note 17 at 111; Vicuña \& Pinto, supra note 48 at 290.

${ }^{157}$ Merrills, "International Dispute Settlement", supra note 17 at 83, 89; Malintoppi, supra note 17 at 143.
} 
whether the award shall remain confidential. ${ }^{158}$ Perhaps most importantly, the parties also decide on the issues and questions to be referred to the arbitral tribunal for determination, which may be legal or extra-legal, and establish its mandate and jurisdiction. ${ }^{159}$ The issues and questions to be submitted to arbitration may not always be agreed upon by the parties, and in such circumstances they may leave these to be determined by the arbitral tribunal. ${ }^{160}$

\subsubsection{Arbitration is not a strictly "legal" process}

As its two-dimensional traditional nature suggests, the role of law in interstate arbitration is different from its role in judicial settlement, which is intended to resolve disputes "in strict accordance with international law". ${ }^{161}$ While arbitration and ICJ litigation share a "legal dimension" since they are both intended to produce procedurally fair and reasoned decisions and presuppose a legal obligation by the parties to accept them, ${ }^{162}$ arbitration envisages a more flexible, contextual, and broad interpretation and application of legal rules and principles by the arbitrators. In addition, arbitration involves an additional "diplomatic dimension" entirely absent from ICJ litigation, which assigns to law a "basic but by no means exclusive function"; ${ }^{163}$ permits decisions ex aequo et bono unless explicitly excluded by the parties; ${ }^{164}$ and allows arbitrators to act as "diplomats" in addition to "judges".

Arbitrators are therefore not as concerned with "stat[ing] the law" and settling the dispute by "strict application of the legal rules" 165 as they are with "reconcil[ing] national interests", "eas[ing] the tensions and encourage[ing] the re-building and development of lasting cooperation", and achieving an "acceptable settlement", ${ }^{166}$ all of which are necessary where a

\footnotetext{
${ }^{158}$ Collier \& Lowe, supra note 4 at 33-34; Gray \& Kingsbury, supra note 6 at 110-111; Gernot Biehler, Procedures in International Law (Berlin: Springer-Verlag, 2008) at 307 [Biehler]; Malintoppi, supra note 17 at 140, 143; McHugh, supra note 70 at 230. The parties may devise their own procedural rules, adopt a set of rules such as the UNCITRAL Arbitration Rules or the Optional Rules of the Permanent Court of Arbitration for Arbitrating Disputes between States, or allow the arbitral tribunal to adopt its own rules, Malintoppi, Ibid at 154.

${ }^{159}$ Merrills, “International Dispute Settlement", supra note 17 at 90-91; Malintoppi, supra note 17 at 143, 147-148; Fox, supra note 113 at $170-171$.

${ }^{160}$ Merrills, "International Dispute Settlement", supra note 17 at 91; Malintoppi, supra note 17 at 148, 150.

${ }^{161}$ Pinto, "Prospects", supra note 4 at 73, 76-77.

${ }^{162}$ Copeland, supra note 5 at 3074-3075.

${ }^{163}$ Pinto, "The Flame Rekindled", supra note 10 at 49.

${ }^{164}$ Ibid.

165 Jean-Pierre Queneudec, "The Eritrea-Yemen Arbitration: Its Contribution to International Law" in Bette Shifman, ed, The Eritrea-Yemen Arbitration Awards 1998 and 1999 (T.M.C. Asser Press, 2005) at 5-6 [Queneudec].

${ }^{166}$ Pinto, "The Flame Rekindled", supra note 10 at 49-50.
} 
dispute involves more than merely legal questions. ${ }^{167}$ On the other hand, judicial settlement by ICJ judges commonly involves a strict application of the law, ${ }^{168}$ which is likely to produce decisions that are "less persuasive to the layman or the politician", 169 arguably making it "poorly equipped to resolve complex, multi-issue disputes involving political, social, environmental, and ethical interests". 170

Arbitration and ICJ litigation also differ in their fundamental function and purpose in the international system. Litigation before the ICJ is arguably a one-dimensional process, intended to resolve "purely legal" disputes, produce decisions that would be accepted worldwide, and create the "continuity required for the consistent and progressive development of international law". 171 The ICJ's "emphasis on systematic development of jurisprudence", moreover, means that it "may not address or resolve the political dimensions of cases". ${ }^{172}$ Arbitration, on the other hand, at least as originally conceived, is intended to be a two-dimensional ad hoc process carried out by tribunals with no continued existence, no capacity to affect third parties, and tasked solely with resolving the particular dispute before them, whether legal or political. ${ }^{173}$ Therefore, “arbitration's capacity to focus on the immediate needs of parties" may be more appealing to states "locked in disputes over grave issues" 174 or "disputes involving high stakes, matters of political principle, or broad legal standards subject to a controversial range of application, ${ }^{175}$ than "the broader orientation of judicial settlement". ${ }^{176}$

\subsubsection{Arbitration is designed to achieve a fair compromise}

States that agree to resolve a dispute by arbitration arguably signal their desire to "reduce tensions" and obtain a peaceful settlement from an authoritative and independent third party. ${ }^{177}$

\footnotetext{
${ }^{167}$ Johnson, "Back in Favour", supra note 145 at 311. It should be noted that the ICJ has been increasingly prepared to hear politically charged disputes and "depoliticize" them by separating the legal aspects of the case from the political. However, this arguably risks neglecting a party's non-legal interests, which may result in the rejection of judicial decisions by losing parties. Merrills, "International Dispute Settlement", supra note 17 at 155-156; Shaw, "Political Disputes", supra note 11 at 60-62.

${ }^{168}$ Shaw, "Political Disputes", Ibid at 53.

${ }^{169}$ Lachs, "Arbitration and International Adjudication", supra note 17 at 41, cited in Chapman, supra note 4 at 88.

${ }^{170}$ Spain, "Integration Matters", supra note 63 at 16.

${ }^{171}$ Brower, supra note 86 at 293-294.

172 Ibid at 309.

${ }^{173}$ Ibid at 295.

${ }^{174}$ Ibid at 308.

175 Ibid at 298.

${ }^{176}$ Ibid at 296.

${ }^{177}$ Merrills, "International Dispute Settlement", supra note 17 at 160-161; Gent \& Shannon, supra note 30 at 368.
} 
While this may be achieved to some extent also through judicial settlement, arbitration, due to its "diplomatic dimension" and the unique role of arbitrators as "diplomats", can arguably produce a more just and pragmatic solution that avoids a "winner-takes-all" outcome. ${ }^{178}$ Moreover, arbitration is more likely to generate among disputing parties a sense of "having been treated fairly", ${ }^{179}$ and may make the process appear less risky for states engulfed in disputes involving political or vital interests. ${ }^{180}$ This, in turn, may strengthen states' willingness to agree to a binding third-party dispute resolution process in the first place, as well as improve the prospects of successful implementation of the decision.

These unique two-dimensional features of interstate arbitration, which are the foundation of its traditional sui generis nature, arguably make it best-suited for the resolution of interstate territorial disputes involving issues of "important domestic political implications". ${ }^{181}$ This is further supported by the fact that purely "diplomatic" mechanisms may be less likely to "foster lasting peace" ${ }^{, 182}$ absent a binding and authoritative award, ${ }^{183}$ and that the ICJ remains a "method of last resort" in most interstate disputes ${ }^{184}$ and politically-charged territorial disputes "will not come before [it]". ${ }^{185}$

The cases analyzed in Chapter 2 are intended to assess the extent to which these two-dimensional features of traditional interstate arbitration have been recognized by states and arbitral tribunals in past interstate territorial arbitrations, and to consider how and why such recognition, or lack thereof, may have impacted the ultimate resolution of these disputes. This analysis is also intended to form the foundation for a preliminary operational framework, set out in Chapter 3, designed to guide states and arbitral tribunals in the future use of two-dimensional arbitration to effectively resolve complex intestate disputes.

\footnotetext{
${ }^{178}$ Merrills, "International Dispute Settlement", supra note 17 at 291; Lachs, "Arbitration and International Adjudication", supra note 17 at 41.

${ }^{179}$ Lachs, "Arbitration and International Adjudication", Ibid at 41, cited in Chapman, supra note 4 at 88.

${ }^{180}$ Merrills, "International Dispute Settlement", supra note 17 at 291.

${ }^{181}$ Vicuña \& Pinto, supra note 48 at 346-347.

${ }^{182}$ Lefler, supra note 63 at 3.

${ }^{183}$ Study Group, supra note 6 at 127.

${ }^{184}$ Spain, "Integration Matters", supra note 63 at 20.

${ }^{185}$ The most common category of cases to be successfully decided by the ICJ is "the rather non political territorial demarcations which have not led to a full-blown dispute between states", Biehler, supra note 158 at 280, 285. See also, Andrew L. Mollel, "Judicial Settlement of Armed Conflicts in International Law: Reflecting the 2005 International Court of Justice Decision in the Democratic Republic of Congo" (2007) 76 Nordic J Int'l L 407 at 433 [Mollel].
} 


\section{Chapter 2}

\section{Interstate Territorial Disputes Involving Armed Conflict- Case Studies}

\section{The Beagle Channel Arbitration, 1977}

\subsection{Background}

The Beagle Channel ("Channel”), a narrow passageway connecting the Atlantic and Pacific oceans at the southern tip of South America, was the subject of a protracted dispute between Chile and Argentina since its discovery in $1830 .{ }^{186}$ In 1881 , the two countries signed a Boundary Treaty ("Treaty"), which defined in its Article III the parties' territorial entitlements in the Channel area as follows: ${ }^{187}$

...Tierra del Fuego...shall be Chilean on the western side and Argentine on the eastern. As for the islands, to the Argentine Republic shall belong Staten Island, the small islands next to it, and the other islands there may be on the Atlantic to the east of Tierra del Fuego and of the eastern coast of Patagonia; and to Chile shall belong all the islands to the south of Beagle Channel up to Cape Horn, and those there may be to the west of Tierra del Fuego.

However, the Treaty left the Channel itself undefined geographically, and since not all the surrounding islands were clearly "east of Tierra del Fuego" or "south of the Beagle Channel", ${ }^{188}$ the dispute between the parties over the area persisted. It extended to issues concerning maritime boundaries, sovereignty over certain islands located in the Channel, and associated rights, that negotiations lasting for almost a century failed to resolve. ${ }^{189}$

These ancillary issues, moreover, were of great importance to the parties for several reasons. First, both parties feared being cut off from use of the Channel and thereby having their access to the Pacific or Atlantic Ocean limited. Second, the islands of the Channel had strategic

\footnotetext{
${ }^{186}$ Friedrich Kratochwil, Paul Rohrlich \& Arpreet Mahajan, Peace and Disputed Sovereignty: Reflections on Conflict Over Territory (Lanham, MD: University Press of America, 1985) at 73 [Kratochwil, Rohrlich \& Mahajan]; Malcolm Shaw, "The Beagle Channel Arbitration Award" (1978) 6(2) International Relations 415 at 416 [Shaw, "Beagle Channel"].

${ }^{187}$ This was the English translation used by the arbitral tribunal, Argentina v Chile (1977), Decision of the Court of Arbitration, 17:3 ILM 634, at para. 15 [Beagle Channel Decision]; David M. Himmelreich, "The Beagle Channel Affair: A Failure in Judicial Persuasion" (1979) 12 Vand J Transnat'l L 971 at 975 [Himmelreich].

${ }^{188}$ Kratochwil, Rohrlich \& Mahajan, supra note 186 at 71.

${ }^{189}$ Kratochwil, Rohrlich \& Mahajan, Ibid at 71; The Carter Center, supra note 17 at 21.
} 
significance to Argentina since they were located at the entrance to one of its naval bases. Third, ownership of the islands influenced the parties' respective shares of the continental shelf, which was potentially oil and mineral bearing, and also defined their respective shares of the economic zone, which contained important fish reserves. Finally, ownership of the Channel could also affect the parties' territorial claims in Antarctica. ${ }^{190}$ In 1952, Argentina rejected an ICJ ruling awarding control of the Channel to Chile, and civilian and military occupation of the Channel remained a source of contention for the next two decades. ${ }^{191}$

\subsection{The arbitration agreement and procedure}

In 1971, Chile and Argentina signed a compromis, agreeing to arbitrate their dispute in accordance with the General Treaty of Arbitration they had signed in 1902, which provided for arbitration by the Britannic Majesty's Government of any disputes arising out of the 1881 Treaty. ${ }^{192}$ The British Government appointed a five-member arbitral tribunal composed of the following ICJ judges: Dillard (U.S.A.), Fitzmaurice (Britain), Gros (France), Onyeama (Nigeria), and Petren (Sweden). ${ }^{193}$ This procedure departed from that of previous arbitrations between Argentina and Chile pursuant to the General Treaty of Arbitration, ${ }^{194}$ in which the tribunals had included only British members. The decision to appoint ICJ judges was intended to ensure that the decision would be based on strict international legal criteria and would be perceived by the parties as objective. From its inception, therefore, the arbitration process "militated against any approach other than a strictly legal one". ${ }^{195}$

As the parties could not agree on a common question to put before the arbitral tribunal in the compromis, they each formulated a separate question. ${ }^{196}$ The Argentine question read as follows:

\footnotetext{
${ }^{190}$ Shaw, "Beagle Channel", supra note 186 at 416-417; Kratochwil, Rohrlich \& Mahajan, supra note 186 at 76; Mark Laudy, "The Vatican Mediation of the Beagle Channel Dispute: Crisis Intervention and Forum Building" in Melanie C. Greenberg, John H. Barton \& Margaret E. McGuinness, eds, Words Over War: Mediation and Arbitration to Prevent Deadly Conflict (Oxford: Rowman \& Littlefield Publishers, Inc., 2000) at 298 [Laudy]; Himmelreich, supra note 187 at 971.

${ }^{191}$ Bercovitch \& Fretter, supra note 6 at 126.

${ }^{192}$ Agreement for Arbitration (Compromiso) of a Controversy Between the Argentine Republic and the Republic of Chile Concerning the Region of the Beagle Channel, July 22, 1971, 66 Am J Int'l L 461 at Preamble [Beagle Channel compromis].

${ }^{193}$ Ibid.

${ }^{194}$ The Cordillera of the Andes Boundary case of 1902 and the Argentine-Chile frontier case of 1966, Shaw, "Beagle Channel", supra note 186 at 415, 417.

${ }^{195}$ Shaw, "Beagle Channel", Ibid at 417.

${ }^{196}$ F.V., "The Beagle Channel Affair" (1977) 71:4 Am J Int'l L 733 at 735 [F.V.].
} 
The Argentine Republic requests the Arbitrator to determine what is the boundary-line between the respective maritime jurisdictions of the Argentine Republic and of the Republic of Chile...within the region referred to in paragraph (4) of this article, and in consequence to declare that Picton, Nueva and Lennox Islands and adjacent islands and islets belong to the Argentine Republic, ${ }^{197}$

While the Chilean question read as follows:

The Republic of Chile requests the Arbitrator to decide, to the extent that they relate to the region referred to in paragraph (4) of this article, the questions referred to in her Notes of 11th December 1967 to Her Britannic Majesty's Government and to the Government of the Argentine Republic and to declare that Picton, Lennox and Nueva Islands, the adjacent islands and islets, as well as the other islands and islets whose entire land surface is situated wholly within the region referred to in paragraph (4) of this article, belong to the Republic of Chile. ${ }^{198}$

Article I(4) of the compromis included the geographical coordinates of six points that defined the zone subject to the arbitration, known as "the Hammer" due to its shape. ${ }^{199}$ This zone included the eastern part of the Beagle Channel and the territory adjoining it in the north and south, and three islands located at the eastern end of the Channel: Nueva, Picton, and Lennox ("PNL group"). ${ }^{200}$ The arbitral tribunal was to decide the case "in accordance with the principles of international law" 201 and transmit the award to the British Government for ratification. ${ }^{202}$ Once the award was ratified by the British government, it was to be considered as final ${ }^{203}$ and legally binding $^{204}$ on the parties and no appeal from it was permitted. ${ }^{205}$

\subsection{The parties' claims}

The main issue in dispute, as separately framed by each party in the compromis, was the legal ownership of the PNL group and the scope of maritime sovereignty associated with it. Both Argentina and Chile relied in their arguments on the legal interpretation of the 1881 Treaty and the application of international law principles, ${ }^{206}$ thereby arguably focusing almost exclusively

\footnotetext{
${ }^{197}$ Beagle Channel compromis, supra note 192 at Article I(1).

${ }^{198}$ Ibid at Article I(2).

${ }^{199}$ Beagle Channel Decision, supra note 187 , at para. 1.

${ }^{200}$ Shaw, "Beagle Channel", supra note 186 at 415.

${ }^{201}$ Beagle Channel compromis, supra note 192 at Article I(7).

${ }^{202}$ Ibid at Article XII(1), XIII(1).

${ }^{203}$ Ibid at Article XIII(1).

${ }^{204}$ Ibid at Article XIV

205 Ibid.

${ }^{206}$ F.V., supra note 196 at 737.
} 
on the "legal dimension" of the arbitral process. The arbitral tribunal was to determine, among other terms, the meaning of "to the south of Beagle Channel" in Article III of the Treaty, ${ }^{207}$ which determination was complicated by the fact that at a certain geographical point the Channel split into two "arms". One "arm" extended eat-south-east, passing north of Picton Island, and was considered by Chile to be the true course of the Channel, and the second extended west-east, passing south-west of Picton Island, and was considered by Argentina to be the true course of the Channel. ${ }^{208}$ Determining which "arm" in fact constituted the natural extension of the Channel would therefore determine what islands lay "to the south" of it and which country owned them.

Argentina argued that the parties had agreed in Articles I and II ${ }^{209}$ of the Treaty (the "Compromise") that Chile would receive the whole of the straits of Magellan in return for recognizing Argentine sovereignty over the Atlantic coast (the "Magellan-Atlantic" aspect of the Compromise). ${ }^{210}$ Argentina therefore adopted a "maritime" 211 approach to the dispute, and, based on the international legal doctrine of uti possidetis, ${ }^{212}$ argued that Article III of the Treaty should be interpreted in accordance with the "Oceanic" principle ${ }^{213}$ to mean that the Atlantic islands, which included the PNL group, belonged to Argentina, and the Pacific ones to Chile. ${ }^{214}$ Argentina claimed that this interpretation was further supported by the parties' intention to divide the islands south of Tierra del Fuego along the Cape Horn meridian, which geographically divided the Atlantic and Pacific oceans. ${ }^{215}$ Finally, Argentina argued that the phrase "other islands there may be on the Atlantic" in Article III must be interpreted as referring to the PNL group in order to give effect to the Treaty, as these were the only islands remaining in the area. ${ }^{216}$

\footnotetext{
${ }^{207}$ Beagle Channel Decision, supra note 187 at paras. 3, 17.

${ }^{208}$ Ibid at para. 4.

209 Article I established the north-south boundary between the two states and Article II defined the boundary between them north of the Magellan Straits, Shaw, "Beagle Channel", supra note 186 at 422, footnote 27.

${ }^{210}$ Kratochwil, Rohrlich \& Mahajan, supra note 186 at 74; Shaw, "Beagle Channel”, Ibid at 422-423.

${ }^{211}$ Beagle Channel Decision, supra note 187 at para. 6.

${ }^{212}$ According to this doctrine, "all territory in Spanish-America...is deemed to have been part of one of the former administrative divisions of Spanish colonial rule" and "the title to any given locality is deemed to have become automatically vested in whatever Spanish-American State inherited or took over the former Spanish administrative division in which the locality concerned was situated", Beagle Channel Decision, supra note 187 at para. 10.

${ }^{213}$ According to this principle, "each Party had a sort of primordial or a priori right to the whole of-and to anything situated on-in the case of Argentina, the Atlantic coasts and seaboard of the continent, and in the case of Chile the Pacific", Beagle Channel Decision, Ibid at paras. 21-22, 60; The Carter Center, supra note 17 at 21; Kratochwil, Rohrlich \& Mahajan, supra note 186 at 73; F.V., supra note 196 at 736.

${ }^{214}$ Kratochwil, Rohrlich \& Mahajan, supra note 186 at 74; F.V., supra note 196 at 736; Shaw, "Beagle Channel”, supra note 186 at 424.

${ }^{215}$ Himmelreich, supra note 187 at 977.

${ }^{216}$ Beagle Channel Decision, supra note 187 at para. 60; Ibid at 975.
} 
Chile, on the other hand, argued that the Compromise contained in Articles I and II of the Treaty expressed the parties' agreement that Chile would receive the whole of the straits of Magellan in return for renouncing its claims to the Patagonian coast east of the Andes and south of the Rio Negro (the "Patagonian-Magellan" aspect of the Compromise). ${ }^{217}$ Chile therefore adopted a "territorial" 218 approach to the dispute, and objected to the application of the uti possidetis doctrine and the Oceanic principle advocated by Argentina in light of the impossibility of its implementation due to the lack of a vertical boundary that would make the east-west principle workable. ${ }^{219}$ It claimed, instead, that the uti possidetis doctrine was replaced by the terms of the 1881 Treaty, ${ }^{220}$ and that, as the PNL group was located to the south of the Channel it belonged to Chile in accordance with Article III. ${ }^{221}$ Moreover, Chile argued that it had exercised effective sovereignty over the PNL group for many years, and therefore claimed possession over it on the basis of customary principles of international law. ${ }^{222}$ Finally, Chile argued that Argentina's interpretation of the 1881 Treaty should be rejected on the basis of the latter's post-Treaty conduct and its acceptance of various maps recognizing Chile’s claims. ${ }^{223}$

\subsection{The arbitral tribunal's decision making process}

The tribunal's decision comprised of two main parts, the first dealing with the interpretation of the 1881 Treaty and the second, considerably shorter part, dealing with "corroborative or confirmatory incidents and material". ${ }^{224}$ Similarly to the parties' arguments, the arbitrators also focused on the "legal dimension" of the arbitration and their role as "judges". While the arbitrators considered certain extra-legal factors, they ultimately based their decision on the narrow legal interpretation of the treaty.

In the first part of its decision, the arbitral tribunal adopted the Chilean approach to the interpretation of the Compromise contained in Articles I and II, finding that the PatagonianMagellan aspect of the Compromise constituted the "fundamental element of the Treaty

\footnotetext{
${ }^{217}$ Kratochwil, Rohrlich \& Mahajan, supra note 186 at 74; Shaw, "Beagle Channel”, supra note 186 at $422-423$.

${ }^{218}$ Beagle Channel Decision, supra note 187 at para. 6.

${ }^{219}$ Beagle Channel Decision, Ibid at para. 62; Laudy, supra note 190 at 296; Shaw, "Beagle Channel", supra note 186 at 425.

${ }^{220}$ Beagle Channel Decision, Ibid at para. 21.

${ }^{221}$ Laudy, supra note 190 at 296; Shaw, "Beagle Channel”, supra note 186 at 425.

${ }^{222}$ Kratochwil, Rohrlich \& Mahajan, supra note 186 at 75.

${ }^{223}$ Beagle Channel Decision, supra note 187 at para. 167; Kratochwil, Rohrlich \& Mahajan, supra note 186 at 75.

${ }^{224}$ F.V., supra note 196 at 738; Shaw, "Beagle Channel”, supra note 186 at 420.
} 
settlement" and that all other elements were secondary to it. ${ }^{225}$ Accordingly, the tribunal proceeded to reject the Oceanic principle invoked by Argentina, agreeing with Chile that the regime established in the Treaty governed the parties' territorial claims and rights to the exclusion of the uti possidetis doctrine. ${ }^{226}$

Turning to the interpretation of Article III of the Treaty, which allocated to Argentina the islands "on the Atlantic, to the East of Tierra del Fuego and of the eastern coast of Patagonia", the tribunal again favoured the Chilean approach as being the more "normal and natural", 227 finding that this article did not contain any overriding principle that the whole of the Atlantic coast was to be Argentine. Rather, it merely provided that "any 'Atlantic' motivations are...to be given effect to only in respect of the individual Articles that clearly show this intention by reason of their method of drafting or content". 228 The tribunal found that Article III did not contain this feature $^{229}$ and therefore concluded that the PNL group could not be considered as Argentine. ${ }^{230}$

The tribunal then proceeded to consider Chile's claims in light of the provision in Article III that "to Chile shall belong all the islands to the south of Beagle Channel up to Cape Horn". The tribunal found that the meaning of this phrase was to be determined in accordance with the intention of the drafters of the Treaty, and considering that the Treaty allocated all of the islands to one party only, it concluded that no other provision in the Treaty pertained to the PNL group $^{231}$ and that external evidence failed to furnish a "certain result". ${ }^{232}$ The tribunal held that the "Treaty arm", i.e., the "arm" of the Channel contemplated by the drafters of the Treaty, ${ }^{233}$ must be interpreted so as to give meaning to the term "south of" in Article III ${ }^{234}$ and in light of the fact that the drafters had failed to define the Channel's boundary and therefore that it must

\footnotetext{
${ }^{225}$ Beagle Channel Decision, supra note 187 at para. 31; Kratochwil, Rohrlich \& Mahajan, supra note 186 at 74; Himmelreich, supra note 187 at 978-979. This characterization of the parties' Compromise has been criticized as “operat[ing] against Argentina's claims", Shaw, "Beagle Channel”, supra note 186 at 423.

${ }^{226}$ Beagle Channel Decision, supra note 187 at paras. 11, 66, 74. The decision to entirely exclude the uti possidetis principle has been criticized since, where treaty interpretation is involved, this principle "can provide a useful guide to the background circumstances, elucidating presumptions and establishing a framework", Shaw, "Beagle Channel", Ibid at 421-422.

${ }^{227}$ Beagle Channel Decision, Ibid at para. 64; Shaw, "Beagle Channel", Ibid at 425; Himmelreich, supra note 187 at 978.

${ }^{228}$ Beagle Channel Decision, Ibid at para. 66.

${ }^{229}$ Ibid.

${ }^{230} \mathrm{Ibid}$ at para. 79.

${ }^{231}$ Himmelreich, supra note 187 at 980.

${ }^{232}$ Beagle Channel Decision, supra note 186 at para. 91.

${ }^{233}$ Ibid at para. 86; F.V., supra note 196 at 738.

${ }^{234}$ Himmelreich, supra note 187 at 980.
} 
have been "obvious". ${ }^{235}$ The tribunal accordingly concluded that this boundary, "as a matter of compelling probability", 236 should be considered to be the Channel's northern arm, which passed north of Picton Island. ${ }^{237}$ Consequently, the PNL group was located "south of the Channel" and therefore belonged to Chile in accordance with Article III. ${ }^{238}$

In the second part of its decision, dealing with "corroborative or confirmatory incidents and material", the tribunal considered several matters which, while expressly not constituting the basis for its conclusions, did confirm them in its view. ${ }^{239}$ First, the tribunal examined the conduct of the parties between 1881-1888, including notes, comments, and speeches made by Argentine Ministers shortly after the signing of the Treaty, which it considered to indicate their respective interpretations of the Treaty. ${ }^{240}$ Based on this analysis the tribunal concluded that Argentina's position in the arbitration was not consistent with its position when the Treaty was drawn up, while the Chilean position was. ${ }^{241}$ Second, the tribunal studied several maps of the disputed area, emphasizing that its decision regarding the PNL group was made independently of cartography although it may contribute to the ordinary processes of interpretation. ${ }^{242}$ The tribunal discarded early explorers' maps as being inconclusive, and noted that on a map given to the British diplomatic representative in Argentina in $1881,{ }^{243}$ and on an official Argentine map of 1882, the disputed area was attributed to Chile. ${ }^{244}$ Finally, the tribunal recognized the peaceful, uninterrupted, and undisputed possession of the PNL group by Chile to be a relevant consideration, ${ }^{245}$ although "in no sense a source of independent right". ${ }^{246}$ The tribunal found that certain acts of jurisdiction, such as establishing a land lease system and providing public services, performed by Chile from 1892 onwards, and Argentina's failure to react to such acts, ${ }^{247}$

\footnotetext{
235 Beagle Channel Decision, supra note 187 at para. 94.

${ }^{236}$ Ibid at para. 96.

${ }^{237}$ F.V., supra note 196 at 738.

${ }^{238}$ Beagle Channel Decision, supra note 187 at para. 99; Shaw, "Beagle Channel", supra note 186 at $427-428$; Himmelreich, supra note 187 at 980.

${ }^{239}$ Beagle Channel Decision, supra note 187 at para. 112.

${ }^{240}$ Ibid at paras. 113, 117, 129; F.V., supra note 196 at 739; Shaw, "Beagle Channel", supra note 186 at $432-433$.

${ }^{241}$ Shaw, "Beagle Channel”, Ibid at 432.

242 Beagle Channel Decision, supra note 187 at para. 136; Shaw, "Beagle Channel", Ibid at 433-434.

${ }^{243}$ Beagle Channel Decision, Ibid at paras. 122, 131.

${ }^{244}$ Ibid at para. 126; Kratochwil, Rohrlich \& Mahajan, supra note 186 at 75.

${ }^{245}$ Kratochwil, Rohrlich \& Mahajan, Ibid at 75.

246 Beagle Channel Decision, supra note 187 at para. 165.

${ }^{247}$ Ibid at paras. 166, 172.
} 
were relevant to the interpretation of the parties' intentions ${ }^{248}$ and "tended to confirm the correctness of the Chilean interpretation of the islands clause of the Treaty". ${ }^{249}$

Judge Gros drafted a separate declaration that was annexed to the arbitral award and emphasized the tribunal's textual and contextual approach to the interpretation of the Treaty. ${ }^{250}$ While endorsing the conclusion of the tribunal, he expressed a different approach to the use to be made of cartography and the conduct of the Parties subsequent to the signing of the Treaty: ${ }^{251}$

...I would point out...that it was not necessary from the legal point of view once the meaning of Article III had been decided on the basis of the text and of all the historical circumstances... ${ }^{252}$

He therefore could not

...follow the Court in its views concerning the conduct of the Parties after the Treaty, which is equally lacking in relevance, if account is taken of the Treaty relations and general principles of law binding on the Parties in the period under consideration. ${ }^{253}$

\subsection{The outcome of the arbitration}

The arbitral award, rendered in February 1977, established a boundary line roughly in the middle of the Channel and the PNL group was awarded to Chile. ${ }^{254}$ The award has been considered to “constitute a highly polished legal document...clearly founded upon international legal principles and its discussion of extra-legal factors [wa]s minimal". ${ }^{255}$ It has also been considered as exceptional, however, in that it completely endorsed one party's claims rather than reaching a compromise between the parties as in most boundary cases, and this result has been attributed to the composition of the tribunal. ${ }^{256}$

In May 1977, after the British Crown approved the award, ${ }^{257}$ Argentina issued a formal note rejecting it as being null and void under international law on the grounds that: (1) the tribunal

\footnotetext{
248 Shaw, "Beagle Channel”, supra note 186 at 437-439.

${ }^{249}$ Beagle Channel Decision, supra note 187 at para. 165.

${ }^{250}$ Shaw, "Beagle Channel", supra note 186 at 441.

${ }^{251}$ Argentina $v$ Chile (1977), Declaration of Judge Gros, 17:3 ILM 634, at para. 3 [Beagle Channel Declaration]; F.V., supra note 196 at 739.

${ }^{252}$ Beagle Channel Declaration, Ibid at para. 3; F.V., Ibid at 739-740; Shaw, "Beagle Channel", supra note 186 at 441.

${ }^{253}$ Beagle Channel Declaration, supra note 251 at para.4; F.V., supra note 196 at 740.

${ }^{254}$ Kratochwil, Rohrlich \& Mahajan, supra note 186 at 73; Laudy, supra note 190 at 299.

255 Shaw, "Beagle Channel", supra note 186 at 420.

256 Ibid at 441-442.

${ }^{257}$ Declaration of Her Majesty Queen Elizabeth II, Pursuant to the Agreement For Arbitration (Compromiso)
} 
distorted Argentina's arguments; (2) the tribunal overreached its competence by opining on disputed questions that were not submitted to arbitration in the compromis; (3) the award contained contradictions in the tribunal's reasoning; (4) the award contained interpretation defects; (5) the award contained geographical and historical errors; and (6) there was an imbalance in the evaluation of the arguments and evidence submitted by the parties. ${ }^{258}$

In 1978, Argentina and Chile signed the Act of Puerto Montt, providing for direct negotiations to resolve their dispute. These negotiations failed, however, and military mobilization ensued. In 1979, the parties agreed to Papal mediation, ${ }^{259}$ which in 1980 produced a decision that was partially rendered ex aequo et bono. The decision also awarded the PNL group to Chile, but limited potential Chilean claims to sovereignty in the Atlantic by restricting its maritime right to the Pacific waters on the basis of the Oceanic principle, and declaring the Channel itself to be binational. ${ }^{260}$ The Papal decision therefore "grasped the symbolic importance and face saving potential of the Oceanic principle", which was neglected by the arbitral tribunal, and Chile's acceptance of this principle "belie[d] the [tribunal]'s conclusion that no such principle exist[ed]". ${ }^{261}$ The two countries accepted the Papal decision and in 1984 signed a Treaty of Peace and Friendship that finally resolved the dispute. ${ }^{262}$

\subsection{Analysis}

The failure of the Beagle Channel arbitration to resolve the dispute between Chile and Argentina arguably emanated, at least in part, from the parties' and arbitral tribunal's one-dimensional focus on the "legal dimension" of the arbitral process, despite the complex nature of the dispute. The parties arguably approached the arbitration as an essentially judicial process, focusing on legal arguments grounded in legal principles and strict treaty interpretation while neglecting, both in their claims and in their perception of the arbitral tribunal's role, the significant non-legal aspects of their dispute. Similarly, the arbitrators arguably perceived themselves narrowly as

Determined by the Government of the United Kingdom of Great Britain and Northern Ireland and Signed on Behalf of That Government and the Governments of the Argentine Republic and the Republic of Chile on 22 July 1971 for the Arbitration of a Controversy Between the Argentine Republic and the Republic of Chile Concerning the Region of the Beagle Channel, 1978, 17:3 ILM 632.

${ }^{258}$ Himmelreich, supra note 187 at 980.

${ }^{259}$ Bercovitch \& Fretter, supra note 6 at 127.

${ }^{260}$ Kratochwil, Rohrlich \& Mahajan, supra note 186 at 73; Bercovitch \& Fretter, supra note 6 at 127; The Carter Center, supra note 17 at 23-24; Himmelreich, supra note 187 at 997.

${ }^{261}$ Himmelreich, Ibid at 997.

${ }^{262}$ Kratochwil, Rohrlich \& Mahajan, supra note 186 at 73; Bercovitch \& Fretter, supra note 6 at 127; The Carter Center, supra note 17 at 23-24. 
"judges" bound by the strict legal interpretation of a treaty, instead of employing a more flexible interpretation of the law in combination with an extra-legal "diplomatic" function to adequately address the non-legal issues in dispute.

\subsubsection{The parties}

Several aspects of the parties' one-dimensional approach to the arbitral process in this case may have contributed to its ultimate failure. First, arguably perceiving the arbitral process as akin to litigation, the parties failed to utilize one of the hallmark features and greatest advantages of arbitration - their ability to select their decision maker(s). The arbitrators in this case were all chosen by the British government, and none of them were from the parties' region, let alone nationals of the parties. This effectively deprived the parties their right to appoint arbitrators of their choosing who are familiar with the region, sympathetic to the parties' claims, and cognizant of the broader implications of their decision. The result in this case was an arbitral tribunal comprised solely of ICJ judges, which viewed itself as a court rather than an arbitral tribunal, perceived its role in strictly legal terms, and was arguably less familiar and engaged with the parties' underlying interests. Moreover, in light of the fact that Argentina had previously rejected an ICJ award granting the PNL group to Chile, its rejection of the same outcome reached by a so-called arbitral tribunal comprised solely of ICJ judges was to be expected.

Although it is an accepted practice in international arbitration to designate a third party to appoint some or all of the members of an arbitral tribunal, such third parties are generally neutral individuals or institutions that are detached from the disputed parties. In this case, however, the designated third party, the British government, shared a turbulent history with Argentina, including a long-standing dispute over the Falkland Islands. Argentina's historic distrust of the United Kingdom and its potential fear of bias, therefore, likely influenced its ultimate rejection of the unfavourable outcome in the Beagle Channel arbitration. ${ }^{263}$ If the British government did not have such a major role in setting up the arbitration, effectively subsuming the role naturally reserved for the parties themselves, the outcome of the arbitration, as well as its reception by Argentina, might have been different.

Indeed, in the immediate aftermath of Argentina's rejection of the arbitral award commentators already concluded that one of its likely results would be "a return...to a more flexible

${ }^{263}$ Himmelreich, supra note 187 at 988-989. 
composition of the tribunal...since in this way the parties could ensure that all its [sic] relevant interests might be considered, including those interests that straddled that ambiguous boundary between 'hard' law and 'soft' law". ${ }^{264}$ The 1984 Treaty of Peace and Friendship, for instance, provided that in the event that arbitration was commenced, it was to be conducted by a panel of five members, one appointed by each party who may be their nationals, and the remaining three were to be non-nationals to be selected either by agreement of the parties or by the Swiss government. $^{265}$

Furthermore, the parties defined the disputed issue in the compromis narrowly, as a technical or factual question, to be resolved by the arbitral tribunal "in accordance with the principles of international law". This narrow one-dimensional framing of the issues and limited authority granted to the tribunal likely contributed to its strict legal approach and the unsatisfactory outcome. In a complex dispute such as the present one, which extends beyond the limited and relatively straightforward boundary question and involves important strategic, economic, and political underlying interests, it is doubtful that the submission of a single narrow legal question to arbitration could result in a comprehensive decision that pays sufficient regard to "interests that are not ordinarily protected as rights". ${ }^{266}$ Rather, in order to obtain a satisfactory resolution in such complex disputes, parties should arguably frame the issues to be determined by the arbitral tribunal broadly to include both their legal and non-legal aspects, and allow for some flexibility in the governing law, so that the tribunal is able to adapt the applicable rules to the circumstances of the case. ${ }^{267}$ While states may be reluctant to entrust a third party with deciding political or vital issues ${ }^{268}$ "outside the law", ${ }^{269}$ the present case arguably suggests that not doing so may thwart the resolution of the overall dispute and result in an inadequate award.

In summary, the parties arguably focused on the "legal dimension" of the arbitral process to the exclusion of its "diplomatic dimension". They submitted a narrow factual-legal issue to be determined in accordance with international law by a panel of ICJ judges, thereby arguably failing to appreciate the broader scope of their dispute, recognize the unique two-dimensional

\footnotetext{
${ }^{264}$ Shaw, "Beagle Channel", supra note 186 at 445.

${ }^{265}$ Treaty of Peace and Friendship between Chile and Argentina (with annexes and maps), 29 November 1984, Articles 24-25, online: <http://www.un.org/Depts/los/LEGISLATIONANDTREATIES/PDFFILES/TREATIES/ CHL-ARG1984PF.PDF>.

${ }^{266}$ Trakman, supra note 15 at 642.

${ }^{267}$ For a contrary view see, e.g., Copeland, supra note 5 at 3084; Rabow, supra note 5.

${ }^{268}$ Rabow, Ibid at $122,135-136$.

${ }^{269}$ Trakman, supra note 15 at 622.
} 
nature of arbitration, and distinguish it from judicial settlement. This, in turn, led the parties to base their claims on legal rules and principles and focus solely on the territorial/maritime aspect of their dispute, largely ignoring its much deeper, more complex, aspects. These aspects were therefore left unresolved and ultimately prevented the settlement of the conflict. ${ }^{270}$

\subsubsection{The arbitral tribunal}

In addition to the parties' own misconceptions of the arbitral process in this case, the arbitral tribunal's one-dimensional reasoning and decision-making process arguably also contributed to its ultimate failure. Most notably, the arbitrators failed to act as "diplomats" and did not pay sufficient attention to "political realities" in deciding a dispute that was "primarily a manifestation or symbol of a more generalized conflict between the parties", and in which acceptance of an adverse decision was "not likely to be dissociated from the underlying tension". ${ }^{271}$ The nature of this particular dispute, therefore, arguably required the tribunal to take into account "political, moral, or other extra-legal considerations", and its failure to do so likely contributed, at least in part, to the rejection of the award by Argentina. ${ }^{272}$

This failure to take into account equity or non-legal considerations significantly limited the tribunal's ability to reach a flexible decision that balanced the parties' respective interests. The subsequent Papal mediation, in contrast, was no longer based on strict adherence to legal principles and therefore succeeded where the arbitral tribunal had failed. ${ }^{273}$ Although the parties did not authorize the arbitral tribunal to decide ex aequo et bono, it arguably retained the authority to apply equity, at least part of international law, ${ }^{274}$ in order to take into account "considerations of fairness, reasonableness, and policy often necessary for the sensible application of more settled rules of law". ${ }^{275}$ Such an approach would likely have prevented the tribunal from unequivocally accepting the claims of one party while entirely rejecting those of

\footnotetext{
${ }^{270}$ Kratochwil, Rohrlich \& Mahajan, supra note 186 at 76; Laudy, supra note 190 at 298.

${ }^{271}$ Himmelreich, supra note 187 at 992.

272 Ibid.

${ }^{273}$ Kratochwil, Rohrlich \& Mahajan, supra note 186 at 76.

${ }^{274}$ Holtzmann, "Reflections", supra note 144 at 274.

${ }^{275}$ Ibid at 273. See also Lachs, "Equity in Arbitration", supra note 15 at 325; Munkman, supra note 6 at 14 ; D.W. Greig, "The Beagle Channel Arbitration" (1976-1977) 7 Aust YBIL 332 at 384 [Greig]. In the 1968 Rann of Kutch arbitration between India and Pakistan, for instance, the arbitral tribunal based its decision on equity and "the paramount consideration of promoting peace and stability" even though it was not authorized by the parties to decide ex aequo et bono. Similarly, in the Guinea-Guinea Bissau maritime delimitation arbitration, the arbitral tribunal was to "decide according to the relevant rules of international law" and found that it was to achieve an "equitable solution" by the rule of law it selected to apply. Both decisions were accepted by the parties and settled their respective disputes, Pinto, "Prospects", supra note 4 at 83.
} 
the other. Instead, the tribunal's one-dimensional and restrictive legal approach arguably weakened the "logic and moral force" of its decision, ${ }^{276}$ and may have affected Argentina's motivation to implement it. $^{277}$

The tribunal also did not utilize the two-dimensional advantages of the arbitral process in order to reach a compromise, rather than a zero-sum outcome. For instance, regarding the interpretation of Article III of the Treaty, since the tribunal concluded that there was nothing pointing definitively to the view of one side or the other, ${ }^{278}$ and in light of the ambiguity of this Article ${ }^{279}$ it arguably ought to have furnished a decision that would account for the positions of both parties, rather than adopting one to the exclusion of the other. ${ }^{280}$ The tribunal's onedimensional legal approach and "narrow view of its role", ${ }^{281}$ however, prevented it from doing so. $^{282}$

This one-dimensional legal approach of the arbitral tribunal also extended to its use of "confirmatory" materials to supplement its strict treaty interpretation. While the tribunal reviewed such "confirmatory" materials in great length and detail, it declared that it was only using these to reinforce conclusions already made on the basis of treaty interpretation. ${ }^{283}$ The tribunal also recognized that "mixed factors of coastal configuration, equidistance, and also of convenience, navigability, and the desirability of enabling each Party as far as possible to navigate in its own waters" were relevant to determining the boundary-line, but it nonetheless maintained that there was "little deviation from the strict median line". ${ }^{284}$ This ambiguity and

\footnotetext{
${ }^{276}$ Himmelreich, supra note 187 at 982.

${ }^{277}$ For instance, while the tribunal's refusal to apply the Oceanic principle may have been "logically defensible", its complete rejection and discrediting of this principle compromised both the logic of its decision and its legitimacy. While the tribunal was not explicitly authorized to decide ex aequo et bono or based on equity, this "did not prevent a broad interpretation of the Treaty to include some version of the Oceanic principle" advanced by Argentina, Himmelreich, supra note 193 at 985-986, 997. Similarly, since the effects of sovereignty over the PNL group on maritime issues was clearly of great importance to Argentina, by "neglect[ing] the important contextual factor of the oceanic divide" the tribunal arguably failed to provide a logically and morally forceful award and led Argentina to question its judgment, Greig, supra note 275 at 382; Kratochwil, Rohrlich \& Mahajan, supra note 186 at 74.

${ }^{278}$ Greig, Ibid at 352.

${ }^{279}$ Ibid at 380-381.

${ }^{280}$ Instead, the tribunal merely noted that "the Chilean version, although not itself entirely free from difficulty, is the more normal and natural on the basis of the actual language of the text", Beagle Channel Decision, supra note 187 at para. 64. This, in turn, led Argentina to assert that the tribunal did not clearly favour Chile's interpretation, but rather "merely prefer[ed] it" over Argentina's "after having weighed up the sum total of their respective weaknesses", Himmelreich, supra note 187 at $989-990$.

${ }^{281}$ Greig, supra note 275 at 381.

${ }^{282}$ Himmelreich, supra note 187 at $989-990$.

${ }^{283}$ Shaw, "Beagle Channel", supra note 186 at 429.

${ }^{284}$ Beagle Channel Decision, supra note 187 at para. 110; Shaw, "Beagle Channel", supra note 186 at 431.
} 
formalistic reasoning likely further eroded the legitimacy and credibility of the arbitral tribunal's decision in the eyes of the parties.

Therefore, the "five Members of the Court sat ostensibly as arbitrators but in reality as judges on another bench". ${ }^{285}$ They not only restricted their role to that of "judges", ${ }^{286}$ but also carried out this role in a narrow, rigid, and legalistic manner that is arguably inappropriate in interstate arbitration. This is evident, for instance, from the length of the proceedings. The tribunal spent six years in deliberations before rendering the award, an unusually long period of time for an arbitration and arguably more characteristic of international court proceedings. ${ }^{287}$ The tribunal's self-perception is also evident from the fact that while it felt compelled to consider and analyze evidence external to the text of the Treaty, it refused to allow such evidence to influence its "positivistic" 288 interpretation of the text, on which it ultimately based its decision. A more flexible and contextual approach to treaty interpretation and the arbitrators' role as "judges", coupled with a broader, two-dimensional understanding of the arbitral process, was arguably called for in this case. Such an understanding was in fact exhibited by one of the members of the tribunal in an earlier arbitration between the parties, in which the "need to adjust as equitably as possible the conflicting claims of the two States" 289 was considered.

Had at least some of the members of the arbitral tribunal in this case been unaffiliated with the ICJ, the tribunal as a whole might have been more willing to apply such a two-dimensional, flexible, and conciliatory approach in its reasoning, which in turn may have influenced its ultimate decision and strengthened its legitimacy in the eyes of the parties. Having a dual role as both ad hoc arbitrators and ICJ judges arguably confounded the role and duties of the arbitrators in this case. Instead of acting as "judges-diplomats" responsible only to the parties before them and deciding the individual dispute on the basis of law, equity, and all non-legal relevant considerations, the arbitrators in this case acted as judges responsible to third parties or the international community for making and applying international law, and exercised rigid and legalistic decision making. ${ }^{290}$

\footnotetext{
${ }^{285}$ Lachs, "Arbitration and International Adjudication", supra note 17 at 48 .

${ }^{286}$ McWhinney, supra note 7 at 283.

${ }^{287}$ Himmelreich, supra note 187 at 996-997; Jeong, supra note 6 at 178.

${ }^{288}$ McWhinney, supra note 7 at 283.

${ }^{289}$ The 1902 Andean boundary dispute, Greig, supra note 275 at 381.

${ }^{290}$ Munkman, supra note 6 at 113-114.
} 
In summary, the one-dimensional approach adopted by the arbitral tribunal to the interpretation of the Treaty, while legally sound and seemingly justified in light of the narrow jurisdiction granted to it by the parties in the compromis, was overly legalistic and formalistic and also neglected to take into account the "diplomatic" dimension of the arbitral process, the broader context of the dispute, and the parties' underlying interests.. By so doing, the tribunal wasted an opportunity to formulate a compromise within the limits of the parties' claims and delegitimized itself and the arbitral award in the eyes of the losing party, Argentina, thereby contributing to the failure of the arbitration to resolve the dispute between the parties. ${ }^{291}$

\subsection{Conclusion}

There were several factors, both internal and external to the arbitral process, that arguably contributed to the ultimate failure of the Beagle Channel arbitration. Internally, both the parties and the arbitral tribunal failed to recognize the two-dimensional nature of interstate arbitration and to utilize it properly. The parties did not exercise their right to select their arbitrators and consented to arbitrators who were ICJ judges, and they unduly restricted the tribunal's jurisdiction to decide only narrow legal or factual issues in accordance with international law. Had the parties appointed neutral arbitrators, preferably including their own nationals or nonnationals who had a better understanding of the underlying conflict and its implications for the parties, and had they provided the tribunal with sufficiently broad jurisdiction to take the parties' non-legal interests into account, the resulting award would arguably be both more legitimate and more effective in resolving the parties' dispute. Similarly, the arbitrators restricted themselves to a rigid role of judges, applying a narrow and legalistic approach to the interpretation of the Treaty that excluded any equitable considerations and crucial extra-legal factors, disregarded the "symbolism of international politics", 292 and failed to devise a conciliatory settlement when one was both called for and possible, thereby compromising the legitimacy of the award and the likelihood of its implementation.

Externally, there were several factors that converged in 1983 and arguably made the conflict more amenable to resolution than before. First, changes in the law of the sea and a need for greater regional economic cooperation made the resolution of the dispute more pressing. Second, the increase in aggressive military confrontations between the parties made it clear that absent a

\footnotetext{
${ }^{291}$ Ibid at 27.

${ }^{292}$ Himmelreich, supra note 187 at 998.
} 
peaceful resolution to the dispute war would be inevitable. Third, and most significantly, major changes in Argentine domestic politics, including the rise of a democratic government, constituted "the primary impetus for the settlement ultimately achieved", as they facilitated the concessions made by Argentina in the 1984 Treaty of Peace and Friendship. ${ }^{293}$

While it is possible that the change in government in Argentina was a necessary condition for the successful arbitration of the dispute, ${ }^{294}$ without which no dispute settlement method could have succeed, it arguably would not have been a sufficient condition so long as arbitration continued to be used in the same deficient manner. At the same time, the fact that Papal mediation ultimately brought the dispute to a peaceful conclusion suggests that the involvement of a third party acceptable to the parties was required once the political conditions allowed for a settlement, which requirement could have arguably been satisfied by arbitration if it were properly applied. In any event, the ultimate failure of the arbitration in this case, rather than attesting to the inherent unsuitability of arbitration to resolve complex interstate territorial disputes, arguably emanated from the one-dimensional perception of the process and its inadequate use by the parties, and the self-restrictive and legalistic approach of the arbitral tribunal, coupled with the unsuitable external political conditions.

\section{The Taba Arbitration, 1988}

\subsection{Background}

This arbitration concerned the dispute between Israel and Egypt over the Taba area, a strip of land in the Sinai desert on the shore of the Gulf of Aqaba. ${ }^{295}$ Historically, Turkish forces occupied this area, but they were forced to withdraw under British pressure in 1906. After negotiations between Anglo-Egyptian and Turkish representatives, a territorial agreement was reached in 1906 that fixed the border between Egypt and the Ottoman Empire as running through Taba and provided for boundary pillars to be erected at intervisible points along this line. ${ }^{296}$ In 1915, however, the British military produced a map that showed the border as running along a

\footnotetext{
${ }^{293}$ Laudy, supra note 190 at 305-306, 315.

${ }^{294}$ Greenberg, Barton \& McGuinness, supra note 35 at 316.

295 Copeland, supra note 5 at 3081.

${ }^{296} \mathrm{Ibid}$. "Intervisible points means points each of which can be seen from the point before and the point after, and from each of which one can see the point before and the point after", E. Lauterpacht, "The Taba Case: Some Recollections and Reflections" (1989) 23 Isr L Rev 443 at 445 [Lauterpacht].
} 
line approximately three-quarters of a mile to the north-east of the 1906 line, and this map formed the basis of many subsequent British and Egyptian maps.

When Britain was granted the Mandate for the administration of Palestine in 1922 it repeatedly declared that the boundary between Egypt and Palestine was the one defined in the 1906 agreement and not in the 1915 map. Nonetheless, uncertainty persisted throughout the Mandate period and the first twenty years of Israel's existence regarding the precise location of the boundary. ${ }^{297}$ In the 1967 Six-Day War, Israel gained control of the Sinai Peninsula, including the Taba area. Fighting between Israel and Egypt continued until the 1979 Camp David Accords, when the Treaty of Peace ("Treaty") was signed and Israel agreed to return Sinai to Egypt in exchange for peace. ${ }^{298}$

The Treaty defined the boundary between Israel and Egypt as "the recognized international boundary between Egypt and the former mandated territory of Palestine", ${ }^{299}$ however there was disagreement concerning its location in the Taba area. A Joint Commission of military personnel established under the Treaty agreed on the location of 75 boundary pillars along the border, while 14 pillars in and around the Taba area remained disputed. Since the Treaty required conciliation or arbitration of disputes not resolved by negotiations, the parties entered into an agreement in 1982 to submit the question of the location of the remaining pillars "to an agreed procedure which will achieve a final and complete resolution". ${ }^{300}$ Israel wanted the dispute to be resolved by conciliation, so that economic and geographical considerations would be taken into account, while Egypt preferred arbitration since it considered that the border question required a more formal procedure. ${ }^{301}$ In 1986, the parties signed an agreement referring the dispute to arbitration. $^{302}$

\footnotetext{
${ }^{297}$ Copeland, supra note 5 at 3081-3082; Lauterpacht, Ibid at 447.

${ }^{298}$ Bercovitch \& Fretter, supra note 6 at 282; A. Kemp, \& U. Ben-Eliezer, "Dramatizing Sovereignty: the Construction of Territorial Dispute in the Israeli-Egyptian Border at Taba" (2000) 19(3) Political Geography 315 at 320 [Kemp \& Ben-Eliezer].

${ }^{299}$ Israel v Egypt (1988), 20 Rep Int'l Arb Awards 3, at para. 99 [Taba Arbitral Award]; Copeland, supra note 5 at 3082; Lauterpacht, supra note 296 at 444.

${ }^{300}$ Initial Procedure for Resolving Boundary Questions (April 25, 1982) 26 I.L.M. 1987 at 14.

${ }^{301}$ Ruth Lapidoth, "Some Reflections on the Taba Award" (1992) 35 German Yearbook of International Law 224 at 234 [Lapidoth, "Reflections"]; Ruth Lapidoth, "The Taba Controversy" (1986) 37 The Jerusalem Quarterly 29 at 35 [Lapidoth, "Controversy"].

302 Taba Arbitral Award, supra note 299 at paras, 2-3, 104; Bowett, supra note 6 at 429; Copeland, supra note 5 at 3082; Gunnar Lagergren, “The Taba Tribunal 1986-1989” (1989) 1 Afr J Int'l \& Comp L 525 at 525 [Lagergren].
} 
Aside from the issue of territorial sovereignty, the dispute over Taba also concerned several hundred meters of shoreline, corresponding territorial water rights, and a multi-million dollar resort hotel complex and tourist village ("Sonesta hotel complex"), which made this area economically valuable. ${ }^{303}$ That said, there is no doubt that, when compared with other territorial concessions made by Israel under the Treaty, the Taba area was relatively insignificant. The protracted dispute over the area is therefore a testament to the complexity of territorial disputes in the Middle East and to the "intractable nature" of the Israeli-Palestinian conflict, ${ }^{304}$ in which territory may have greater symbolic significance than actual objective value.

\subsection{The arbitration agreement and procedure}

On 11 September 1986, Egypt and Israel signed an arbitration agreement (“Arbitration Agreement"), which provided that the "boundary dispute concerning the Taba beachfront" shall be submitted to an arbitral tribunal consisting of five members. The tribunal members included three non-nationals, Gunnar Lagergren (Sweden) as President, Pierre Bellet (France), and Dietrich Schindler (Switzerland), and two nationals of the parties, Hamed Sultan (Egypt) and Ruth Lapidoth (Israel).

Article II of the Arbitration Agreement provided that the tribunal was to decide "the location of the boundary pillars of the recognized international boundary between Egypt and the former mandated territory of Palestine, in accordance with the Peace Treaty, the April 25, 1982 Agreement, and the Annex". The Annex to the Arbitration Agreement set out the 14 disputed boundary pillars to be determined by the arbitral tribunal and the parties' respective positions regarding their location.

The Arbitration Agreement contained two unusual features. First, pursuant to an Israeli formula of "conciliatory arbitration", 305 the Agreement provided for a conciliation process within the arbitration. For this purpose, it created a "three-member chamber" composed of the two partyappointed arbitrators and one non-national member of the tribunal other than the President. The task of this chamber was to "explore the possibilities of a settlement of the dispute" and to make

\footnotetext{
${ }^{303}$ Haihua Ding \& Eric S. Koenig, "Treaties-Treaty of Peace Between Egypt and Israel -Demarcation of Internationally Recognized Boundaries - Arbitration of Disputes - Taba" (1989) 83 Am J Int'l L 590 at 593 [Ding \& Koenig]; Copeland, supra note 5 at 3082, 3084.

${ }^{304}$ Kemp \& Ben-Eliezer, supra note 298 at 316.

305 Ibid at 325.
} 
recommendations to the parties regarding such possibilities before the completion of the written pleadings. Should the parties jointly accept a settlement recommendation made by the chamber, the arbitration process would terminate. ${ }^{306}$

Second, Article 5 of the Annex to the Arbitration Agreement provided that "the Tribunal is not authorized to establish a location of a boundary pillar other than a location advanced by Israel or by Egypt", and that "the Tribunal also is not authorized to address the location of boundary pillars other than those specified in paragraph 1", which included the 14 disputed pillars. ${ }^{307}$

\subsection{The parties' claims}

Both parties arguably focused on the "legal dimension" of the arbitration, basing their arguments regarding the appropriate location of the boundary pillars ${ }^{308}$ largely on treaty interpretation and principles of international law. For instance, both parties relied extensively on the legal principle of "critical date". ${ }^{309}$ Israel submitted that the critical date was 1906, when Egypt and Turkey agreed to establish the boundary line and a Joint Egyptian-Turkish Commission demarcated that line by erecting boundary markers. According to Israel, any pillars that were at variance with the 1906 agreement were of no legal significance, since no pillars were ever recognized as boundary pillars during the period of the Mandate, the only "recognized" boundary during that period being the line defined by the 1906 agreement. ${ }^{310}$ Moreover, this boundary line was recognized by Great Britain, as the mandatory power. Israel relied exclusively on the 1906 agreement since it

\footnotetext{
${ }^{306}$ Agreement to Arbitrate the Boundary Dispute Concerning the Taba Beachfront (Israel and Egypt), 11 September 1986, 26 ILM 1, Annex, Article IX [Taba compromis].

${ }^{307}$ Ibid, Annex, Article 5.

${ }^{308}$ The 14 disputed boundary pillars were divided into three groups. The first group was the "Nine Northern Pillars", consisting of nine pillars set apart by very small distances. These were situated in an uninhabited desert region and involved no essential interests of the Parties. The second group comprised of four pillars in the "Ras-el-Naqb area", three already in existence and one new pillar. According to Egypt, the three existing pillars were in its territory, while Israel claimed that the location of the pillars as argued by Egypt was inconsistent with the 1906 agreement and therefore should be rejected. The third group consisted of only a single pillar in "Ras Taba", but presented the most disputed issue between the parties. In the Annex to the Arbitration Agreement, the parties described this pillar as the "final boundary pillar...at the point of Ras Taba on the Western shore of the Gulf of Aqaba". Taba Arbitral Award, supra note 299 at paras. 152-155, 182; Copeland, supra note 5 at 3083; Bowett, supra note 6 at 432-434; Taba compromis, supra note 306, Annex, Article 2; Lapidoth, "Reflections", supra note 301 at 236.

${ }^{309}$ According to this principle, a tribunal must determine the date on which the dispute over territorial sovereignty or boundary location can be said to have "crystallised". The Tribunal then decides who was sovereign, or where the boundary lay, on that critical date, Bowett, supra note 6 at 430-431.

310 Taba Arbitral Award, supra note 299 at paras. 142-143; Prosper Weil, "Some Observations on the Arbitral Award in the Taba Case" (1989) 23 Isr L Rev 1 at 3 [Weil].
} 
described the boundary pillars as "intervisible", and Israel's suggested locations met this "intervisibility test". 311

Egypt, on the other hand, submitted that the critical date could be anytime during the Mandate period between 1922 and 1948, and therefore that the "recognized international boundary" in the Treaty was the line linking the boundary pillars existing on the ground during this period. ${ }^{312}$ Egypt referred in this regard to the need "to bring into operation the general legal principles of the stability and finality of boundaries, the succession of States to territory, estoppel, acquiescence, and de facto agreement so as to preclude Israel's claims based on application of the terms of the 1906 Agreement".313

Moreover, with respect to the "Ras Taba" pillar, which constituted the most disputed issue between the parties and was particularly significant in light of Israel's construction of the Sonesta hotel complex at the same location, Israel again based its arguments on principles of international law and a narrow interpretation of the parties' Arbitration Agreement. It put forward two proposals for the location of this pillar, both resulting in the hotel complex being placed on the Israeli side of the boundary, on the basis of the intervisibility principle set out in the 1906 agreement. Israel also argued that the reference in the Annex to the Arbitration Agreement to this pillar as being the "final" boundary pillar meant that the tribunal could not adopt either one of the positions of the parties, since the "final" pillar was in fact another pillar named the "Parker pillar", which was destroyed by Israel in 1970, and the location of the latter was not argued as the location of the "Ras Taba" pillar by either party. Since according to the Arbitration Agreement the tribunal could not decide on any location not advocated by the parties, Israel argued that the result with respect to this pillar was one of non licet. ${ }^{314}$

Egypt, on the other hand, advocated for a different, northern, location for the pillar on the basis of alleged remnants of an original pillar at that location, ${ }^{315}$ disputed that any error had been made

\footnotetext{
311 Taba Arbitral Award, supra note 299 at paras. 144, 149-150; Bowett, supra note 6 at 432.

312 Taba Arbitral Award, Ibid at paras. 111-113; Bowett, Ibid at 431-432; Copeland, supra note 5 at 3082.

313 Taba Arbitral Award, Ibid at para. 113; Weil, supra note 310 at 3.

${ }^{314}$ Taba Arbitral Award, Ibid at para. 239; Bowett, supra note 6 at 435, 438-439. Israel attempted to distinguish this term from "non liquet", meaning that there is no international law applicable to the dispute and therefore it cannot be decided by the court or tribunal, which has largely been rejected in jurisprudence and scholarship, Yoram Dinstein, "psak haborerut beparashat taba" (1989) 14 Tel Aviv U L Rev 57 (in Hebrew) at 63 [Dinstein].

${ }^{315}$ Bowett, supra note 6 at 434-436. Israel disputed Egypt's position and argued that the remnants did not represent a true boundary pillar but rather markers used for surveying purposes, and that the maps showing them as a
} 
in the relevant maps, and argued that the remnants resembled a boundary pillar and that such a pillar was required in that location as a result of the location of the other existing pillars. ${ }^{316}$

\subsection{The arbitral tribunal's decision making process}

The three-member chamber set up to provide the parties with recommendations was comprised of the two national arbitrators and Mr. Bellet. It conducted consultations with the parties, however none of the ideas explored were acceptable to both parties. Since the chamber did not wish to make a recommendation that would not be approved by the parties, ${ }^{317}$ it "regretted not having been able to propose to the Parties any recommendation for a settlement of the dispute", 318 and the arbitration therefore proceeded.

At the arbitration stage, the tribunal arguably adopted a two-dimensional approach to the parties' dispute despite the parties' narrow legal attitude by interpreting broadly any relevant legal principles and taking into account extra-legal considerations. The tribunal accordingly rejected the parties' reliance on the principle of "critical date" and adopted a "critical period" instead as the basis for its decision, specifically the 1923-1948 Mandate period. The tribunal also rejected Israel's exclusive reliance on the 1906 agreement and found that this position did not accord with the description of the boundary in the Treaty and the Arbitration Agreement. ${ }^{319}$ The tribunal therefore rejected Israel's arguably legalistic approach and set out to determine the location of the disputed pillars on the basis of the boundary "as it was demarcated, consolidated, and commonly understood during the period of the Mandate". ${ }^{320}$ For this purpose, the tribunal examined "where the boundary pillars stood" and what was "the situation on the ground" during this period. ${ }^{321}$

boundary pillar, based on the 1915 British map, were incorrect. Therefore, according to Israel, the boundary had to be fixed in accordance with the 1906 agreement.

${ }^{316}$ Egypt further argued that Israel had acted in bad faith in purposefully concealing from it during their negotiations the existence of the "Parker pillar" it had destroyed, thereby tricking Egypt into describing its suggested location of the "Ras Taba" pillar as the "final" pillar in the Annex to the Arbitration Agreement, Bowett, supra note 6 at 437440.

${ }^{317}$ Lapidoth, "Reflections", supra note 301 at 239.

${ }^{318}$ Taba Arbitral Award, supra note 299 at para. 11; Lagergren, supra note 302 at 528.

${ }^{319}$ Taba Arbitral Award, Ibid at paras. 169-175; Bowett, supra note 6 at 431; Copeland, supra note 5 at 3082.

${ }^{320}$ Taba Arbitral Award, Ibid at para. 172.

${ }^{321}$ Ibid at para. 173. With regard to the location of the disputed "Nine Northern Pillars", the tribunal found the evidence presented by both sides unpersuasive and decided in favour of the proposed locations nearest to a straight line drawn from agreed pillar locations, which resulted in five of the pillars being awarded to Egypt and four to Israel. With respect to the pillars in the "Ras-el-Naqb area", the majority found that the three existing pillars had been in Egypt's territory since at least 1915 and that the available maps did not support the boundary line as claimed by Israel. The majority therefore rejected Israel's argument based on the 1906 agreement, finding that the three 
With regard to the disputed "Ras Taba" pillar, the majority of the arbitral tribunal found that the evidence as well as the parties' conduct over the years indicated that there was indeed an original pillar at the location argued by Egypt. Furthermore, the tribunal found that the location of this pillar, as well as that of the "Parker pillar", was not intervisible with the other existing boundary pillars. Therefore, to support its suggested intervisible pillar location, Israel had to prove both that the "Parker pillar" was wrongly located and that the 1906 agreement, rather than the actual demarcation on the ground, governed, which the majority found Israel had failed to do. ${ }^{322}$

With regard to the description of this pillar in the Annex to the Arbitration Agreement as being the final pillar on Ras Taba on the Western shore, the majority again chose a more "diplomatic" and less legalistic approach than that put forward by Israel, finding that although this description corresponded to the original description of the "Parker pillar" in the 1906 agreement, it was also compatible with the pillar location suggested by Egypt. ${ }^{323}$ The majority found that these words must be read in light of the requirement under the Arbitration Agreement that the parties indicate their positions regarding the location of the pillars "on the ground", 324 and noted that this was not possible with respect to the "Parker pillar" since Israel had destroyed it. Therefore, in the absence of the actual "Parker pillar", the location proposed by Egypt for the "Ras Taba" pillar in fact constituted the "final pillar" along its claimed boundary. ${ }^{325}$

Prof. Ruth Lapidoth, the arbitrator appointed by Israel, rendered a dissenting opinion in which she arguably adopted a more textual, legalistic approach, finding that the correct boundary was that set out in the 1906 agreement and recognized by Egypt and Great Britain, regardless of later

existing pillars located in Egypt's territory were not inconsistent with this agreement. The majority also discussed the speculative situation that would have arisen had there been such inconsistency between the existing pillar locations and the 1906 agreement, finding that a jointly agreed demarcation should prevail over the text of the agreement. Finally, the majority also awarded the fourth new pillar to Egypt, since its proposed location was closer to the straight line it had drawn between the existing pillars. Taba Arbitral Award, Ibid at paras. 187, 197-213; Bowett, supra note 6 at 432-434; Ding \& Koenig, supra note 303 at 594; Copeland, supra note 5 at 3083.

${ }^{322}$ Taba Arbitral Award, supra note 299 at paras. 214-245; Bowett, supra note 6 at 436.

${ }^{323}$ Taba Arbitral Award, Ibid at paras. 238-244; Lapidoth, "Reflections", supra note 301 at 232-233.

${ }_{324}^{324}$ Taba compromis, supra note 306, Annex, Article 2.

${ }^{325}$ The majority also noted that the principle of the stability of boundaries required that boundary markers accepted as such by the concerned states "should be respected and not open to challenge indefinitely on the basis of error" (Taba Arbitral Award, supra note 299 at paras. 235; Bowett, supra note 6 at 435-438). The tribunal rejected, however, Egypt's allegations of bad faith on the part of Israel with regard to the use of the words "final pillar". Finally, the tribunal found that, due to the strict limitations on its jurisdiction, it was not authorized to determine the boundary line from the "final pillar" to the shore and beyond. Taba Arbitral Award, supra note 299 at paras. 165, 242; Bowett, supra note 6 at 435, 439-440. 
developments on the ground. ${ }^{326}$ Therefore, Prof. Lapidoth found that the location of the "Ras Taba" pillar and the "Parker pillar" as argued by Egypt were contrary to the 1906 agreement in light of their lack of intervisibility, and therefore should be rejected. ${ }^{327}$

Moreover, according to Prof. Lapidoth, once the majority recognized that the "Parker pillar" was the "final" one during the "critical" Mandate period, and that it satisfied the conditions set out in the Annex to the Arbitration Agreement, the "Ras Taba" pillar could not also be regarded as the final pillar, since the two were mutually exclusive. ${ }^{328}$ Therefore, Prof. Lapidoth accepted one of the pillar locations proposed by Israel, which it found to conform with the 1906 agreement since it was intervisible. ${ }^{329}$

\subsection{The outcome of the arbitration}

In 1988, two years after the parties entered into the Arbitration Agreement, the arbitral tribunal rendered an award in which it unanimously decided that five of the "Nine Northern Pillars" were located on Egyptian territory and four on Israeli territory, and by majority that the "Ras-el-Naqb area" and "Ras Taba" pillars were located on Egyptian territory. ${ }^{330}$

After the arbitral award was rendered there was concern that Israel would refuse to withdraw from the Taba area on the ground, which was implied in the dissenting opinion, that a 170m long boundary line between the "final pillar" as decided by the tribunal and the shore was left undecided. ${ }^{331}$ Moreover, the Israeli government faced fierce opposition to the award from Israeli citizens who worked in Taba, ${ }^{332}$ and it seemed that the "Taba affair would come full circle to its starting point". ${ }^{333}$ At the same time, talks continued between Egypt and Israel in an effort to reach a compromise on a variety of issues that were not submitted to arbitration, including arrangements for entering the Taba area and management of assets located there, and a struggle

\footnotetext{
${ }^{326}$ Taba Arbitral Award, supra note 299, dissenting opinion of Prof. Lapidoth, at paras. 18-31, 41-42, 49.

${ }^{327} \mathrm{Ibid}$, at paras. 32-39. By the same token, with respect to the pillars in the "Ras-el-Naqb area", Prof. Lapidoth found that the description of the boundary in the 1906 agreement should prevail over the existence of pillars on the grounds and on maps, Ibid at paras. 166-184.

$328 \mathrm{Ibid}$, at paras. $54-76,150-165$.

${ }^{329} \mathrm{Ibid}$, at paras. 112-149. Prof. Lapidoth also found that the "stability" that must be protected was not that of the de facto boundary, as opined by the majority, but rather that of the de jure boundary as set out in the 1906 agreement, Ibid, at paras. 49, 89, 96; Dinstein, supra note 314 at 61-62, 64; Lapidoth, "Reflections", supra note 301 at 230-233.

${ }^{330}$ Lagergren, supra note 302 at 531.

${ }^{331}$ Taba Arbitral Award, supra note 299, dissenting opinion of Prof. Lapidoth, at para. 165; Kemp \& Ben-Eliezer, supra note 298 at 337.

${ }^{332}$ Copeland, supra note 5 at 3084.

${ }^{333}$ Kemp \& Ben-Eliezer, supra note 298 at 339.
} 
for effective control was waged in the form of "wars of signs" and "wars of flags" between Israeli and Egyptian liaison officers. ${ }^{334}$

Israel eventually withdrew from the Taba area after an agreement was signed between the parties in 1989, pursuant to which Egypt acquired the Sonesta hotel complex and it was agreed that the end of the boundary line would be on the shore at the location of the "Parker pillar". 335

\subsection{Analysis}

The Taba arbitration, while seemingly concerned with a narrow issue of the location of a few boundary pillars, in fact turned out to be quite complex and unusual. The parties' underlying interests in the Taba area were not clearly evident, and there seemed to be little economic or strategic value to this piece of land. However, the boundary question submitted to arbitration was in fact highly political and constituted merely one aspect of a much broader and more complex conflict that the parties eventually resolved through negotiations. While the arbitrators ultimately managed to resolve the disputed issue submitted to them by adopting a two-dimensional view of the arbitral process and of their own role as "judges" and "diplomats" rather than strictly the former, their success in doing so was arguably partial at best as a result of the extremely limited jurisdiction granted to them by the parties. The parties' one-dimensional narrow view of the arbitration as a "legal" process and their refusal to allow the arbitral tribunal to reach a settlement arguably compromised the tribunal's ability to effectively resolve even the narrow question submitted to it, and the complete failure of the arbitration was arguably prevented only by the broad approach adopted by the tribunal and the unique circumstances of the conflict between the parties.

\subsubsection{The parties}

The parties' narrow and overly-detailed framing of the issue to be determined by the arbitral tribunal in the Arbitration Agreement, as well as the limited authority granted to the tribunal to decide this issue, reflected their one-dimensional legal view of the arbitral process and arguably led to a partial and "winner-takes-all" outcome that was not readily implemented and left many disputed issues unsettled.

\footnotetext{
334 Ibid at 340.

${ }^{335}$ Ding \& Koenig, supra note 303 at 594-595; Copeland, supra note 5 at 3081, 3084; Kemp \& Ben-Eliezer, supra note 298 at 341- Lapidoth, "Reflections", supra note 301 at 233.
} 
The parties' overly-specific instructions and overly-detailed descriptions of the issue to be determined by the arbitral tribunal in the Arbitration Agreement arguably frustrated the tribunal's ability to render a comprehensive two-dimensional decision that accounted for the parties' positions and all relevant facts. The detailed description of the "Ras Taba" pillar, coupled with the restrictive authority granted to the tribunal to decide only between the parties' positions, arguably compromised the tribunal's ability to render a logically sound decision within the confines of the Arbitration Agreement since it was forced to choose between locations that did not entirely comply with the requirements of the Arbitration Agreement. Although the tribunal found that the original pillar was not at any of the locations advocated by the parties and clearly preferred a different location, it was required to choose one of the parties' positions over the other. $^{336}$

As a result of the narrow legal issue submitted to the arbitral tribunal's determination in the Arbitration Agreement, the arbitral award only partially resolved the parties' dispute, leaving unsettled such issues as the extension of the boundary from the "final" pillar to the sea, ${ }^{337}$ which were finally settled in a negotiated agreement in $1989 .{ }^{338}$ While the issue of the location of the boundary pillars may seem technical, the tribunal was in effect charged with the task of establishing facts on the ground through a careful consideration of the evidence rather than the application of legal principle. ${ }^{339}$ In light of the nature of this task, it is quite regrettable that the parties effectively tied the hands of the tribunal and prevented it from reaching an informed decision based on the available evidence and on the parties' respective interests.

Furthermore, by limiting the arbitral tribunal's decision making authority and preventing it from deciding in accordance with where it actually considered that the boundary should be ${ }^{340}$ the parties turned the arbitration into a zero-sum game. While this approach generally risks frustrating the arbitral process and rules out any prospect of a compromise solution, in the present case it may have been legitimate in light of the parties' desire to dispense with a relatively minor issue that was standing in the way of implementing a much broader and more complex peace agreement. $^{341}$

\footnotetext{
${ }^{336}$ Lapidoth, "Reflections", Ibid at 236.

${ }^{337}$ Lauterpacht, supra note 296 at 461; Weil, supra note 310 at 24.

${ }^{338}$ Lapidoth, "Reflections", supra note 301 at 248.

339 Bowett, supra note 6 at 430.

${ }^{340}$ Lapidoth, "Reflections", supra note 301 at 229.

${ }^{341}$ Copeland, supra note 5 at 3083-3084.
} 
In fact, "once the prospect of a meaningful agreement became real, both parties appreciated that the issue was strategically meaningless and that under no circumstances could it be permitted to disrupt the peace relationship that was, by then, seen as serving their common interests." 342 Therefore, Israel and Egypt were arguably not seeking to use arbitration to reach a compromise so much as an authoritative third party to choose between their respective positions, and they were prepared to accept whatever zero-sum result was decided so long as the issue was resolved. The parties' inclusion of a parallel but separate conciliation process in the Arbitration Agreement arguably also evidences their intention to either agree on a compromise suggested by the conciliators or accept the consequences of an "all or nothing" arbitral award. Secure in the knowledge that all other possibilities have been considered and rejected, the parties may have been more comfortable with accepting the binding zero-sum decision of the arbitral tribunal.

Despite the unique circumstances of this case, and even though Israel ultimately accepted the tribunal's ruling and withdrew from the Taba area, the parties should arguably have included a conciliatory aspect within the arbitral process itself, rather than externally to it, by utilizing its two-dimensional nature, broadening the authority of the tribunal and the questions submitted to it, and authorizing it to reach a compromise solution even if it diverged from their own positions. First, it is rare that "a State is aware before the litigation commences of the full range of the matters and arguments that may be available in support of its case or, indeed, of its opponent's case". ${ }^{343}$ It may therefore prove quite counterproductive for parties to define both the issues to be determined by the arbitral tribunal and how it should determine them in such a narrow manner in the arbitration agreement.

Second, a compromise solution in this case could have "soften the blow" for Israel, which was already returning vast territory to Egypt under the Treaty and arguably had a much weaker claim to the Taba area than its counterparty in any event. ${ }^{344}$ The arbitral award also resulted in considerable uncertainty in the months following the arbitration as to whether Israel would in fact honour the tribunal's decision, and tense exchanges between the parties seemed to indicate that the dispute was far from resolved. ${ }^{345} \mathrm{Had}$ the arbitrators been permitted to act fully as "diplomats" and devise a compromise, Israel may have been more willing to comply and much

\footnotetext{
${ }^{342}$ Reisman, "Reflections", supra note 23 at 41.

${ }^{343}$ Lauterpacht, supra note 296 at 466.

${ }^{344}$ Bowett, supra note 6 at 440.

${ }^{345}$ Kemp \& Ben-Eliezer, supra note 298 at 339-341.
} 
time and effort would have been saved in further negotiations. ${ }^{346}$ As it stood, the arbitration could just as easily have resulted in Israel's refusal to implement the award and a further deterioration of the conflict had it not been for the unique circumstances of the parties' broader conflict and peace process.

While the parties arguably failed to recognize the full potential of the two-dimensional nature of arbitration, they did utilize other advantages of the arbitral process. The parties were able to agree on neutral arbitrators and to appoint their own nationals to the tribunal, which presumably was of particular importance in light of the politically charged background of the dispute and the parties' prolonged conflict. ${ }^{347}$ They also succeeded in obtaining an authoritative and binding decision peacefully settling a disputed question that proved impossible to settle by agreement and that jeopardized their broader peace process.

In summary, while the parties ultimately resolved their dispute over the Taba strip by arbitration, this case is somewhat exceptional in light of its context and the particular purpose for which the parties used the arbitral process, and it therefore does not reflect best practices of state parties in interstate territorial arbitrations generally. On the other hand, the case does illustrate the advantages of arbitration where the parties are not prepared, due to domestic pressure or political constraints, to make voluntary concessions on a particular issue even if it is of relatively minor significance.

\subsubsection{The arbitral tribunal}

Although the tribunal's authority and discretion were severely restricted by the parties in the Arbitration Agreement, it managed to conduct the proceedings effectively and paid considerable regard to the political context and complexity of the dispute, the sensitive relationship between the parties, and the need for a diplomatic, rather than strictly legal, solution that is as practical and fair as possible in the circumstances. Any weaknesses in the arbitral award, therefore, should arguably be attributed to the parties' one-dimensional and narrow approach rather than the attitude and conduct of the arbitral tribunal.

\footnotetext{
${ }^{346}$ Israel in fact considered that there were "a variety of means by which each side could have obtained an acceptable degree of satisfaction if the Tribunal were not firmly tied to an absolute choice between the locations identified by the two sides". But the limitation on the tribunal's power was requested by Egypt and Israel consented as a result of pressure from the United States and in order not to derail the negotiations, Lapidoth, "Reflections", supra note 301 at 236; Lauterpacht, supra note 296 at 451-452.

${ }^{347}$ Copeland, supra note 5 at 3082.
} 
Conscious of the sensitive circumstances of the case and their role as "diplomats", the arbitrators avoided any "emotive" ${ }^{, 348}$ reasoning that might have clouded its appearance of impartiality, and maintained a diplomatic and unbiased position throughout the proceedings. ${ }^{349}$ The tribunal also took care to address in detail the arguments of both sides, even where these could have been dismissed outright. ${ }^{350}$ The tribunal's diplomatic yet legally "rigorous" approach was therefore both "prudent and compelling" and likely contributed to the ultimate acceptance and execution of the award. ${ }^{351}$

The arbitral tribunal also recognized its two-dimensional role and interpreted the Arbitration Agreement, and its authority under it, broadly where possible in order to resolve the parties' dispute effectively. ${ }^{352}$ Most significantly, the tribunal adopted a flexible approach to the interpretation of the location of the "Ras Taba" pillar as described by the parties in the Arbitration Agreement, which did not entirely conform with either one of their positions. Faced with this contradictory of terms in the Arbitration Agreement, the tribunal had several options: it could have found that it was unable to decide the question of the location of the "Ras Taba" pillar since this was a situation of non licet; it could have disregarded the requirement to choose between the parties' positions and determine that the correct location was that of the "Parker pillar"; or it could have disregarded the geographic description of the pillar and pick one of the

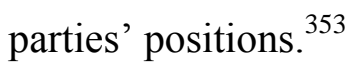

\footnotetext{
348 Bowett, supra note 6 at 339.

${ }^{349}$ For instance, the tribunal avoided Egypt's assertion that Israel had acted in bad faith in not disclosing to Egypt during negotiations the existence of the "Parker pillar" and allowing the latter to describe the proposed location of the "Ras Taba" pillar as the "final pillar" in the Arbitration Agreement. Similarly, the tribunal stayed clear of many other accusations brought by Egypt against Israel, including that Israel had destroyed boundary pillars, altered maps post-1982, falsified photographs, withheld evidence, and concealed its true case until the oral hearing, Ibid at 339441.

${ }^{350}$ For instance, while it accepted Egypt's position regarding the location of the boundary pillars in the "Ras-elNaqb area", the tribunal did not reject Israel's argument in this regard merely on the ground that these pillars had been accepted by Great Britain and Egypt during the Mandate period and therefore had to be respected, as it could have. Rather, it analyzed in detail Israel's argument based on the 1906 agreement and map evidence, and rejected it on its merits, Ibid at 433.

351 Ibid at 440-442.

${ }^{352}$ For instance, even though the Arbitration Agreement provided that the tribunal "is not authorized to address the location of boundary pillars other than those specified in paragraph 1", it nonetheless determined the location of the "Nine North Pillars" by reference to a straight line between the adjacent agreed pillars, thereby arguably "addressing other pillars". The tribunal also determined the location of the "Parker pillar", which was not included in the Arbitration Agreement. The tribunal, while noting that this question fell outside its jurisdiction, effectively decided the location of the "Parker pillar", which led it to accept Egypt's proposed location of the "Ras Taba" pillar over Israel's. Taba compromis, supra note 306, Annex, Article 5; Lapidoth, "Reflections", supra note 301 at 236 ; Taba Arbitral Award, supra note 299 at paras. 181, 231, 233, 245; Dinstein, supra note 314 at 62-64.

${ }^{353}$ Lapidoth, "Reflections", supra note 301 at 240; Weil, supra note 310 at 17.
} 
The majority of the arbitral tribunal did not declare the question of the "Ras Taba" pillar as non licet, even though this has been done in the past in delimitation arbitrations. ${ }^{354}$ The majority was aware of the factual context of the dispute, namely Israel's presence in the disputed area, and presumably wished to avoid perpetuating this situation, which was unfavourable to Egypt. It avoided this undesirable result by applying ingenious and legally flexible reasoning while largely remaining within the strict limits of the Arbitration Agreement. ${ }^{355}$ Rather than exceeding, or entirely failing to fulfill, its mandate on this point, the majority decided that the geographic description matched the "Parker pillar", but that the location claimed by Egypt matched it as well. While this decision was criticized in Prof. Lapidoth's dissenting opinion as contradictory to the requirement of a single "final" pillar and the terms of the 1906 agreement, the majority's approach should arguably be viewed as creative and flexible, albeit imperfect, and as providing the parties with a definitive decision despite contradictory instructions and very limited powers, thereby fulfilling its purpose of settling the dispute. ${ }^{356}$

The arbitral tribunal's approach to the application of international law and accepted legal principles is also noteworthy. While the Arbitration Agreement contained no direct reference to international law, but only to three agreements concluded by the parties, it is doubtful that this effectively excluded the application of international law, particularly since the Treaty explicitly referred to such application. ${ }^{357}$ Nonetheless, the arbitral tribunal largely relied on testimony and documentary evidence submitted by the parties in its decision making, rather than on established international law, ${ }^{358}$ and ultimately found that the location of the disputed pillars was to be determined on the basis of the effective situation on the ground during the critical period rather than the provisions of the delimitation treaty. ${ }^{359}$

Furthermore, the award in this case has been considered by some commentators as "running against the mainstream of international law" 360 since in disputes over delimitation, as in the present case, considerations of legal title under treaties tend to prevail over factual situations. ${ }^{361}$

\footnotetext{
${ }^{354}$ Taba Arbitral Award, supra note 299 at para. 244.

${ }^{355}$ Weil, supra note 310 at $19,21$.

${ }^{356}$ Lapidoth, "Reflections", supra note 301 at 241-242; Robert McCorquodale, "International Boundary Decisions Pillars of Salt?" (1989) 48 Cambridge LJ 352 at 354 [McCorquodale].

${ }^{357}$ Lapidoth, "Reflections", supra note 301 at 237.

${ }^{358}$ Copeland, supra note 5 at 3084.

${ }^{359}$ Lapidoth, "Reflections", supra note 301 at 243, 246-247.

${ }^{360}$ Weil, supra note 310 at 12.

${ }^{361}$ Ibid at 10-11.
} 
It may be that the absence of a specific reference to international law in the Arbitration Agreement was interpreted by the tribunal as permitting it to depart from established international legal principles in favour of what it may have perceived to be a better outcome in the circumstances. ${ }^{362}$ Moreover, had the majority followed the prevalent view under international law regarding the supremacy of treaties in delimitation disputes, it would likely have been forced to decide on the basis of the 1906 agreement, which may have led it back to a situation of non licet. ${ }^{363}$ Therefore, the majority's flexible approach to the application of international legal principles, while perhaps not contributing much to their development or force, was arguably necessary in order for the arbitrators to properly carry out their dual role as "judges" and render a decision that would effectively resolve the question submitted to them.

In summary, the arbitrators arguably recognized the two dimensions of the arbitral process, and carried out their dual role as "judges" and "diplomats" as broadly and flexibly as possible within the narrow confines of the Arbitration Agreement. While the arbitrators could have focused on their role as "judges" and exercised it rigidly by not choosing one party's position over the other and refusing to render an award, as advocated in Prof. Lapidoth's dissent, such a result would have left the disputed question unresolved and potentially caused further friction and deterioration in the parties' broader peace process. Therefore, while the majority's interpretation of the Arbitration Agreement may be seen as "illogical" at times and it may be charged with exceeding its jurisdiction, ${ }^{364}$ such criticism arguably emanates from the modern one-dimensional perception of arbitrators as "judges" interpreting and applying strict legal principles, and is therefore misplaced. The majority's contextual and two-dimensional view of its own role was arguably necessary in order for the arbitration to effectively settle the dispute, and facilitated its success in doing so.

\subsection{Conclusion}

On its face, sovereignty over a piece of desert territory $10 \mathrm{~km}^{2}$ in size seems relatively insignificant in light of the broader and more complex peace agreement concluded between Israel and Egypt, in which Israel agreed to return to Egypt an area $60,000 \mathrm{~km}^{2}$ in size that

\footnotetext{
${ }^{362}$ Weil, supra note 310 at 14-15.

${ }^{363}$ Ibid at 24.

${ }^{364}$ Lapidoth, "Reflections", supra note 301 at 247.
} 
included oil wells and infrastructure of roads, military bases and airfields. ${ }^{365}$ However, the severity of a territorial dispute is arguably assessed in subjective terms, and may be motivated by psychological considerations without necessarily conforming to the "value" of the territory in objective terms. ${ }^{366}$ It is therefore not necessary for vital interests to be at stake for a territorial dispute to become politicized and threaten peace and stability. "Status politics" and "prestige contests" between states can easily translate into conflicts over territory, ${ }^{367}$ and, as this case illustrates, the two-dimensional nature of interstate arbitration can be effectively employed also in these instances to resolve territorial disputes involving a long history of violent conflict.

The arbitration in this case, however, constitutes in many respects only a partial success due to the parties' one-dimensional view of the arbitral process. First, as "poor questions can only receive poor answers", ${ }^{368}$ the narrow question submitted to the arbitral tribunal in this case and the manner in which it was submitted resulted in many disputed issues remaining unresolved, although the arbitration arguably laid the foundation for further negotiations on these issues. Had the parties fully accepted the concept of "conciliatory arbitration" and the "diplomatic" dimension of the arbitral process, and allowed the arbitrators to act as "diplomats" and devise a binding compromise with regard to all aspects of the Taba dispute, they could have arguably been spared the considerable time and effort spent on subsequent negotiations.

Second, although eventually the arbitral award was implemented by the parties, the initial Israeli response to it was negative, and could have easily led to further friction and deterioration in the already fragile relationship between the parties. While the parties presumably intended to protect their broader peace process by submitting only a narrow legal question to arbitration and severely limiting the arbitral tribunal's powers, this narrow approach instead exposed the peace negotiations to unnecessary risk. Moreover, had the circumstances been different, for instance had Taba been more strategically important, ${ }^{369}$ this approach may have led to the ultimate failure of the arbitral process, leaving the parties with no solution to this contested issue.

Finally, this case arguably exhibits several problematic features that, if taken out of the specific and a-typical context of this dispute, may set a bad precedent for states in future interstate

\footnotetext{
${ }^{365}$ Kemp \& Ben-Eliezer, supra note 298 at 315-316; Lagergren, supra note 302 at 525.

${ }^{366}$ Dinstein, supra note 314 at 59.

${ }^{367}$ Kemp \& Ben-Eliezer, supra note 298 at 318.

${ }^{368}$ Weil, supra note 310 at 25.

${ }^{369}$ Reisman, "Reflections", supra note 23 at 41.
} 
territorial arbitrations. ${ }^{370}$ The restrictions imposed on the arbitral tribunal by the parties resulted in what has been considered by some, including the dissenting arbitrator, to be a somewhat illogical and inconsistent award rendered by the tribunal in an effort to remain within the strict limits of the Arbitration Agreement. ${ }^{371}$ The parties' one-dimensional and legalistic approach to the arbitrators' role and the nature of the arbitral process also resulted in a zero-sum outcome favouring the position of one party almost to the exclusion of the other, even though the tribunal found both positions largely unacceptable.

On the other hand, this case also makes some positive contributions to the practice of interstate arbitration that also reinforce its two-dimensional nature. These include the parties' choice of non-judges to act as arbitrators; the national, cultural, and ethnic diversity of the members of the tribunals; and the flexible two-dimensional approach of the tribunal, which enabled it to resolve the disputed issue despite the constraints placed on it by the parties and to render an award that was ultimately implemented by the losing party. This case unfortunately remains the only instance where a dispute between an Arab state and Israel was submitted to arbitration, ${ }^{372}$ and had it not taken place, even in the limited form that it did, "the Taba problem would have remained unresolved indefinitely". 373

\section{The Red Sea Islands Arbitration, 1998}

\subsection{Background}

The islands and island groups located in the Southern end of the Red Sea ("Red Sea Islands" or "Islands") were the subject of a violent dispute between Eritrea and Yemen lasting from 1995 to 1998. Historically, the islands were part of the Ottoman Empire and its successor state, Turkey, from the mid-1800s until 1915. After its defeat in World War I, Turkey renounced its sovereignty over the Islands in the 1923 Treaty of Lausanne with the Allied forces, leaving them with "an objective legal status of indeterminacy":374

\footnotetext{
${ }^{370}$ Copeland, supra note 5 at 3084.

${ }^{371}$ Weil, supra note 310 at 23.

${ }^{372}$ Lapidoth, supra note 301 at 224.

${ }^{373}$ Lauterpacht, supra note 296 at 450.

${ }^{374}$ Constance Johnson, "Eritrea-Yemen Arbitration" (2000) 13:2 Leiden J Int'l L 427 at 431 [Johnson, "EritreaYemen"]; Queneudec, supra note 171 at 9; Jeffrey A. Lefebvre, "Red Sea Security and the Geopolitical-Economy of the Hanish Islands Dispute" (1998) 52(3) The Middle East Journal 367 at 369-370 [Lefebvre].
} 
Turkey hereby renounces all rights and title whatsoever over or respecting the territories situated outside the frontiers laid down in the present Treaty and the islands other than those over which her sovereignty is recognized by the said Treaty, the future of those territories and islands being settled or to be settled by the parties concerned... ${ }^{375}$

In 1962, an international agreement concerning the management of certain lighthouses in the Red Sea was adopted by the principal users of the Suez Canal, however it also did not define the legal situation of the Islands, which remained undetermined, and until the termination of this agreement in 1990 it was not possible to acquire any territorial title over the Red Sea Islands. At this point, the "interested parties" became the states bordering on the Red Sea, including Yemen and Ethiopia, which assumed the international responsibilities concerning navigation in the area. $^{376}$

After gaining independence from Ethiopia in 1993, Eritrea proceeded to claim sovereignty over the Islands, which claim was disputed by Yemen. In 1995, after negotiations failed to resolve the dispute, a full scale battle erupted threatening to escalate into an Arab-African conflict. Mediation attempts by several states and international organizations, including the United Nations, led to a cease fire. In May 1996, Eritrea and Yemen signed an Agreement on Principles in which they agreed to settle their dispute peacefully by arbitration. Concurrently with the Agreement on Principles, the Parties issued a brief Joint Statement, emphasizing their desire to settle the dispute, and "to allow the reestablishment and development of a trustful and lasting cooperation between the two countries", contributing to stability and peace in the region. ${ }^{377}$

The parties' dispute concerned territorial sovereignty over the Islands, the definition of their maritime boundary, and related rights to tourism, fishing, minerals, and oil. For both Eritrea and Yemen, two of the world's poorest countries, these issues were directly linked to national economic development as well as to perceptions of national honour, thereby magnifying their significance. The Islands were also of great strategic importance to the parties since they were situated along central shipping lanes and in an area of possible oil reserves, and the dispute therefore raised concerns about a possible threat to international navigation. ${ }^{378}$

\footnotetext{
${ }^{375}$ Treaty of Lausanne, Art. 16, as cited in Eritrea v Yemen (1998) Award of the Arbitral Tribunal in the First Stage of the Proceedings (Territorial Sovereignty and Scope of the Dispute) at para. 157 [Red Sea Islands First Award].

${ }^{376}$ Queneudec, supra note 165 at 9; Lefebvre, supra note 374 at 370.

${ }^{377}$ Red Sea Islands First Award, supra note 375 at para. 3.

${ }^{378}$ Bercovith \& Fretter, supra note 6 at 108; J.G. Merrills, "Reflections on Dispute Settlement in the Light of Recent Arbitrations Involving Eritrea" in Aristotle Constantinides \& N. Zaïkos, The Diversity of International Law: Essays
} 


\subsection{The arbitration agreement and procedure}

In October 1996, the parties concluded an arbitration agreement ("Arbitration Agreement"), which provided for a five-member arbitral tribunal, each party appointing two arbitrators, who were to appoint the President of the tribunal in cooperation with the parties. Should the partyappointed arbitrators fail to agree on a President, the Arbitration Agreement provided that the President shall be appointed by the President of the International Court of Justice in consultation with the party-appointed arbitrators. ${ }^{379}$

The Arbitration Agreement further provided that the tribunal was to decide "in accordance with international law" ${ }^{380}$ in two stages. The first stage concerned the definition and scope of the dispute, to be decided "on the basis of the respective positions of the two Parties", and territorial sovereignty, to be decided "in accordance with the principles, rules and practices of international law applicable to the matter, and on the basis, in particular, of historic titles". ${ }^{381}$ The second stage concerned the delimitation of maritime boundaries, and was to be decided "taking into account the opinion that [the tribunal] will have formed on questions of territorial sovereignty, the United Nations Convention on the Law of the Sea, and any other pertinent factor". 382

In accordance with the Arbitration Agreement, Eritrea appointed as arbitrators ICJ President Stephen Schwebel (U.S.A.) and ICJ judge Rosalyn Higgins (Britain), while Yemen appointed Ahmed Sadek El-Kosheri (Egypt) and Keith Highet (U.S.A.), both leading international counsel.

in Honour of Professor Kalliopi K. Koufa (Leiden; Boston: Martinus Nijhoff Publishers, 2009) at 109-110 [Merrills, "Reflections"]; Queneudec, supra note 165 at 2; Nuno Sérgio Marques Antunes, "The Eritrea-Yemen arbitration: First Stage - the Law of Title to Territory Re-Averred" (1999) 48:2 Int'l \& Comp LQ 362 at 362 [Antunes, "First Stage"]; Barbara Kwiatkowska, "Current Legal Developments-Red Sea: Award of the Arbitral Tribunal in the First Stage of the Eritrea/Yemen Proceedings" (1999) 14 Int'l J Marine \& Coastal L 125 at 126 [Kwiatkowska, "Current Legal Developments"]; Barbara Kwiatkowska, "The Eritrea-Yemen Arbitration: Landmark Progress in the Acquisition of Territorial Sovereignty and Equitable Maritime Boundary Delimitation" (2001) 32:1 Ocean Devel \& Int'l L 1 at 2 [Kwiatkowska, "The Eritrea-Yemen Arbitration"]; Spain, "Integration Matters", supra note 63 at 3738; Lefebvre, supra note 374 at 369, 372, 374-376.

${ }^{379}$ Arbitration Agreement (Eritrea and Yemen), 3 October 1996, Republic of Yemen National Information Centre, online: <http://www.yemen-nic.net/English\%20site/SITE\%20CONTAINTS/about\%20yemen/agreements/ Eritrea\% 20-\%20Yemen\%20Arbitration/Eritrea-Yemen\%20Award\%20phase\%202/ER-YEarbagree\%201.htm> at Article 1 [Red Sea Islands compromis].

${ }^{380}$ Ibid at Article 2(1).

${ }^{381}$ Ibid at Article 2(2).

${ }^{382}$ Ibid at Article 2(3). Interestingly, at the time Eritrea was not a party to the Convention on the Law of the Sea, Merrills, "Reflections", supra note 378 at 110; Queneudec, supra note 165 at 12. 
Pursuant to the joint recommendation of the parties, the four arbitrators appointed Sir Robert Jennings (Britain), former President of the ICJ, as President of the arbitral tribunal. ${ }^{383}$

\subsection{The parties' claims}

At the first stage of the proceedings, the arbitral tribunal was to determine the parties' respective territorial sovereignty over the Islands. ${ }^{384}$ Both Eritrea and Yemen claimed title to the Islands on the basis of both legal and non-legal factors. Both parties invoked historical evidence: the Ottoman Empire's long-lasting domination in the case of Yemen, and Italy's nineteenth-century colonial activity in the case of Eritrea. ${ }^{385}$ Yemen founded its claims on an "original, historic and traditional" ancient title preceding the Ottoman Empire, which, it asserted, "reverted" back to it when the Empire fell and Yemen became independent in 1918. It further claimed that the Treaty of Lausanne was res inter alios acta and had no effect on its title to the islands. ${ }^{386}$ Therefore, according to Yemen, despite its incorporation into the Ottoman Empire it has retained continuous title to the Islands on the basis of a "doctrine of reversion" and the principle of uti possidetis. ${ }^{387}$

Eritrea founded its claims on more recent historical grounds, following the demise of the Ottoman Empire. It argued that Italy had acquired title to the Islands by effective occupation after Turkey relinquished its sovereignty over them in the Treaty of Lausanne, rendering them

\footnotetext{
${ }^{383}$ Red Sea Islands First Award, supra note 375 at para. 4; Kwiatkowska, “The Eritrea-Yemen Arbitration”, supra note 378 at 2 .

${ }^{384}$ A preliminary issue to be determined by the arbitral tribunal was the scope of the dispute, and particularly whether the northern islands of Jabal al-Tayr and the Zubayr group ("Northern Islands") were to be included in the arbitration. With respect to the meaning of the expression "the respective positions of the parties" in the Arbitration Agreement, Yemen argued that this referred to the parties' positions regarding the scope of the dispute at the time the Agreement on Principles was concluded in 1996, and that, at that time, Eritrea had not claimed sovereignty over the Northern Islands. Therefore, Yemen claimed that these islands should be excluded from the arbitration. Eritrea, on the other hand, argued that the parties were "free to put forth and elaborate on their positions concerning the scope of the dispute at any point in the proceedings", and therefore that the claims contained in its submissions to the arbitral tribunal were sufficient to justify the inclusion of the Northern Islands in the arbitration. In deciding this question, the arbitral tribunal considered the "ordinary meaning" of the terms of the Arbitration Agreement, its object and purpose, and the fact that Yemen had included in its submissions arguments to support its claims to sovereignty over the Northern Islands. The tribunal concluded that these Islands were disputed at time the Arbitration Agreement was concluded, even if the parties may have held different positions earlier, when the Agreement on Principles was concluded. It therefore "prefer[red] the view of Eritrea" and included in the scope of the dispute "all the islands and islets with respect to which the parties have put forward conflicting claims". Red Sea Islands First Award, supra note 375 at paras. 75, 90; Antunes, "First Stage", supra note 378 at 364; Johnson, "Eritrea-Yemen", supra note 374 at 429-430; Merrills, "Reflections", supra note 378 at 111.

${ }^{385}$ Merrills, "Reflections", Ibid at 111; Antunes, "First Stage", supra note 378 at 365, Michael W. Reisman, "The Government of the State of Eritrea and the Government of the Republic of Yemen, Award of the Arbitral Tribunal in the First Stage of the Proceedings (Territorial Sovereignty and Scope of the Dispute)", Bernard H. Oxman, ed, International Decisions (1999) 93 Am J Int'l L 668 at 669 [Reisman, "International Decisions"].

${ }^{386}$ Red Sea Islands First Award, supra note 375 at para. 99.

${ }^{387}$ Ibid at paras. 96, 118; Antunes, "First Stage", supra note 378 at 365-367.
} 
res nullius. According to Eritrea, Ethiopia had succeeded this title in 1952 and as a result of Eritrea's secession from Ethiopia it then succeeded the Ethiopian legal position with respect to the Islands. ${ }^{388}$

In making their respective historical and legal claims, the parties relied on evidence of state and governmental authority, as well as use and possession they had allegedly exercised over the Islands, ${ }^{389}$ and both parties incorporated concepts of "contiguity", "appurtenance", 390 and "unity of islands and archipelagos" in their submissions. According to Yemen, the principle of natural or geographical unity was a "corollary of the concept of traditional title", ${ }^{391}$ while Eritrea referred to the "leapfrogging" method to support its argument of contiguity. ${ }^{392}$

In the second stage of the proceedings, the issue to be determined by the arbitral tribunal was the location of the maritime boundary. ${ }^{393}$ The parties' arguments at this stage were largely of a legal nature and concerned the interpretation of the international law principle of equidistance. ${ }^{394}$

\footnotetext{
${ }^{388}$ Red Sea Islands First Award, supra note 375 at paras. 13-30.

389 Johnson, "Eritrea-Yemen", supra note 374 at 432-433.

${ }^{390}$ According to which "any islands off one of the coasts may be thought to belong by appurtenance to that coast unless the state on the opposite coast has been able to demonstrate a clearly better title", Red Sea Islands First Award, supra note 375 at para. 458.

${ }^{391}$ Ibid at para. 35; Antunes, "First Stage", supra note 378 at 377.

${ }^{392}$ According to which "a chain of islands linked to the mainland with gaps no wider than twelve miles falls entirely within the coastal state's territorial sea and therefore under its territorial sovereignty", Red Sea Islands First Award, supra note 375 at para. 25; Antunes, "First Stage", supra note 378 at 377.

${ }^{393}$ Eritrea and Yemen were geographically opposite states, with Eritrea to the west and Yemen to the East, and their mainland coasts ran gradually apart from each other from south to north. The presence of the Islands in various locations, both near the coasts of the parties and in mid-sea, was a key geographic consideration in the delimitation. Given this diverse location and the configuration of the Red Sea, the delimitation in the south and parts of the middle sectors divided only territorial waters, while in the north the delimitation divided continental shelf and exclusive economic zones. Nuno Sérgio Marques Antunes, "The 1999 Eritrea-Yemen Maritime Delimitation Award and the Development of International Law" (2001) 50:2 Int'l \& Comp LQ 299 at 317-318 [Antunes, "Maritime Delimitation"]; Reisman, Michael W. "Eritrea-Yemen Arbitration (Award, Phase II: Maritime Delimitation)", Bernard H. Oxman, ed, International Decisions (2000) 94 Am J Int'l L 721 at 723 [Reisman, "Eritrea-Yemen"].

${ }^{394}$ Yemen claimed "one single international boundary line for all purposes", based on a division of the delimitation areas into three parts: "northern", "central", and "southern". According to Yemen, in the "northern" part, the Islands' base points of both sides should be treated equally because they each possessed islands of comparable size lying at similar distances from their respective mainland. As for the "central" part, Yemen argued that Eritrea's Haycock Islands were mere "navigational hazards" and therefore "inappropriate for a delimitation role" and entitled only to be considered as "limited enclaves". In the south, Yemen's claim was based on a simple equidistance line between the parties' mainland coasts. In contrast, Eritrea claimed that a distinction should be drawn between delimiting areas of continental shelf and exclusive economic zones in the north, and areas of territorial seas in the center. According to Eritrea, in the northern area Yemen's "small northern mid-sea islets" should not be taken into account, while in the center its Haycock Islands should be considered in applying the equidistance principle since Yemen's proposed solution would render both shipping channels within Yemen's territorial waters. Eritrea's alternative solution was based on what it considered to be the "historical median line", an equidistance line between the respective mainland coasts that gave effect to some of Eritrea's "historically owned islands" but disregarded completely Yemen's "recently acquired" mid-sea islands, as well as on the establishment of a "resource box system" that confined the Islands in certain 'boxes' that would become joint resource areas. Eritrea v Yemen (1999) Award
} 


\subsection{The arbitral tribunal's decision making process}

The arbitrators adopted a broad, flexible, and two-dimensional approach to the resolution of the parties' dispute, recognizing both the "legal" and "diplomatic" dimensions of the arbitral process and their own role as both "diplomats" and "judges".

\subsubsection{First stage}

Dealing first with the parties' historical and legal arguments, the tribunal found that in order to establish title the parties had to prove both continuity and passage of time. ${ }^{395}$ The tribunal interpreted Article 16 of the Treaty of Lausanne as covering all the contested Islands ${ }^{396}$ and rejected Yemen's assertion that the Treaty was res inter alios acta, noting that while "boundary and territorial treaties made between two parties are res inter alios acta vis-à-vis third parties...this special category of treaties also represents a legal reality which necessarily impinges upon third states, because they have effect erga omnes". 397

The tribunal also rejected Yemen's claim to a "reversion of title", doubting that it was a valid principle of international law, ${ }^{398}$ and finding that, in any event, "the concept of territorial sovereignty was entirely strange" to Yemen during the time of the Ottoman Empire and that it was questionable whether Yemen possessed sovereignty over the Islands prior to this time. ${ }^{399}$ Therefore, the tribunal concluded that Yemen could not claim ancient title due to lack of continuity. ${ }^{400}$ While the tribunal also doubted whether the doctrine of uti possidetis, "at that time thought of as being essentially one applicable to Latin America, could properly be applied to interpret a juridical question arising in the Middle East shortly after the close of the First World War", ${ }^{401}$ it did apply a form of this doctrine by finding that "when the whole region was under Ottoman rule it was assumed that the powers of juris diction and administration over the islands

of the Arbitral Tribunal in the Second Stage of the Proceedings (Maritime Delimitation) at paras. 17, 114 [Red Sea Islands Second Award]; Antunes, "Maritime Delimitation", supra note 393 at 318-319; Malcolm D. Evans, "The Maritime Delimitation Between Eritrea and Yemen” (2001) 14:1 Leiden J Int'l L 141 at 152-153 [Evans];

${ }^{395}$ Red Sea Islands First Award, supra note 375 at para. 106; Queneudec, supra note 165 at 8.

${ }^{396}$ Red Sea Islands First Award, Ibid at para. 163; Reisman, "International Decisions", supra note 385 at 670.

${ }^{397}$ Red Sea Islands First Award, Ibid at para. 153.

398 Ibid at paras. 125, 443; Johnson, "Eritrea-Yemen", supra note 374 at 433-434.

${ }^{399}$ Red Sea Islands First Award, supra note 375 at para. 143.

${ }^{400}$ Ibid at paras. 144, 443; Antunes, "First Stage", supra note 378 at 367-368; Johnson, "Eritrea-Yemen", supra note 374 at $434-435$.

${ }^{401}$ Red Sea Islands First Award, supra note 375 at para. 99. 
should be divided between the two opposite coasts", 402 and that this was a historic fact that should be given "a certain legal weight". 403

With respect to Eritrea's claims to Italian sovereignty on the basis of res nullius, the tribunal read Article 16 of the Lausanne Treaty as follows:

In 1923, Turkey renounced tide to those islands over which it had sovereignty until then. They did not become res nullius - that is to say, open to acquisitive prescription - by any state, including any of the High Contracting Parties (including Italy). Nor did they automatically revert (insofar as they had ever belonged) to the Imam [Yemen]. Sovereign title over them remained indeterminate pro tempore. ${ }^{404}$

Accordingly, the tribunal found that Italy had not acquired valid title to the Islands at any point in time, and therefore such title could not have been transferred to Eritrea through Ethiopia. ${ }^{405}$ Concluding that neither party was able to establish historic title to the Islands, ${ }^{406}$ the tribunal turned to evidence of "demonstration of use, presence, display of governmental authority, and other ways of showing a possession which may gradually consolidate into a title". 407

The tribunal divided this evidence into four categories of effectivités ${ }^{408}$ : "assertion of intention to claim the islands", "activities relating to the water", "activities on the islands", and "general activities". ${ }^{409}$ Within these categories the parties presented evidence relating to petroleum-related activities, ${ }^{410}$ the establishment and maintenance of lighthouses in the Red Sea, ${ }^{411}$ and cartographic evidence. ${ }^{412}$ Since these different types of evidence concerned different islands with different legal histories, and may therefore lead to different results, the tribunal found that it could not consider the sovereignty of the Islands as a whole as claimed by the parties. ${ }^{413}$ Moreover, the tribunal found that this evidence revealed "a chequered and frequently changing

\footnotetext{
402 Ibid at para. 100.

${ }^{403}$ Ibid at paras. 126, 142; Reisman, "International Decisions", supra note 385 at 669.

${ }^{404}$ Red Sea Islands First Award, supra note 375 at para. 165; Reisman, "International Decisions”, Ibid at 671.

${ }^{405}$ Red Sea Islands First Award, Ibid at paras. 169-186, 448; Johnson, "Eritrea-Yemen”, supra note 374 at 435-436.

${ }^{406}$ Red Sea Islands First Award, Ibid at paras. 447-449.

407 Ibid at para. 450.

408 These reflect "continuous and peaceful display of the functions of state", Ibid at para. 451; Antunes, "First Stage", supra note 378 at 371-372.

${ }^{409}$ Red Sea Islands First Award, supra note 375 at para. 240 et seq; Antunes, "First Stage", supra note 378 at $373-$ 374; Johnson, "Eritrea-Yemen", supra note 374 at 438-439; Kwiatkowska, "Current Legal Developments", supra note 378 at 133 .

${ }^{410}$ Red Sea Islands First Award, supra note 375 at paras. 389-439.

411 Ibid at paras. 200-238.

${ }^{412}$ Ibid at paras. 362-388.

${ }^{413}$ Ibid at para. 459.
} 
situation", and that since "the activities relied upon by the parties, though many, sometimes speak with an uncertain voice, it is surely right for the Tribunal to consider whether there are in the instant case other factors which might help to resolve some of these uncertainties". 414

The tribunal therefore proceeded to consider such "other factors", and divided the Islands into four sub-groups, assigning them individually to one or other of the parties based on the "portico doctrine", ${ }^{415}$ and principles of appurtenance or proximity, and unity. ${ }^{416}$ Finally, the arbitral tribunal recognized that "intertwined with the question of sovereignty was the problem of the immemorial access to fishing resources by fishermen from both States", and therefore stated that in exercising its sovereignty over certain islands, Yemen was to ensure "that the traditional fishing regime of free access and enjoyment for the fishermen of both Eritrea and Yemen shall be preserved". ${ }^{417}$ In the dispositif, the tribunal therefore decreed that "the sovereignty found to lie within Yemen entails the perpetuation of the traditional fishing regime in the region, including free access and enjoyment for the fishermen of both Eritrea and Yemen". 418

\subsubsection{Second stage}

The second stage of the proceedings mainly dealt with the location of the maritime boundary. However, the tribunal first addressed in greater detail its ruling in the first stage regarding the

\footnotetext{
${ }^{414}$ Ibid at paras. $456-457$.

415 According to which control established over one of the mainland coasts should be considered to continue to islands or islets off that coast which are naturally "proximate" to the coast or "appurtenant" to it, Ibid at para. 463; Antunes, "First Stage", supra note 378 at 377-378; Johnson, "Eritrea-Yemen", supra note 374 at 437-438.

${ }^{416}$ With respect to the first sub-group, the Mohabbakahs Islands located in or near Eritrea's territorial sea, the tribunal considered that since "no convincing alternative title" to these islands was shown by Yemen to rebut the principle that "islands within the territorial sea of a state were to belong to that state", they belonged to Eritrea. With respect to the second sub-group, the Haycocks Islands, the tribunal noted their historical connection with African jurisdiction during the Ottoman rule as well as some evidence of Italian presence, but ultimately also relied on geographical proximity to the Eritrean mainland coast for granting sovereignty over these islands to Eritrea. With respect to the third sub-group, the Zuqar-Hanish Group located in the central part of the Red Sea, the tribunal found historical and cartographical evidence to be inconclusive, and relied instead on recent evidence of governmental authority, including lighthouses, naval patrols, and petroleum agreements. The tribunal referred to Yemen's presence, display of authority, "widespread repute" regarding these islands, and its effective presence in them and concluded that, although there was also some evidence supporting Eritrea's claims, Yemen's claim was stronger. With respect to the fourth sub-group, Jabal al-Tayr Island and the Zubayr Group, which were more isolated, the tribunal accepted that there was "little evidence" of governmental authority and found the construction and maintenance of lighthouses by Yemen, its conclusion of petroleum agreements, and the legal history of these islands to favour Yemen. Red Sea Islands First Award, supra note 375 at paras. 472, 476-507, 509-524; Antunes, "First Stage", supra note 378 at 378, 380-382; Evans, supra note 394 at 142-144; Johnson, "Eritrea-Yemen", supra note 374 at 441-445; Merrills, "Reflections", supra note 378 at 111-112; Queneudec, supra note 165 at 12.

${ }^{417}$ Red Sea Islands First Award, supra note 375 at para. 526.

${ }^{418}$ Ibid at para. 527 (vi).
} 
preservation of "the traditional fishing regime", ${ }^{419}$ since the parties differed in their interpretation of this ruling. The tribunal viewed this regime as rooted in the Islamic heritage of the area and in the legal rules contained in the Qur'an, and considered it most relevant that "fishermen from both of these nations had, from time immemorial, used these islands for fishing and activities related thereto". ${ }^{420}$ Eritrea claimed that this "traditional fishing regime" required the establishment of joint resource zones which the tribunal should delimit, and that the tribunal should "specify with precision what was entailed by its finding as to the traditional fishing regime". ${ }^{421}$ Yemen, on the other hand, argued that its sovereignty over the Islands was not made conditional by the tribunal's ruling, that it alone was to ensure the preservation of traditional fishing rights, that no agreement with Eritrea was required, and that the tribunal's finding was in favour of fishermen of the two countries, not only Eritrea. ${ }^{422}$

The tribunal clarified in this regard that the sovereignty over the Islands awarded to Yemen was not "conditional", but was rather sovereignty that "respect[ed] and embrace[d] and [wa]s subject to the Islamic legal concepts of the region...precisely because classical western territorial sovereignty would have been understood as allowing the power in the sovereign State to exclude fishermen of a different nationality from its waters". ${ }^{423}$ The traditional fishing regime was therefore "one of free access and enjoyment for the fishermen of both Eritrea and Yemen" but Eritrea could act for its nationals "through diplomatic contacts with Yemen or through submissions to this Tribunal". ${ }^{424}$ Moreover, the tribunal rejected Eritrea's claim to joint resource areas by stating that this "regime is not an entitlement in common to resources nor is it a shared right in them". 425

The tribunal then described the activities encompassed by the fishing regime; who was entitled to benefit from them; and where they could be carried out. ${ }^{426}$ It stated that both Eritrean and

\footnotetext{
${ }^{419}$ Red Sea Islands Second Award, supra note 394 at paras. 87-112.

${ }^{420} \mathrm{Ibid}$ at para. 95. The reference to the rules of the Qur'an has been attributed to arbitrator El-Koseri, Antunes, "Maritime Delimitation", supra note 393 at 302.

${ }^{421}$ Red Sea Islands Second Award, supra note 394 at para. 89.

${ }^{422}$ Ibid at paras. 37, 90; Antunes, "Maritime Delimitation", supra note 393 at 301-302; Reisman, "Eritrea-Yemen", supra note 393 at 722.

${ }^{423}$ Red Sea Islands Second Award, supra note 394 at paras. 94-95.

${ }^{424}$ Ibid at para. 101.

${ }^{425}$ Ibid at para. 103.

${ }^{426}$ Ibid at paras. 103-109.
} 
Yemeni fishermen were entitled "to engage in artisanal fishing around the islands", 427 and that the regime covered "those entitlements that all fishermen have exercised continuously through the ages", including "to enter the relevant ports, and to sell and market fish there", and was not restricted "by the maritime zones specified under" UNCLOS or the international maritime boundary decided by the tribunal. ${ }^{428}$

Although the fishing regime was not to limit Yemen's competence to regulate either the fishing activities of nationals of third states or industrial fishing activities by Eritreans, it was to limit its competence to regulate the traditional fishing regime and to enact environmental measures that could affect that regime, which from now on could be taken only "with the agreement of Eritrea". ${ }^{429}$ The parties were also to "inform one another and to consult one another on any oil and gas and other mineral resources that may be discovered that straddle the single maritime boundary between them or that lie in its immediate vicinity" and to "give every consideration to the shared or joint or unitised exploitation" of resources that straddle maritime boundaries". 430 This traditional fishing regime, however, was to have no bearing on the determination of the maritime boundary line. ${ }^{431}$

With regard to this determination, the tribunal again combined the "legal" and "diplomatic" dimensions of arbitration to produce a legally sound, but also pragmatic and fair, solution to the parties' dispute. While the parties based their arguments in this regard largely on principles of international law, and the tribunal recognized that the Arbitration Agreement referred to UNCLOS and did not mention customary law, it found that some of the articles of UNCLOS included a number of relevant customary elements, "were consciously designed to decide as little as possible", and "envisage[d] an equitable result", ${ }^{432}$ and therefore turned to customary law of the sea. Moreover, the term "other pertinent factors" in the Arbitration Agreement was interpreted by the tribunal to be a "broad concept" that included "various factors that are generally recognised as being relevant to the process of delimitation such as proportionality, non-

\footnotetext{
427 "Artisanal fishing" was interpreted broadly by the tribunal to include diving for shells and pearls and related traditional activities such as drying fish, Ibid at para. 103; Antunes, "Maritime Delimitation", supra note 393 at 303, fn 14.

${ }^{428}$ Red Sea Islands Second Award, supra note 394 at paras. 104, 107, 110; Antunes, "Maritime Delimitation", supra note 393 at 303-304; Kwiatkowska, "The Eritrea-Yemen Arbitration", supra note 378 at 13.

${ }_{429}$ Red Sea Islands Second Award, supra note 394 at paras. 108; Reisman, "Eritrea-Yemen”, supra note 393 at 723.

${ }^{430}$ Red Sea Islands Second Award, Ibid at para. 86.

${ }^{431}$ Reisman, "Eritrea-Yemen", supra note 393 at 725.

${ }^{432}$ Red Sea Islands Second Award, supra note 394 at para. 116.
} 
encroachment, the presence of islands, and any other factors that might affect the equities of the particular situation". 433

The basic notion guiding the tribunal's ultimate determination of the maritime boundary was that a single all-purpose boundary was to be delimited, which "as far as practicable, [should] be a median line between the opposite mainland coastlines". ${ }^{434}$ This finding was based on both legal and non-legal factors, including the "generally accepted view" that in cases such as this "the median or equidistance line normally provides an equitable boundary"; the fact that such a line was in accordance with the requirements of the Convention; and the fact that both parties relied on the equidistance method "although based on different points of departure". ${ }^{435}$ In deciding the location of the maritime boundary line, the tribunal also took into account international navigation interests, referred to by the parties in the preamble of the Arbitration Agreement as "their responsibilities toward the international community as regards...the safeguard of the freedom of navigation in a particularly sensitive region of the world". ${ }^{436}$ The tribunal also assessed the equitableness of the equidistance boundary in accordance with the test of "a reasonable degree of proportionality", which both parties agreed meant that the division of waters was to be proportional to the lengths of their respective coasts but differed on how these lengths should be calculated. ${ }^{437}$ Finally, the tribunal considered the possible claims of neighbouring states, namely Saudi Arabia in the north and Djibouti in the south, and while

\footnotetext{
${ }^{433}$ Ibid at para. 130; Queneudec, supra note 165 at 13; Antunes, "Maritime Delimitation", supra note 393 at 320; Evans, supra note 394 at 148-149.

${ }^{434}$ Red Sea Islands Second Award, supra note 394 at para. 132; Antunes, "Maritime Delimitation”, supra note 393 at 320 .

${ }^{435}$ The median line ultimately drawn by the tribunal, however, largely followed a different course from the lines proposed by the parties. In the northern part of the boundary, the arbitral tribunal considered factors such as "size, importance and like considerations in the general geographical context" and found that an equitable result required that Yemen's mid-sea islands be treated differently from Eritrea's islands due to their far location and barren nature, and that they should not be considered in the calculation of the equidistance boundary. In the central part of the boundary, the tribunal found that the parties' territorial waters overlapped and rejected Yemen's "enclave solution", which it found to be "impractical" in light of the vicinity of a major international shipping route, as well as potentially interfering with Eritrea's rights and security. The tribunal decided instead on a mainland coastal median, which cut through the area of overlap of the territorial seas of the parties and created a "neater and more convenient international boundary". In the southern part of the boundary, as there were no mid-sea islands, there were few differences between the parties' equidistance lines and the line determined by the tribunal attempted to reflect the desirability of "simplicity in the neighbourhood of a main shipping lane". Red Sea Islands Second Award, supra note 394 at paras. 113-120, 124-125, 127-128, 131, 147-153, 154-159, 162-163; Antunes, "Maritime Delimitation", supra note 393 at 320-321, 324; Kwiatkowska, "The Eritrea-Yemen Arbitration", supra note 378 at 8, 10; Merrills, "Reflections", supra note 378 at 112-113; Evans, supra note 394 at 154-157.

${ }^{436}$ Red Sea Islands compromis, supra note 379, Preamble.

${ }^{437}$ Red Sea Islands Second Award, supra note 394 at paras. 39-43, 117, 165-168; Antunes, "Maritime Delimitation", supra note 393 at 338-339; Evans, supra note 394 at 163-165; Kwiatkowska, "The Eritrea-Yemen Arbitration", supra note 378 at $10-11$.
} 
noting that it did not have authority to decide such claims it reached a compromise between their positions and that of the parties, particularly Yemen. ${ }^{438}$

\subsection{The outcome of the arbitration}

The first award rendered by the arbitral tribunal was praised for achieving "a well-struck balance between individual justice in casu and the need for predictability demanded by 'international society", as well as taking due account of the parties' aspiration to "allow the re-establishment and the development of a trustful and lasting co-operation" between them. ${ }^{439}$ Both states expressed their intention to abide by the award and Eritrea proceeded to withdraw its forces from the islands awarded to Yemen in the arbitration. ${ }^{440}$ The parties also signed the Treaty Establishing the Joint Yemeni-Eritrean Committee for Bilateral Cooperation of 16 October 1998, which testified to the restoration of friendly relations between the parties. ${ }^{441}$

The findings of the arbitral tribunal in the second award were accepted by both parties as "balanced". ${ }^{442}$ Eritrea stated that the settlement of the dispute "will not only pave the way for a harmonious relationship between the littoral states of the Red Sea, but also opens a new window of opportunity for the consolidation of peace and stability in the region and the creation of a zone of peace, development and mutual benefit", while Yemen stated that the award "represents a culmination of a great diplomatic effort and an important historic development in political and diplomatic relations between two neighbouring countries" and "a way that should be followed for resolving Arab, regional and international disputes". 443

\subsection{Analysis}

As in the Beagle Channel and Taba cases, both the parties' perception of the arbitration and the arbitral tribunal's reasoning and approach to its own role arguably shaped the outcome of the Red Sea Islands arbitration. Unlike in the previous two cases, however, the parties' and the arbitral tribunal's recognition of the "diplomatic" and "legal" dimensions of the arbitral process

\footnotetext{
${ }^{438}$ Red Sea Islands Second Award, supra note 394 at paras. 44-46, 136, 164; Antunes, "Maritime Delimitation", supra note 393 at 325, 340; Evans, supra note 394 at 165-166.

439 Antunes, "First Stage", supra note 378 at 384.

${ }^{440}$ Ibid.

${ }^{441}$ Kwiatkowska, "The Eritrea-Yemen Arbitration”, supra note 378 at 2.

${ }^{442}$ Antunes, "Maritime Delimitation", supra note 393 at 341; Queneudec, supra note 165 at 1.

${ }^{443}$ Spain, "Integration Matters", supra note 63 at 40; Kwiatkowska, “The Eritrea-Yemen Arbitration", supra note 378 at 3.
} 
and the proper exercise of their dual role in this case arguably contributed to the successful resolution of the parties' conflict.

\subsubsection{The parties}

The parties' two-dimensional perception of the arbitration process as designed to resolve multiple aspects of their dispute and produce an equitable result can arguably be deduced from the language and scope of the Arbitration Agreement; the constitution of the arbitral tribunal and the relatively broad authority granted to it; and, ultimately, from the parties' prompt acceptance of the arbitral award although it was not based solely on international law principles.

Notably, the parties exercised their right to appoint arbitrators of their choice, and the arbitral tribunal included both current and past ICJ judges and non-judges, one of whom, Dr. El-Kosheri, was of Egyptian origins and "was brought up in the Islamic culture". 444 This balanced composition of the tribunal ensured both that international law would be adequately followed and applied, and that local circumstances such as the history of the dispute and the parties' culture, particular legal tradition, and underlying interests, would be accounted for. The composition of the tribunal may have contributed to its flexible legal approach in the First Award, applying novel concepts of land acquisition, and its consideration of extra-legal factors in delimiting the parties' maritime boundary in the Second Award. Moreover, the presence of Dr. El-Kosheri, who was familiar with the region and Islamic law, arguably contributed to the tribunal's consideration of local customs concerning fishing, and its incorporation of Islamic law in the protection of traditional fishing rights.

The two-dimensional approach of the parties is also evident in the Arbitration Agreement, which provided that the tribunal was to determine "territorial sovereignty...in accordance with the principles, rules and practices of international law...and...in particular, historic titles", and "maritime boundaries...taking into account the opinion that it will have formed on questions of territorial sovereignty, the United Nations Convention on the Law of the Sea, and any other pertinent factor". The parties therefore used broad and general language to define the issues to be determined, namely "territorial sovereignty" and "maritime boundaries", and, at least with respect to their maritime dispute, granted broad authority to the tribunal to take into account

${ }^{444}$ Antunes, "First Stage", supra note 378 at 385, fn 100. 
potentially extra-legal considerations, which may indicate their interest in avoiding a restrictive reading of UNCLOS. ${ }^{445}$

This broad language translated into flexibility and creativity in the arbitral tribunal's decision making, allowing it to allocate sovereignty over the islands based on varied considerations and in accordance with what it perceived to be best for the parties. ${ }^{446}$ On the other hand, the term "any other pertinent factor", was arguably not sufficiently clear, ${ }^{447}$ and although it was interpreted broadly by the tribunal as including "factors that might affect the equities of the particular situation", 448 the parties would have been well advised to use a clearer term such as "equitable factors" if they indeed intended to give such authority to the tribunal.

The Arbitration Agreement also illustrates how differences between state parties over the scope of the dispute, which are a "well-known obstacle to utilizing" interstate arbitration, ${ }^{449}$ can be overcome by allowing the arbitral tribunal to determine its own mandate. The parties in this case still maintained some degree of control by providing that such determination was to be made "on the basis of the respective positions of the two parties", although the meaning of this expression was itself disputed and left to be resolved by the tribunal. Rather than narrowly defining the scope of the dispute in the Arbitration Agreement, as was the case in the Beagle Channel arbitration, Eritrea and Yemen rightly granted the tribunal the authority to determine the precise scope of the dispute it was to decide, which likely also facilitated the conclusion of the Arbitration Agreement. ${ }^{450}$

In summary, the parties in this case submitted broadly framed issues to the arbitral tribunal, to be decided in accordance with international law as well as "other pertinent factors" by a panel consisting of both ICJ judges and non-judges. All this arguably suggests that the parties recognized, at least to some extent, both dimensions of the arbitration process, which enabled the arbitral tribunal to resolve all aspects of their dispute by applying both legal and extra-legal principles as appropriate. Nonetheless, the parties would have been well-advised to also explicitly authorize the tribunal to apply equitable principles or to decide ex aequo et bono.

\footnotetext{
${ }^{445}$ Reisman, "Eritrea-Yemen", supra note 393 at 728.

${ }^{446}$ Red Sea Islands First Award, supra note 375 at paras. 102, 454-455; Queneudec, supra note 165 at 7.

${ }^{447}$ Queneudec, Ibid at 13.

${ }^{448}$ Red Sea Islands Second Award, supra note 394 at para. 130.

${ }^{449}$ Merrills, "Reflections", supra note 378 at 111.

${ }^{450}$ Reisman, "International Decisions”, supra note 385 at 677.
} 
Fortunately, the arbitrators in this case were sufficiently flexible in their approach to the arbitral process and their own role as "diplomats" to incorporate such equitable considerations into their decision making sua sponte.

\subsubsection{The arbitral tribunal}

In additional to the parties' commendable approach to the arbitration process, the arbitral tribunal's two-dimensional reasoning and decision making also contributed to its successful resolution of the dispute.

Exercising their role as "judges" broadly and creatively, the arbitrators applied both flexible and innovative reasoning in the First Award, and traditional legal analysis in the Second Award. ${ }^{451}$ They incorporated both established international law and equitable considerations in their decision making and applied novel and creative reasoning where established international law failed to provide an adequate answer. ${ }^{452}$ The arbitrators also effectively invoked their role as "diplomats" by finding that their authority to decide "on territorial sovereignty" 453 allowed them to decide on related issues, such as the fishing rights of the Eritrean people around the islands awarded to Yemen. The arbitrators therefore did not restrict their own jurisdiction to the legal issues disputed by the parties, and considered also the parties' culture and tradition, which likely made the ultimate outcome of the arbitration easier for the parties to accept and implement. ${ }^{454}$

\footnotetext{
${ }^{451}$ Queneudec, supra note 165 at 3.

${ }^{452}$ In the First Award, for instance, the tribunal was faced with a novel situation in which neither recourse to legal title nor to effective occupation could provide the basis for the settlement of the territorial conflict. The tribunal found that Article 16 of the Treaty of Lausanne was biding erga omnes, severed any links of succession the parties may have relied on, and gave the islands an "indeterminate status" that could not be amended by subsequent action, and also that neither party could establish effective occupation of the disputed islands. Rather than issuing a decision non liquet as a result of this finding, however, the tribunal effectively created new law and "innovative prescriptions regarding territorial acquisition" by setting out a presumption of sovereignty based on geographical proximity that can be defeated only by a "fully-established case to the contrary" or another "superior title". Queneudec, supra note 165 at 10-11; Reisman, "International Decisions", supra note 385 at 678-679; Red Sea Islands First Award, supra note 375 at paras. 474,480 .

${ }^{453}$ Red Sea Islands compromis, supra note 379 at Article 2(2).

${ }^{454}$ In the First Award, for instance, the tribunal rejected Yemen's claim to "historic title" partially on the ground that it was inappropriate to attribute western concepts of sovereignty to a medieval Islamic society such as that which existed in the Yemen area at the time, Red Sea Islands First Award, supra note 375 at paras. 123, 143, 446; Johnson, "Eritrea-Yemen", supra note 374 at 434. Still, some argue that the tribunal did not go far enough in its departure from Eurocentric political-cultural notions since it continued to demand "socio-political power over the geographic area" in order to secure title, rather than applying a more "sensitive socio-ecological test" to these uninhabited islands and thereby recognizing and giving effect to forms of political organization that have evolved in ecologies different from those of Europe, Reisman, "International Decisions", supra note 385 at 681-682.
} 
Effectively utilizing the "legal dimension" of the arbitral process, the tribunal applied legal standards flexibly in its decision making, finding, for instance, that decisions should not be reached merely by balancing the relative strength of the parties' claims as presented, particularly "when looking at other possible factors might strengthen the basis of decision". ${ }^{455}$ In determining sovereignty over the islands, therefore, since the tribunal found that the evidence provided by the parties was inconclusive, it applied criteria that the Arbitration Agreement arguably did not authorize. ${ }^{456}$ As the tribunal stated:

[I]n order to make decisions on territorial sovereignty, the Tribunal has hardly surprisingly found no alternative but to depart from the terms in which both Parties have pleaded their cases, namely by each of them presenting a claim to every one of the islands involved in the case. The legal history simply does not support either such claim...[t]he Tribunal has accordingly had to reach a conclusion which neither Party was willing to contemplate, namely that the islands might have to be divided; not indeed by the Tribunal but by the weight of the evidence and argument presented by the Parties, which does not fall evenly over the whole of the islands but leads to different results for certain sub-groups, and for certain islands. ${ }^{457}$

Therefore, rather than confining itself to the legal arguments of the parties and a strict reading of the Arbitration Agreement, the tribunal departed from the parties' contemplated solution and devised an alternative one, which provided a just and fair allocation of sovereignty between the parties. ${ }^{458}$ At the same time, the tribunal took care to acknowledge evidence that supported the parties' contradictory claims to sovereignty, balanced "all relevant historical, factual and legal considerations", and noted its "greatest respect for the sincerity and foundations of the claims of both parties". 459

The arbitral tribunal also considered equity as part of international law in determining the parties' maritime boundary in the Second Award. Achieving an equitable result seemed to trump in the tribunal's view the strict application of the equidistance principle, as it preferred to "refashion geography" rather than producing an inequitable boundary in the northern mid-sea islands area. ${ }^{460}$ In addition, the tribunal relied on considerations of proportionality to assess the

\footnotetext{
${ }^{455}$ Red Sea Islands First Award, supra note 375 at paras. 452-457.

${ }^{456}$ Reisman, "International Decisions", supra note 385 at 674.

${ }^{457}$ Red Sea Islands First Award, supra note 375 at para. 466.

458 The tribunal proceeded to allocate the groups of islands between the parties by applying a variety of principles, such as proximity, shared "legal destiny", unity, and appurtenance. Ibid at para. 475

${ }^{459}$ Red Sea Islands First Award, Ibid at para. 508; Antunes, "First Stage", supra note 378 at 381.

${ }^{460}$ Antunes, "Maritime Delimitation", supra note 393 at 335.
} 
equitableness of the final delimitation decision, which allowed it to depart from the application of strict equidistance where it saw fit. ${ }^{461}$

In carrying out their role as "diplomats", the arbitrators went beyond the disputed issues submitted by the parties and considered the need to respect their "regional legal traditions", noting that "western ideas of territorial sovereignty are strange to peoples brought up in the Islamic tradition" and ruling that the parties were to maintain and perpetuate the traditional fishing regime which had existed around the disputed islands for many years. ${ }^{462}$ The tribunal thereby construed the Islamic tradition of territorial sovereignty as distinct from the corresponding Western ideas, and as antedating "the relatively modern, European-derived, concepts of exclusionary sovereignty". ${ }^{463}$ Although Islamic law was neither selected nor argued by the parties, the arbitral tribunal purported to use it as the basis for its elaboration of the continuing "artisanal fishing regime".

This approach has been criticized as "unwise in context" since "the essential function of general international law, as a secular corpus juris, is to provide a common standard and to play a mediating role between states with different cultures, legal systems, and belief systems". ${ }^{464}$ While this may indeed be the purpose of international law, it is questionable whether ad hoc arbitral tribunals, deciding a specific dispute between particular parties, would indeed be "well advised to stick to international law", 465 especially where, as here, the parties have included broad language in their Arbitration Agreement and allowed for the application of other "pertinent factors" as the tribunal sees fit. While inappropriate application of religious, or other, law not contemplated or authorized by the parties may indeed, in some cases, prove "mischievous, even pernicious", 466 applying legal norms shared by the parties that address significant aspects of their dispute that international law fails to adequately address, may also strengthen the legitimacy of the outcome in the eyes of the parties and facilitate its acceptance and implementation.

\footnotetext{
461 the proportionality test devised by the tribunal, while criticized as "legally meaningless" since it did not include any objective and standard criteria, was arguably not aimed at setting out "internationally defined objective criteria", but rather at achieving an equitable result between the parties, which it succeeded to do. Evans, supra note 394 at 165; Antunes, "Maritime Delimitation", supra note 393 at 338-339.

${ }^{462}$ Red Sea Islands First Award, supra note 375 at para. 525; Queneudec, supra note 165 at 6.

${ }^{463}$ Red Sea Islands Second Award, supra note 394 at paras. 85, 92-95; Red Sea Islands First Award, supra note 375 at para. 525; Kwiatkowska, "The Eritrea-Yemen Arbitration", supra note 378 at 11.

464 Reisman, "Eritrea-Yemen", supra note 393 at 729.

465 Ibid.

${ }^{466}$ Ibid.
} 
The issue of fishing rights, although also not explicitly submitted to the tribunal for determination, was of great importance to the parties, since it presented a potential source of income, generating jobs, food, and revenues from exports and from granting foreign fishing licenses. ${ }^{467}$ The fishing regime set out by the arbitral tribunal entitled fishermen from both states to freely practice traditional fishing in the waters surrounding the islands attributed to Yemen, independent of the international boundary, and granted to them related rights and privileges, such as free access to the islands and the right to sell catches in the ports of the other state. ${ }^{468}$ This fishing regime constituted a special legal order that was non-territorial in nature, "a transnational order of inter-individual dimensions", ${ }^{469}$ intended to "benefit of the lives and livelihoods of this poor and industrious order of men". ${ }^{470}$ While the tribunal arguably went beyond what the parties had intended it to decide upon and effectively limited their sovereignty, ${ }^{471}$ thereby challenging well-established notions of states' sovereign powers under international law, ${ }^{472}$ this was arguably justified in order to ensure the continued protection of the economic and cultural rights of fishermen from both countries. In devising the fishing regime the tribunal emphasized "human" over legal considerations, and although its legal foundation in international law was admittedly not entirely clear, the tribunal rationalized and described it in such a way that arguably did not compromise the overall reasonableness of its decision ${ }^{473}$ but rather reflected its desire to "deal fully with the issues before it and do justice to the parties' arguments". 474

As the tribunal's decision to limit the parties' sovereign rights respecting the fishing regime was not based on treaties in similar situations ${ }^{475}$ or on customary international law, ${ }^{476}$ it is arguably best seen as equitable in nature, reflecting the tribunal's consideration of the fairest result in light of the history and culture of the parties and in order "not to disturb the socio-economic reality of

\footnotetext{
${ }^{467}$ Lefebvre, supra note 374 at 374.

${ }^{468}$ Red Sea Islands Second Award, supra note 394 at paras. 103-107; Queneudec, supra note 165 at 6; Merrills, "Reflections", supra note 378 at 113.

${ }^{469}$ Queneudec, supra note 165 at 7.

${ }^{470}$ Red Sea Islands First Award, supra note 375 at para. 526.

${ }^{471}$ Antunes, "Maritime Delimitation", supra note 393 at 305.

${ }^{472}$ Ibid at 305, 307.

473 Ibid at 342.

${ }^{474}$ Merrills, "Reflections", supra note 375 at 117.

475 Antunes, "Maritime Delimitation", supra note 393 at 311.

${ }^{476}$ Although there are several possible legal foundations for this decision, such as viewing the traditional regime as lex specialis and the rules of international law as lex generalis; applying the principle of quieta non movere, i.e., that "a state of things which actually exists and has existed for a long time should be changed as little as possible"; or comparing it with the theory of the indigenous peoples' rights. However the tribunal did not explicitly refer to any of these, Ibid at 308-309, 316.
} 
the community of fishermen". ${ }^{477}$ While the absence of a clear basis in international law for the tribunal's decision in this regard has been criticized, ${ }^{478}$ such criticism is arguably misplaced. While the parties did not explicitly authorize the tribunal to decide based on equity, the authority of the tribunal to incorporate equity, fairness, and other relevant considerations into its decision making should be viewed as inherent in the two-dimensional nature of arbitration and integral to the role of an arbitral tribunal in an interstate territorial dispute. Moreover, the parties' acceptance and implementation of the awards rendered by the tribunal in this case arguably suggests that this aspect of the tribunal's decision was both required and legitimate.

Presumably having in mind the practical effects of its decision on the lives of the people of both states, and in order to facilitate its implementation, the tribunal rightly adopted a twodimensional view of the dispute, its own role, and the underlying interests of the parties, and did not consider itself bound by norms of traditional international law, such as the notion of state sovereignty. ${ }^{479}$ The inclusion of the detailed fishing regime in the Second Award and the tribunal's consideration of broader non-legal issues beyond the narrow territorial dispute submitted to it by the parties therefore evidences the arbitrators' recognition of the "diplomatic dimension" of arbitration and the inadequacy of strictly legal solutions to non-legal questions.

Further developing their role as "diplomats", in the Second Award the arbitrators also took into account relevant factors that extended beyond the immediate interests of the parties, including international navigation considerations, the international importance of the shipping lane in the disputed area, ${ }^{480}$ and the fact that there were potentially additional claims by other states in this area. These evidence the tribunal's consideration of its own responsibility to account for the practical effects of its decisions and to prevent any escalation in a "sensitive region" 481 where there may be multiple and overlapping territorial claims. Therefore, the tribunal considered the delimitation of the parties' maritime boundary not merely as a legal question, to be determined based on strict legal criteria, but as a broader regional issue, which required the application of diplomacy and extra-legal considerations. This approach of the tribunal arguably led to a more equitable and balanced outcome that was readily accepted by the parties.

\footnotetext{
477 Ibid at 310 .

478 Ibid.

${ }^{479}$ Ibid at 307-308.

${ }^{480}$ Red Sea Islands Second Award, supra note 394 at paras. 125, 128, 155, 162.

${ }^{481}$ Red Sea Islands compromise, supra note 379, Preamble.
} 
In summary, the flexible approach adopted by the arbitrators, their liberal interpretation of the Arbitration Agreement, and their incorporation of equitable considerations as part of the international law and other relevant non-legal considerations where appropriate, all arguably contributed to the successful resolution of the parties' dispute and evidence the arbitrator's twodimensional understanding of the arbitral process and their dual role as "diplomats" and "judges" within this process. This approach enabled the arbitral tribunal to formulate a compromise taking into account the parties' underlying interests and the broader implications of its own decisions, which arguably legitimized the tribunal's adoption of a broad and flexible interpretation of the Arbitration Agreement and the limits placed on its authority by the parties.

\subsection{Conclusion}

The Red Sea Islands arbitration has been considered as one of the most significant international arbitrations of the end of the twentieth century, ${ }^{482}$ successfully resolving a dispute in one of the most strategically sensitive regions of the world. ${ }^{483}$

There were critically important issues associated with the disputed legal questions of sovereignty and maritime boundaries submitted to the arbitral tribunal in this case. These included the historical and economic fishing rights of the two peoples and the impact of possible regional instability on international navigation. The tribunal's "intention of reconciling in a fair manner the opposite political and legal interests of Eritrea and Yemen [wa]s patent", ${ }^{484}$ and its goal was undoubtedly to balance "all the considerations invoked by the parties", demonstrating how "social reality and the perimeter of law could simultaneously form the foundation of a territorial decision". 485

The social reality considered by the tribunal in the present case had to reflect not only the ancillary rights of the parties that would inevitably be affected by the its decision on territorial sovereignty, but also the fact that this case involved a newly-independent state, Eritrea, and its potential reaction to "international law of a pro-European and pro-Western origin". ${ }^{486}$ The tribunal's decision accounted for both of these interrelated legal and extra-legal aspects by

\footnotetext{
${ }^{482}$ Queneudec, supra note 165 at 1.

${ }^{483}$ Kwiatkowska, "The Eritrea-Yemen Arbitration", supra note 378 at 1.

${ }^{484}$ Emphasis added. Antunes, "Maritime Delimitation", supra note 393 at 341.

${ }^{485}$ Antunes, "First Stage", supra note 378 at 382-383.

${ }^{486}$ Ibid at 385.
} 
providing specific instructions for the protection of the fishing rights of the Eritrean people, and thereby "bridging the gap between different regional legal traditions and contemporary international law". 487

This arbitration has been viewed as "remarkable" because the tribunal "endeavored to fulfill a pedagogical role towards the two States while taking great care to scrupulously analyze the arguments put forward by each and to readily reveal the grounds which it deemed it had to retain or, on the contrary, reject them". ${ }^{488}$ Therefore, although the tribunal adopted a strong "diplomatic" approach to its own role, this did not prevent it from rendering two awards that were also well-reasoned and founded in law to some extent, and that were unequivocally implemented by the parties.

While some aspects of the tribunal's decisions, particularly with respect to the application of Islamic law and the enforcement of a "traditional fishing regime" of its own creation are unusual and may be controversial, it is precisely such "arbitral activism" that is arguably called for in interstate territorial arbitrations involving political, cultural, historical, or other extra-legal issues. As some of the other arbitrations reviewed in this paper demonstrate, confining such issues to strict "legal" resolution is unlikely to succeed, and arbitral tribunals should therefore be authorized to apply, or apply sua sponte, legal principles flexibly as well as extra-legal principles as required for rendering a fair and effective decision.

In summary, this case arguably illustrates the advantages of interstate arbitration as a twodimensional dispute resolution mechanism, and its potential to successfully resolve interstate territorial disputes where the parties' and arbitral tribunal's perception of the purpose of arbitration "is not only to 'state the law' and to settle the dispute...by strict application of the legal rules...[but] also to ease the tensions and encourage the re-building and development of lasting co-operation between the two disputing States". ${ }^{489}$ This case therefore reflects the true "role of arbitration in the peaceful resolution of disputes and the maintenance of peaceful relations between states", ${ }^{490}$ and demonstrates the arbitrators' ability to effectively resolve legal

\footnotetext{
${ }^{487}$ Ibid.

${ }^{488}$ Queneudec, supra note 165 at 16.

${ }^{489}$ Ibid at 5-6.

${ }^{490}$ Johnson, "Eritrea-Yemen”, supra note 374 at 446.
} 
as well as political, strategic, or other questions by exercising both legal and diplomatic judgment. $^{491}$

\section{The Eritrea-Ethiopia Boundary Commission, 2002}

\subsection{Background}

Following Eritrea's secession from Ethiopia in 1993, a series of economic and political disagreements and border clashes between the neighbouring states in the second half of the 1990s culminated in a full-scale war lasting from May 1998 to June $2000 .^{492}$ The war erupted in an Ethiopian-held border village seized by Eritrea, Badme, an essentially barren piece of land devoid of any resources. ${ }^{493}$ Unlike the common intrastate conflicts in Africa during the post-Cold War era, the Ethiopia-Eritrea war displayed the hallmarks of a conventional interstate border confrontation. ${ }^{494}$ Ethiopia eventually gained the upper hand militarily and advanced deep into

\footnotetext{
${ }^{491}$ The arbitral tribunal's approach in this case facilitated a fair compromise despite the presence of circumstances external to the arbitration suggesting that a successful outcome would be difficult to obtain. Both parties reportedly felt "confident that their respective claims to the islands will be recognized by the tribunal", the actions of the relatively inexperienced Eritrean government were difficult to anticipate since it was "infused with nationalism" and "in the habit of resorting to arms without hemming and hawing", and Yemen was resisting domestic pressure to reclaim its national honor. Nevertheless, neither party could afford the financial toll of an arms race to defend their right. This case therefore evidences the utility of arbitration where the parties are entrenched in opposing positions and find it politically advantageous to leave the resolution of the dispute in the hands of a neutral third party, thereby avoiding being seen as weak or conciliatory by their domestic constituencies. Lefebvre, supra note 374 at 371, 376, 380, 384-385.

${ }^{492}$ Bahru Zewde, "The Historical Background of the 1998-2000 War: Some Salient Points" in Andrea de Guttry, Harry H.G. Post \& Gabriella Venturini, eds, The 1998-2000 War between Eritrea and Ethiopia (The Hague: T.M.C. Asser Press, 2009) at 22 [Zewde]; Jibril, supra note 42 at 640; Merrills, "Reflections", supra note 378 at 117; Schweigman, supra note 6 at 149.

${ }^{493}$ Dominique Jacquin-Berdal, "Introduction-The Eritrea-Ethiopian War" in Dominique Jacquin-Berdal\& Martin Plaut, eds, Unfinished Business: Ethiopia and Eritrea at War (The Red Sea Press, Inc., 2005) at xiii [JacquinBerdal]; Patrick Gilkes, "Violence and Identity along the Eritrean-Ethiopian Border" in Dominique Jacquin-Berdal \& Martin Plaut, eds, Unfinished Business: Ethiopia and Eritrea at War (The Red Sea Press, Inc., 2005) at 229 [Gilkes].

${ }^{494}$ The Ethiopia-Eritrea war was viewed as "the world's largest and deadliest" interstate conflict of its time, claiming 50,000-75,000 lives and displacing over 100,000 people from both states. Jacquin-Berdal, Ibid at ix; Fausto Pocar, "Introductory Remarks" in Andrea de Guttry, Harry H.G. Post \& Gabriella Venturini, eds, The 1998-2000 War between Eritrea and Ethiopia (The Hague: T.M.C. Asser Press, 2009) at xiii [Pocar]; Martin Plaut, "Background to War - From Friends to Foes" in Dominique Jacquin-Berdal \& Martin Plaut, eds, Unfinished Business: Ethiopia and Eritrea at War (The Red Sea Press, Inc., 2005) at 2 [Plaut, "Background"]; Getahun Seifu, "Ethiopian-Eritrean Conflict: Options for African Union Intervention" in "Managing Peace and Security in Africa: Essays on Approaches to interventions in African Conflicts" (December, 2012), The African Peace and Security Programme, Institute For peace and Security Studies, Addis Ababa University, at 148 [Seifu].
} 
Eritrean territory until a cease-fire was concluded in June 2000 and the Algiers Peace agreement was signed in December 2000 to regulate the postwar relationship between the parties. ${ }^{495}$

The main issue in dispute between the parties was the location of their mutual border, ${ }^{496}$ which was first delimited in three treaties concluded in 1900, 1902, and 1908 between Italy, the colonial power that ruled Eritrea at the time, and Ethiopia. This delimitation, however, was only partial, and the boundary was left un-demarcated on the ground. ${ }^{497}$ Eritrea became part of Ethiopia in 1952, at which point Ethiopia unilaterally declared the boundary treaties void. ${ }^{498}$ After Eritrea's independence, the dispute over the location of its common border with Ethiopia became inexorably linked to the parties' respective territorial control and integrity in a region where "geography determines politics" and colonial legacy divides peoples and territories along the common border. ${ }^{499}$ For Eritrea, a new state, the process of defining its boundaries was an integral part of asserting its sovereignty both domestically and internationally. For Ethiopia, an established state whose geostrategic position and access to the sea were already compromised by Eritrea's independence, any additional territorial concession would be interpreted as a sign of weakness. 500

In addition to the location of their mutual boundary, the "question of nationality" was also prominent in the parties' dispute, with Ethiopian and Eritrean leaders boasting incompatible conceptions of nationhood and a tradition of suspicion and hostility despite their shared ethnic and linguistic origins. ${ }^{501}$ The parties' mutual boundary acquired a significant symbolic role in the formation of Eritrean nationalism and an Eritrean national identity that was antithetical to that of

\footnotetext{
${ }^{495}$ Plaut, "Background", Ibid at 1-2; Martin Plaut, "The Conflict and its Aftermath" in Dominique Jacquin-Berdal \& Martin Plaut, eds, Unfinished Business: Ethiopia and Eritrea at War (The Red Sea Press, Inc., 2005) at 107, 110 [Plaut, "Aftermath"].

${ }^{496}$ The border consisted of three sections - central, western, and eastern.

${ }^{497}$ Eritrea v Ethiopia (2002), Decision Regarding Delimitation of the Border Between the State of Eritrea and the Federal Democratic Republic of Ethiopia, 41:5 ILM 1057 at para. 2.7 [Eritrea-Ethiopia Decision]; Merrills, "Reflections", supra note 378 at 119; Zewde, supra note 492 at 22; Malcolm N. Shaw, "Title, Control, and Closure? The Experience of the Eritrea-Ethiopia Boundary Commission" (2007) 56 ICLQ 755 at 756 [Shaw, "Title, Control, and Closure"].

${ }^{498}$ McHugh, supra note 70 at 212-213; Shaw, "Title, Control, and Closure”, Ibid at 756.

${ }^{499}$ Gian Paolo Calchi Novati, "The Lines of Tension in the Horn and the Ethiopia-Eritrea Case" in Andrea de Guttry, Harry H.G. Post \& Gabriella Venturini, eds, The 1998-2000 War between Eritrea and Ethiopia (The Hague: T.M.C. Asser Press, 2009) at 3 [Novati]; Federica Guazzini, "The Eritrean-Ethiopian Boundary Conflict: the Physical Border and the Human Border" in Andrea de Guttry, Harry H.G. Post \& Gabriella Venturini, eds, The 1998-2000 War between Eritrea and Ethiopia (The Hague: T.M.C. Asser Press, 2009) at 109 [Guazzini].

${ }_{500}^{500}$ Jacquin-Berdal, supra note 493 at xiv.

${ }^{501}$ Ibid at xiii; Plaut "Background", supra note 494 at 4; Novati, supra note 499 at 17.
} 
Ethiopia. ${ }^{502}$ Economic disagreements, for instance over Ethiopia's access to the sea, which further exposed the parties' dysfunctional relationship and imprecise mutual border, also underlined their motivation to escalate the conflict and remained fundamental to its resolution. ${ }^{503}$ Therefore, while the war was initially characterized as merely a "border dispute", it in fact concerned many complex underlying historic and nationalistic issues arising out of the parties' problematic relationship, and has even been labeled by Eritrea as its "second war of independence". 504

After the war and the signing of the Algiers Peace agreement, the village of Badme remained a symbol of the parties' sacrifice, national identity, and honour. While the war ended with a military victory for Ethiopia, a "war of words" continued to accompany a diplomatic battle over Badme and other disputed areas. ${ }^{505}$ The positions of the parties, moreover, remained essentially unchanged after the war, and they were both equally stubborn in refusing to make concessions. Ethiopia demanded Eritrea's unconditional withdrawal, asserting that Badme was part of its sovereign territory. Eritrea, for its part, sought a demilitarization of the area and arbitration, since it believed that the colonial boundary treaties located the village within its borders. ${ }^{506}$

\subsection{The arbitration agreement and procedure}

The 2000 Algiers Peace agreement (“Agreement”) provided for the cessation of hostilities, reaffirmed "the principle of respect for the borders existing at independence", 507 and established "a neutral Boundary Commission composed of five members shall be established with a mandate to delimit and demarcate the colonial treaty border based on pertinent colonial treaties (1900, 1902 and 1908) and applicable international law". ${ }^{508}$ Despite the unclear terminology used in the

\footnotetext{
502 Guazzini, supra note 499 at 130, 134.

${ }^{503}$ Jacquin-Berdal, supra note 493 at xiii-xiv; Plaut, "Background", supra note 494 at 17; Seifu, supra note 494 at $165-166$.

${ }^{504}$ Richard Reid, "'Ethiopians believe in God, Sha'abiya believe in mountains': the EPLF and the 1998-2000 war in historical perspective" in Dominique Jacquin-Berdal \& Martin Plaut, eds, Unfinished Business: Ethiopia and Eritrea at War (The Red Sea Press, Inc., 2005) at 25, 34 [Reid].

505 Guazzini, supra note 499 at 133.

${ }^{506}$ Plaut, "Aftermath", supra note 495 at 90, 110; Siphamandla Zondi \& Emmanuel Réjouis, "The Ethiopia-Eritrea Border Conflict and the Role of the International Community" (2006) 6(2) African Journal on Conflict Resolution 69 at 73 [Zondi \& Réjouis].

${ }^{507}$ Agreement Between the Government of the Federal Democratic Republic of Ethiopia and the Government of the State of Eritrea (Eritrea and Ethiopia), 12 December 200, Article 4(1) [Eritrea-Ethiopia compromis].

${ }^{508}$ Ibid at Article 4(2).
} 
Agreement for political purposes, the process that the parties had in mind was clearly arbitration. $^{509}$

The Agreement further provided that the Boundary Commission ("Commission") "shall not have the power to make decisions ex aequo et bono", 510 and that each party shall appoint two commissioners, "neither of whom shall be nationals or permanent residents of the party making the appointment", 511 and those commissioners shall select the president of the Commission, who also shall not be neither a national nor permanent resident of either party. ${ }^{512}$ Sir Elihu Lauterpacht (Britain) served as President of the Commission, Ethiopia appointed Sir Arthur Watts (Britain) and Prince Bola Adesumbo Ajibola (Nigeria), and Eritrea appointed Michael Reisman (U.S.A.) and former President of the ICJ, Stephen Schwebel (U.S.A.). The parties were to provide their claims and evidence to the Commission within 45 days, ${ }^{513}$ and the Commission was to endeavour to make its delimitation decision within six months. ${ }^{514}$

The Agreement also provided for the establishment of a second five-member neutral Claims Commission, ${ }^{515}$ in line with the parties' commitment to address "the negative socio-economic impact of the crisis on the civilian population, including the impact on those persons who have been deported". 516

${ }^{509}$ Kaiyan Homi Kaikobad, "The Eritrea-Ethiopia Boundary Commission: A Legal Analysis of the Boundary Delimitation Decision of 13th April 2002 and Relevant Subsequent Decisions" in Andrea de Guttry, Harry H.G. Post \& Gabriella Venturini, eds, The 1998-2000 War between Eritrea and Ethiopia (The Hague: T.M.C. Asser Press, 2009) at 175 [Kaikobad].

${ }^{510}$ Eritrea-Ethiopia compromis, supra note 511 at Article 4(2).

${ }^{511}$ Ibid at Article 4(4).

${ }_{512}^{51}$ Ibid at Article 4(5).

${ }^{513}$ Ibid at Article 4(8).

${ }^{514}$ Ibid at Article 4(12).

${ }^{515}$ While the work of the Claims Commission is important in illustrating the potentially broad use of arbitration in interstate dispute resolution, it did not directly address the territorial dispute between the parties and its related issues. A detailed analysis of its work is therefore beyond the scope of this paper.

${ }^{516}$ Eritrea-Ethiopia compromis, supra note 511 at Article 5(1). Claims were to be submitted to the Commission by the state parties on their own behalf, on behalf of their nationals, or on behalf of non-nationals, within one year. Similarly to the Boundary Commission, the Claims Commission was to apply relevant rules of international law and was not authorized to make decisions ex aequo et bono. Although the two Commissions were conceived as complementary, the mandate of the Boundary Commission was to resolve a specific territorial dispute, while the Claims Commission was set up to resolve a wide range of disputed issues and multiple claims emanating from the parties' armed conflict. These included claims regarding unlawful expulsion, displacement, and detention of civilians, unlawful treatment of prisoner of war, loss, damage, or injury claims, issues of diplomatic law, and issues regarding economic relations during the armed conflict. The Commission rendered a total of 17 partial and final awards concerning both liability and damages arising from the parties' claims, which have been regarded as a reaffirmation of "essential principles of international law outlined in the Geneva Conventions". Eritrea-Ethiopia compromis, supra note 507 at Article 5(8), (9), (13); Edoardo Greppi, "The 2000 Algiers Agreements", in Andrea de Guttry, Harry H.G. Post \& Gabriella Venturini, eds, The 1998-2000 War between Eritrea and Ethiopia (The 


\subsection{The parties' claims}

The arguments of both Eritrea and Ethiopia centered on the interpretation of the colonial treaties purporting to delimitate their common boundary and the accompanying maps, thereby largely focusing on the "legal dimension" of the arbitration. ${ }^{517}$ The parties differed, however, on the limits placed on the Commission's authority in carrying out this interpretative task. Eritrea contended that the 1900 treaty map provided sufficient guidance to enable the Commission to identify each of the disputed components of the boundary line. Eritrea therefore claimed that the treaty effectively delimited the boundary and led to a distinctive cartographic outline. ${ }^{518}$ Ethiopia, on the other hand, claimed that the boundary had not been delimited and that the task of the Commission was not to delimit it de novo based on the treaty. ${ }^{519}$

\subsection{The commission's decision making process}

The Commission made several findings that seemingly indicated its recognition of the “diplomatic dimension" of the arbitral process, ${ }^{520}$ however it ultimately did not incorporate this

Hague: T.M.C. Asser Press, 2009) at 61 [Greppi]; Merrills, "Reflections", supra note 378 at 127; Eritrea-Ethiopia Claims Commission, Rules of Procedure, Article 30; Andrea de Guttry, Harry H.G. Post \& Gabriella Venturini, eds, The 1998-2000 War between Eritrea and Ethiopia (The Hague: T.M.C. Asser Press, 2009), Preface at vi; Brooks W. Daly, "Permanent Court of Arbitration" in Chiara Giorgetti, ed. The Rules, Practice, and Jurisprudence of International Courts and Tribunals (Leiden: Martinus Nijhoff Publishers, 2012) at 55-57 [Daly].

${ }^{517}$ In the central section of the boundary, Article 1 of the 1900 treaty provided that the boundary ran along "the line from the Mareb-Belesa-Muna, traced on the map annexed", and the parties differed on the actual identity of these named rivers. In the western section of the boundary, which included the contentious village of Badme, Ethiopia claimed a straight line going north-east, while Eritrea claimed a ' $v$ ' shape line that dipped south-east and then moved north-east in a straight line. Article 1 of the 1902 treaty provided that the boundary was to follow the course of the river Maiteb "so as to leave Mount Ala Tacura to Eritrea, and join the Mareb at its junction with the Mai Ambessa", and so that "the Canama tribe belong to Eritrea". The dispute in this section of the border therefore concerned the identity and course of the river "Maiteb" with regard to which contemporary maps differed, and the question of the location of the Canama tribe. The treaty was written in three different languages - Amharic, English, and Italian which resulted in translation problems, and it did not contain a map. Therefore, the relevant rivers were described by different names in the three versions of the treaty, and the parties disagreed as to which of two possible rivers the treaty was in fact referring to. In the eastern section of the boundary, Article 1 of the 1908 treaty provided that from the "frontier of the French possessions of Somalia...the boundary continues south-east, parallel to and at a distance of 60 kilometres from the coast". Shaw, "Title, Control, and Closure", supra note 497 at 764, 768-769, 771; EritreaEthiopia Decision, supra note 497 at paras. 5.3, 5.14-5.15, 6.2; Abebe Zegeye \& Melakou Tegegn, "The Post-war Border Dispute between Ethiopia and Eritrea: On the Brink of Another War?" (2008) 24(2) Journal of Developing Societies, 245 at 262-263 [Zegeye \& Tegegn]; McHugh, supra note 70 at 214; Kaikobad, supra note 509 at 179 , 186.

${ }^{518}$ Eritrea-Ethiopia Decision, supra note 497 at para. 2.27.

${ }^{519}$ Ethiopia also claimed that a comparison should be made between the map annexed to the treaty and a modern map based on satellite imaging, since the former did not accurately represent the relevant geography, particularly with respect to the depiction of the named rivers. Eritrea-Ethiopia Decision, Ibid at paras. 2.29-2.30.

${ }^{520}$ For instance, the Commission decided that the reference in the Agreement to "applicable international law" entitled it to go beyond the law of treaty interpretation and to take into consideration customary international law, even if it may alter the colonial treaties. Eritrea-Ethiopia Decision, Ibid at paras. 3.14-3.15; Merrills, "Reflections", 
dimension in its decision making, and instead adopted a one-dimensional and legalistic approach to the resolution of the parties' dispute.

The Commission adopted a literal and restrictive interpretation of the Agreement, finding as a preliminary matter that the relevant date for determining the parties' border was the date of Eritrea's independence in 1993, and that no subsequent developments are to be taken into account unless they are "a continuance or confirmation of a line of conduct already clearly established, or take the form of express agreements between" the parties. ${ }^{521}$ Therefore, all elements of effective Ethiopian administration in certain sections of the boundary became irrelevant. ${ }^{522}$ The Commission also strictly followed the principle of contemporaneity, ${ }^{523}$ which involved giving expressions used in the treaties the meaning that they would have possessed at that time. 524

Moreover, while the Commission found that the description contained in the 1900 treaty "fell short of a desirably detailed description, particularly in the light of the uncertain knowledge at the time concerning the topography of the area and the names to be given to geographical features", 525 it nonetheless considered the map annexed to the treaty to be of "critical importance". ${ }^{526}$ The Commission decided the location of the named rivers based on this map, noting that it should be followed "so long as it is not shown to be so at variance with modem knowledge as to render it valueless as an indicator of what the Parties could have intended on the ground", but that it was important not to attribute "far-reaching consequences to relatively minor discrepancies". ${ }^{527}$ Furthermore, the Commission took note of the parties' subsequent conduct and

supra note 378 at 119,122 . Nonetheless, the Commission proceeded to rely on the "pertinent colonial treaties" for much of its Decision, Jon Abbink, "Law Against Reality? Contextualizing the Ethiopian-Eritrean Border Problem" in Andrea de Guttry, Harry H.G. Post \& Gabriella Venturini, eds, The 1998-2000 War between Eritrea and Ethiopia (The Hague: T.M.C. Asser Press, 2009) at 146 [Abbink].

${ }^{521}$ Eritrea-Ethiopia Decision, supra note 497 at para. 3.36; Greppi, supra note 516 at 63.

${ }^{522}$ Greppi, Ibid at 64-65.

${ }^{523}$ According to which "a treaty should be interpreted by reference to the circumstances prevailing when the treaty was concluded", Shaw, "Title, Control, and Closure", supra note 497 at 762.

${ }^{524}$ Eritrea-Ethiopia Decision, supra note 497 at para. 3.5.

${ }^{525}$ Ibid at para. 4.8.

${ }^{526}$ Shaw, "Title, Control, and Closure", supra note 497 at 768.

${ }^{527}$ Eritrea-Ethiopia Decision, supra note 497 at para. 4.36. 
activities, ${ }^{528}$ however it found this evidence to have no legal effect on the delimitation of the boundary other than in several specific areas. ${ }^{529}$

Although the Commission purported to analyze the 1902 treaty in light of its object and purpose, it found that this included the assignment of the Cunama tribe, who inhibited the village of Badme, to Eritrea, ${ }^{530}$ even though the village was continuously under the de facto control of Ethiopia. ${ }^{531}$ The Commission also considered evidence of Ethiopia's collection of taxes, establishment of an elementary school, and the destruction of incense trees in the area, but nonetheless rejected Ethiopia's claim to effective title, finding that this evidence "was not sufficiently clear in location, substantial in scope or extensive in time to displace the title of Eritrea". 532

Finally, the Commission found that the 1908 treaty provided for a "geometric method of delimitation", which it interpreted to mean that "prior effectivités...are not to play a role in the calculation as to where the boundary is located". ${ }^{533}$ While the Commission found that this method did not mean, as Eritrea argued, that all the Commission had to do was to apply the treaty delimitation to a map of the area, but rather that what was provided was "a formula, the application of which required a series of subsidiary decisions on other critical matters", ${ }^{534}$ it nonetheless proceeded to find that "departures from the geometric method in the demarcation process would only be permissible to take account of the nature and variation of the terrain". 535

\footnotetext{
${ }^{528}$ Ibid at para. 4.60 et seq, Appendix A, "Subsequent Conduct of the Parties in the Sector Covered by the 1900 Treaty". The Commission has been criticised for not including the evidence of subsequent conduct in the body of the award, Kaikobad, supra note 509 at 178-179.

${ }^{529}$ Two such areas were awarded to Eritrea on the basis of an admission made by Ethiopia during the proceedings and Eritrean activity, and another two areas were awarded to Ethiopia on the basis of the parties' conduct. EritreaEthiopia Decision, supra note 497 at paras. 4.62, 4.71, 4.75, 4.78; Kaikobad, supra note 509 at 178; Merrills, "PCA", supra note 54 at 5.

${ }^{530}$ Eritrea-Ethiopia Decision, Ibid at paras. 5.29, 5.90, Appendix B, "The Location of the Cunama"; Merrills, "Reflections", supra note 378 at 119-120; Plaut, "Aftermath", supra note 495 at 112; McHugh, supra note 70 at 215. The Commission has also been criticised for not including the discussion of the Cunama nation in the body of the award, Kaikobad, supra note 509 at 180.

${ }_{533}^{531}$ Eritrea-Ethiopia Decision, supra note 497 at paras. 5.44-5.96.

${ }^{532}$ Ibid at paras. 5.92-5.95; Merrills, "Reflections", supra note 378 at 120; Plaut, "Aftermath", supra note 495 at 112.

${ }^{533}$ Eritrea-Ethiopia Decision, supra note 497 at para. 6.5.

${ }_{534}^{534} \mathrm{Ibid}$ at para. 6.14.

${ }^{535}$ With regard to the application of the geometric method, the Commission decided that this was a question of both delimitation and demarcation, and that the line of delimitation would "serve as the basis for the demarcation". The Commission decided to use satellite images to produce this boundary, which it then reviewed in light of the parties' subsequent conduct and common agreement. Ibid at paras. 6.14, 6.17, 6.20-6.32, 6.34; Shaw, "Title, Control, and Closure", supra note 497 at 771, 782; Kaikobad, supra note 509 at 186-187; Merrills, "Reflections", supra note 378 at 120 .
} 


\subsection{The outcome of the arbitration}

The Commission delivered a unanimous delimitation decision in April 2002. While the Commission concluded in its delimitation decision that the western section of the boundary belonged to Eritrea, it did not indicate the exact location of the contentious village of Badme on the accompanying maps, providing instead only the co-ordinates of the line along which the border would run.

Shortly thereafter, Ethiopia submitted a "Request for Interpretation, Correction and Consultation", mostly concerning the relation between the Commission's delimitation decision and the second phase of demarcation. This request was in fact "an open objection and challenge" to the decision, ${ }^{536}$ and was rejected by the Commission on the ground that it sought the reopening of matters clearly settled by the decision, and therefore went beyond the Commission's powers of interpretation or revision and was inadmissible. ${ }^{537}$ Eritrea ultimately accepted the Commission's delimitation decision, even though it continued to dispute several areas it had lost, in order not to jeopardize the decision regarding Badme, ${ }^{538}$ however widespread opposition to the decision persisted within Ethiopia, preventing the government from accepting the decision. ${ }^{539}$

Ethiopia argued that the demarcation of the boundary should be adapted to account for "human and physical geography", or else it would result in an impractical boundary that divided communities. ${ }^{540}$ The Commission claimed, however, that since it was not authorized to decide $e x$ aequo et bono it could not take into account physical divisions of communities that may adversely affect the interests of the local inhabitants. ${ }^{541}$ Ethiopia proceeded to request the UN Security Council to set up an alternative mechanism to demarcate the boundary, claiming that the Commission was in "terminal crisis", however the Commission rejected the accusation that any

\footnotetext{
${ }^{536}$ Michael K. Addo, "The Role of Intergovernmental Agencies in the Management of Human Rights Risk" in Andrea de Guttry, Harry H.G. Post \& Gabriella Venturini, eds, The 1998-2000 War between Eritrea and Ethiopia (The Hague: T.M.C. Asser Press, 2009) at 458 [Addo].

${ }_{537}^{53}$ Merrills, "Reflections", supra note 378 at 118, 120; Kaikobad, supra note 509 at 213-214.

${ }^{538}$ Gilkes, supra note 493 at 229.

539 Jacquin-Berdal, supra note 493 at xix.

${ }^{540}$ Seifu, supra note 494 at 168-169.

${ }^{541}$ Guazzini, supra note 499 at 138.
} 
“crisis" existed that could not be cured by Ethiopia's compliance with its decision. ${ }^{542}$ In 2004 , Ethiopia stated that it was willing to accept the delimitation decision in principle if adjustments were made in the demarcation phase by way of negotiations between the parties, however Eritrea refused, demanding unconditional demarcation in accordance with the lines set out in the Commission's delimitation decision. ${ }^{543}$

The Commission attempted to commence its task of demarcating the boundary, however its work was obstructed by both Ethiopia, which refused to allow the necessary preparatory work to be carried out in the territory subject to its control in the western and central sections of the border, and Eritrea, which refused to allow the Commission to proceed in the eastern section, claiming that the demarcation activity was to be carried out simultaneously in all sections of the border. ${ }^{544}$ The Commission therefore proceeded to demarcate the boundary "virtually" by using image processing techniques, a process which was completed in 2006. Since the parties continued to refuse to cooperate with the Commission in the demarcation process on the ground, it declared this "virtual" demarcation to be final and its mandate to be completed, and ended its activity in 2007.545

The impact of the Commission's unilateral demarcation decision continues to be uncertain, ${ }^{546}$ as the border remains unmarked and sealed ${ }^{547}$ and Ethiopia retains control of areas allocated to Eritrea in the delimitation decision, including the village of Badme. ${ }^{548}$ Both parties also refuse to compromise, Eritrea asserting that the Commission's delimitation decision is final and backed by international law, while Ethiopia remains unmotivated to alter the status quo in light of its control over Badme and the lack of significant international pressure. ${ }^{549}$ The two countries therefore continue to live "in an impasse of 'no-war', 'no-peace", and low intensity conflicts have been witnessed recently along the common boundary. ${ }^{550}$

\footnotetext{
${ }^{542}$ Plaut, "Aftermath", supra note 495 at 115; Martin Pratt, "A Terminal Crisis? Examining the Breakdown of the Eritrea-Ethiopia Boundary Dispute Resolution Process" (2006) 23 Conflict Management and Peace Science 329 at 331 [Pratt].

${ }^{543}$ Abbink, supra note 520 at 157; Seifu, supra note 494 at 169; Jibril, supra note 42 at 667; Terrence Lyons, "The Ethiopia-Eritrea Conflict and the Search for Peace in the Horn of Africa" (2009) 120 Review of African Political Economy 167 at 169 [Lyons].

${ }^{544}$ Greppi, supra note 516 at 64-65; Shaw, "Title, Control, and Closure”, supra note 497 at 790.

${ }^{545}$ Merrills, "Reflections", supra note 378 at 118, 120-121; Daly, supra note 516 at 53.

${ }^{546}$ Daly, Ibid at 54.

${ }^{547}$ Plaut, "Aftermath", supra note 495 at 119.

${ }^{548}$ Lyons, supra note 543 at 167.

${ }^{549}$ Ibid at 167, 169-170.

${ }^{550}$ Seifu, supra note 494 at 146.
} 


\subsection{Analysis}

The ultimate failure of the Commission to resolve the parties' boundary dispute in this case is arguably rooted in its one-dimensional, narrow, and legalistic approach to its own role as well as to the parties' broader conflict. Indeed, its delimitation decision has been criticized for its "relentless effort to exclude anything that allows the application of initiative or discretion in line with the peculiarities and realities of creation and maintenance of Africa's large artificial borders". ${ }^{551}$ However, the Commission's approach to its task arguably resulted, at least in part, from the similarly one-dimensional and legalistic formulation of the issue to be determined by the parties and the limited scope jurisdiction granted to the Commission. Therefore, the "very seeds for the failure of the Commission's work were already laid in the formulation of the task given to the commission" by the parties. ${ }^{552}$

\subsubsection{The parties}

With respect to the composition of the Commission, it is arguable that a body charged with demarcation as well as delimitation should include at least one geographer in order for the process to be comprehensive and effective. The flexibility of the arbitration process and the freedom of the parties to appoint arbitrators of their choosing make the appointment of a nonjurist possible and, in some cases, desirable. While the parties in this case appointed the UN Cartographer as Secretary to the Commission and provided for the use of the technical expertise of the UN Cartographic Unit and other experts as the Commission deemed necessary, the primary role of the UN Cartographer and his unit appears to have been to provide cartographic support to the commission, which is different from having a geographer as a member of the Commission.

A geographer sitting on the Commission could have offered "a different perspective on the issues under discussion, provide map-interpretation skills during deliberations, and advise the legal experts on the many complex geographical aspects of the delimitation", thereby facilitating the "diplomatic" dimension of the arbitral process. ${ }^{553}$ Moreover, the presence of a geographer would likely have helped the other Commission members in the interpretation of geographic evidence

${ }^{551}$ Gbenga Odentun, "Africa before the International Courts: The Generational Gap in International Adjudication and Arbitration" (2004) 44(4) Indian Jrn Int Law 701-748, cited in The Carter Center, supra note 17 at 13 [Odentun].

${ }_{552}^{5}$ Ibid.

${ }^{553}$ Pratt, supra note 542 at 337. 
and might have prevented some of the technical errors in the delimitation decision, which were later on used by Ethiopia to challenge its validity. A geographer would have likely also insisted on a field survey of the disputed territory, and considering the poor quality of the mapping available to the Commission, "a geographer's insight into the landscape through which the boundary runs would have been invaluable in interpreting the three old boundary treaties". 554

In addition, the Commission was comprised of a majority of former ICJ judges, no nationals of the parties, and only one member from the African region. While the choice of a majority of ICJ judges may guarantee international law expertise and strengthen the "legal dimension of the arbitral process, it may also result in the adoption of an overly legalistic, one-dimensional, approach. Moreover, the parties' choice not to appoint their own nationals, or non-nationals familiar with the particulars of the dispute, may have compromised the Commission's ability to fully appreciate the parties' interests, their shared history, and the symbolic significance of their boundary and the contested village of Badme.

Furthermore, the parties presented the border dispute as the ultimate cause of the war and framed the question presented to the Commission narrowly, as concerning the location of their "colonial treaty border", where in fact the conflict extended far beyond a boundary dispute. This artificial focus on the technical border issue arguably contributed to the Commission's one-dimensional approach to the resolution of the dispute $;{ }^{55}$ left it unaware of the true complexity of the conflict; and it has been considered as the "utmost problem" with the arbitral process. ${ }^{556}$ The parties effectively masked a fundamentally political and historical conflict, "infused with a symbolism probably not found among other borders of the continent", ${ }^{557}$ as a legal one, thereby hindering the Commission's ability to render a practical and realistic decision.

Adding insult to injury, the parties presumed that "outdated and fallible" 558 colonial treaties, whose marks on the ground had substantially changed by the events and circumstances of the last century, would be sufficient to resolve their border dispute, and granted very narrow discretion to the Commission. While the parties' motivation in limiting the Commission's mandate was

\footnotetext{
554 Ibid.

${ }^{555}$ Guazzini, supra note 499 at 110.

${ }^{556}$ Seifu, supra note 494 at 171.

${ }^{557}$ Guazzini, supra note 499 at 121.

${ }^{558}$ Seifu, supra note 494 at 172.
} 
probably to protect their interests, it arguably led to an ultimately detrimental outcome. ${ }^{559}$ For instance, a broader mandate might have allowed for creative solutions to the problem of the village of Badme that would have been more acceptable to the parties if proposed as part of an overall boundary settlement package rather than following an unequivocal ruling on legal title based on colonial treaties. ${ }^{560}$ Granting broad authority to the arbitral tribunal is therefore arguably to be preferred over a narrow and legalistic arbitration agreement ${ }^{561}$ where disputed boundaries were established by colonial treaties, which often contain vague descriptions. To limit an arbitral tribunal's recourse to additional material beyond the interpretation of such treaties may be counterproductive and lead to either an unreasoned or unreasonable award. ${ }^{562}$

The parties' express exclusion of a decision ex aequo et bono also evidenced their onedimensional approach to the arbitration; arguably affected the Commission's perception of its own mandate; and may have signaled to it that the parties would not tolerate any decision not made purely on the basis of law. As already mentioned, excluding the power to decide ex aequo et bono is often the chosen course in interstate arbitrations concerning disputes with political implications, as in the present case, and may seem appropriate at first blush. ${ }^{563}$ However, it was precisely this exclusion of any consideration of what is fair and just that led to Ethiopia's perception of the delimitation decision as being "unjust" and to its request that the Commission reconsider its decision on the basis of fairness and justice. ${ }^{564}$ From the Ethiopia's perspective, it had won the war and its people were hoping that it would at least retrieve access to the ports it lost with Eritrea's independence and to "contested and symbolically significant" 565 places like Badme. It therefore seems rather counterintuitive that the Ethiopian government agreed to entrust such politically significant issues to an external commission that was to be guided by "colonial treaties of indeterminate status" ${ }^{\$ 56}$ and was not permitted to consider what was just and fair in the circumstances.

Furthermore, in order for an arbitration process to successfully resolve an interstate territorial dispute, the parties must be committed and view it as a suitable procedure in the circumstances.

\footnotetext{
${ }^{559}$ Pratt, supra note 542 at 334.

560 Ibid at 335.

${ }^{561}$ Merrills, "Reflections", supra note 378 at 122.

562 Ibid.

${ }^{563}$ Greppi, supra note 516 at 61-62.

564 Jibril, supra note 42 at 652-653.

565 Zewde, supra note 492 at 23.

${ }^{566}$ Ibid.
} 
In the present case, it seems that arbitration was, at least to some extent, imposed on the parties from outside, which may explain Ethiopia's hostility toward it. ${ }^{567}$ Ethiopia objected to arbitration throughout the process, from the conclusion of the Agreement and the selection of the arbitrators to the Commission's application of the Agreement, and although the parties generally agreed to submit their dispute to arbitration in 2000, it took six months of diplomatic pressure and mediation before Ethiopia agreed to actually proceed with the process. Ethiopia's reservations may have been related also to its significantly stronger position relative to that of Eritrea at the time the Agreement was concluded. Ethiopia had a substantially larger population, resources, and military might, and it made substantial territorial gains during the war. ${ }^{568}$ In any event, "the circumstances leading to the establishment of the Boundary Commission and its resulting lack of perceived legitimacy" likely made it more difficult for Ethiopia to accept the Commission's decision. $^{569}$

In summary, the parties arguably failed to appreciate the two-dimensional nature of the arbitral process. They did not give due consideration to the broader context of their conflict and the practical reality on the ground, and largely confined the Commission's authority to the interpretation of ambiguous colonial treaties whose status was controversial ${ }^{570}$ and which were declared "null and void" by Ethiopia in $1952 .{ }^{571}$ In addition, the parties, and particularly Ethiopia, were arguably not sufficiently invested in the arbitration process and were forced into it by external parties. In these circumstances, the legitimacy of the entire arbitration process was compromised from the start, and coupled with the Commission's one-dimensional and overly legalistic approach, inevitably resulted in a narrow delimitation decision limited in scope and impact. $^{572}$

\subsubsection{The Commission}

It may be argued that in light of the narrow mandate granted to it by the parties, the role of the Commission in the delimitation phase was "simply to clarify the alignment of an existing boundary, albeit one whose original definition was vague and frequently ambiguous". 573

\footnotetext{
${ }^{567}$ Pratt, supra note 542 at 334.

568 Jibril, supra note 42 at $663,665$.

${ }^{569}$ Pratt, supra note 542 at 334.

${ }^{570}$ Abbink, supra note 520 at 145; Guazzini, supra note 499 at 121.

${ }^{571}$ Greppi, supra note 516 at 61-62.

572 Abbink, supra note 520 at 152, 155.

${ }^{573}$ Pratt, supra note 542 at 334.
} 
According to this one-dimensional technical view, the Commission had no authority to adjust the boundary as depicted in the colonial treaties to take account of historical and geographical developments, regardless of how desirable this may have been. This position, however, seems "unreasonably inflexible" and should be rejected. ${ }^{574}$

Although the Commission was authorized to decide only in accordance with the three colonial treaties and international law principles, rather than ex aequo et bono, this arguably should not have prevented it from adopting a two-dimensional approach that would allow it to interpret such treaties and principles flexibly and take into account relevant extra-legal considerations such as the history of the parties' shared boundary, the symbolic significance of its location, the need for stability along the border, trade routes, social systems, and the rights of the affected communities. ${ }^{575}$ The parties' exclusion of an ex aequo et bono decision therefore should not have prevented the Commissioners from fully exercising their role as "judges" by conducting their own fact-finding, including ground survey, interviews, and review of local documents, rather than relying almost exclusively on archival material and secondary documents, ${ }^{576}$ and their role as "diplomats" by considering activities that had been taking place on the ground for decades, such as settlements, economic activities, customs ports, and court proceedings. ${ }^{577}$ The Commission's decision might have fared better with the parties, and particularly Ethiopia, had it taken into account such significant non-legal factors, and its failure to do so arguably led to a decision that "has not necessarily provided the basis for a lasting settlement". 578

The Commission's one-dimensional and legalistic approach to its own role and to the parties' dispute was also illustrated by its over-reliance on the colonial treaties, even though "decades of historical events" have since passed. ${ }^{579}$ In addition to being "partly fictitious and outdated" and lacking "clarity and status", ${ }^{580}$ these treaties were of minimal assistance in determining the border since they failed to provide any agreed upon point of departure or supporting details. The

\footnotetext{
${ }^{574}$ Ibid at 334-335. 7.3; Merrills, "PCA", supra note 54 at 8.

${ }^{576}$ Abbink, supra note 520 at 151-152, 155.

577 Ibid at 153.

${ }^{578}$ Jacquin-Berdal, supra note 493 at xiv, xix.

${ }^{579}$ Greppi, supra note 516 at 62.

${ }^{580}$ Abbink, supra note 520 at 146, 148.
}

575 The Commission was clearly aware of the customary rights of the local population, since with respect to a river boundary line that was left to be determined at the demarcation stage, it noted that "regard should be paid to the customary rights of the local people to have access to the river". Nonetheless, it largely failed to take these rights into account in its determination of the parties' mutual border, Eritrea-Ethiopia Decision, supra note 497 at para. 
cartographic depictions of rivers in the map annexed to the 1900 treaty did not conform to reality on the ground and presented many discrepancies as a result of lack of knowledge of the geographical features. ${ }^{581}$ The Commission's use of this map evidence also further disregarded the importance of state activity on the ground, and maps which did not accurately represent legally relevant activity on the ground should arguably have been awarded little probative weight. $^{582}$

Had the Commissioner properly executed their role as "judges", they arguably would have recognized the colonial treaties as artificial and merely indicative of the ever-changing power balance between the relevant regimes, ${ }^{583}$ and conducted a proper assessment of the colonial legacy of the border issue and its significance to the parties in terms of national identities and prestige politics. ${ }^{584}$ This would have been permissible had the Commission interpreted the parties' use of the term "delimit" in the Agreement as indicating that they did not intend to confine the Commission to mere interpretation of the treaties. ${ }^{585}$ This broader interpretation of the Agreement would have been the proper one and, had it been adopted by the Commission, may have resulted in a more flexible and less strict application of the colonial treaties. Instead, the Commission produced an impractical decision that contributed nothing to the resolution of the parties' territorial dispute ${ }^{586}$ and offered "little possibility of any solutions to the problems posed by the border". 587

A proper exercise of their role as "judges" would have led the Commissioners to broadly interpret the authority granted to them by the parties to consider "applicable international law" and to include various relevant legal principles, such as uti possidetis, effectivités, and equitable rules of international law, rather than focusing solely on the strict interpretation of the colonial treaties. ${ }^{588}$ The importance of the uti possidetis principle in determining the location of the parties' boundary was emphasised early on in the parties' reaffirmation of the "principle of

${ }^{581}$ Guazzini, supra note 499 at 121 . The Commission also arguably misapplied the available maps and relied on unilateral Italian-drawn maps claiming Eritrean territory, which was misunderstood by the Commission as having been accepted by Ethiopia, rather than on an Italian map showing the extent of Italy's claims and effective occupation in the early twentieth century, which did not extend to the Badme area, Abbink, supra note 520 at 149150.

${ }^{582}$ Kaikobad, supra note 509 at 200-201.

${ }^{583}$ Abbink, supra note 520 at 141-148.

${ }^{584}$ Ibid at 145.

${ }^{585}$ Kaikobad, supra note 509 at 182.

586 Abbink, supra note 520 at 151-152, 155.

587 Gilkes, supra note 493 at 230.

${ }^{588}$ Abbink, supra note 520 at 149. 
respect for the borders existing at independence" in the Agreement and their instruction that the boundary "shall be determined on the basis of pertinent colonial treaties and applicable international law". ${ }^{59}$ The application of this principle may have proven difficult in this case since Eritrea was part of Ethiopia and not a colony in the legal sense, but it should have at least been considered by the Commission, especially in light of its possible effect on Ethiopia's access to the sea. ${ }^{590}$

The Commissioners' legalistic approach to their role as "judges" was also evident in their reliance on evidence of subsequent conduct and administrative activity. The Commissioners essentially used this evidence to illuminate relevant provisions of the colonial treaties, rather than as a possible source of variation of the treaties. This is problematic since the probative value of relevant evidence should arguably be evaluated in light of the "facts and overall perspectives of the dispute" and independently of any treaty it is used to interpret. ${ }^{591}$ Instead, the Commission adopted a "textbook approach" to this evidence in its interpretation of the treaties, and failed to allow it to vary the boundary line to accommodate activities carried out on the ground that were inconsistent with their terms. 592

Another relevant consideration that the Commissioners failed to take into account as "judges" was the self-determination of peoples in the border area. ${ }^{593}$ The Commission has been criticized for the potential impact of its decision on the ethnic minorities living between Eritrea and Ethiopia, arguably exposing them to "the danger of disintegration and possible ethnic cleansing". 594 The right of minorities to recognition of their identity and to choose their nationality has already been recognized in international law, and, at the very least, provided an alternative avenue for the Commission to decide the location of the border while paying regard to human conditions on the ground.

\footnotetext{
${ }^{589}$ Eritrea-Ethiopia compromis, supra note 507 at Article 4(1); Merrills, "Reflections", supra note 378 at 117.

${ }^{590}$ Abbink, supra note 520 at 153-154.

${ }^{591}$ Kaikobad, supra note 509 at 194.

${ }^{592}$ Although the Commission recognized that Ethiopia presented stronger evidence of administrative activity and that this may justify modifying the 1900 treaty boundary, it ultimately decided that a modification of the treaty was uncalled for. Kaikobad, supra note 509 at 193-194, 209-211. In addition, Eritrea was arguably unable to provide any evidence of its administrative presence in the area of Badme, and prior to 1998 never raised claims to it. In order to establish ownership over it, moreover, there was a need for "international display of power and authority", which Ethiopia, rather than Eritrea established in this case. However, the Commission ignored the evidence provided by Ethiopia and reverted to the colonial treaties and maps, arguably neglecting the "applicable international law". Abbink, supra note 520 at 150-151, 154.

${ }^{593}$ Abbink, Ibid at 153-154.

${ }^{594}$ Gilkes, supra note 493 at 249.
} 
Instead, the Commission's decision not only failed to resolve existing disputed issues, but also reinforced one of the main problems associated with the parties' mutual border, namely the thousands of displaced people unable to return to their lands, and almost guaranteed that the border would remain unstable. ${ }^{595}$ Whether intentionally or not, the Commission effectively supported Eritrea's aim to divide these populations as a means of defining its national identity, "emphasizing national political claims at the expense of existing local cultural cross-border or trans-national links". 596 The result has been the rise of a host of new problems along the border, with no alternatives offered by the Commission for their resolution. ${ }^{597}$

In addition to inadequately carrying out their role as "judges", the Commissioners failed to exercise their role as "diplomats" all together. In addition to ignoring crucial extra-legal factors, they also did not consider the differences between the Common Law tradition to which they adhered and state practice and social norms in the Horn of Africa. While the Commissioners depended heavily on information provided by the parties and assumed that all relevant information will become available in this manner, Ethiopia and Eritrea rather undertook to restrict the supply of information and promote secrecy, and they could therefore not be relied upon to provide the full background material needed for an external adjudicator to reach a balanced decision. Despite this fundamental difference in legal custom, the Commission adopted a "self-denying ordinance" by which it refused to obtain independent access to information, leading it to render an impractical and unjust award.

The Commission's approach also led to confusion and misinterpretation of its award by the parties. Ethiopia's initial interpretation of the decision was that it retained sovereignty over the contentious village of Badme while the rest of the western section of the border was awarded to Eritrea, which it viewed as a "win-win situation". ${ }^{598}$ It later became clear, however, that Ethiopia's interpretation of the decision was inaccurate, and that Badme was in fact awarded to Eritrea. ${ }^{599}$ While the Commission may have believed that its decision was sufficiently clear and

\footnotetext{
595 Ibid at 230 .

596 Ibid at 250.

597 Ibid at 249-250.

598 Plaut, "Aftermath", supra note 495 at 113.

${ }^{599}$ While the Commission concluded in its delimitation decision that the western section of the boundary, where Badme was located, belonged to Eritrea, it did not specifically indicate the location of the village on the accompanying maps, instead providing only the co-ordinates of the line along which the border would run. As the disputed sovereignty over this village ignited the conflict to begin with, and since whoever had legitimate title to it could claim that it was justified in going to war over it, the Commission's failure to pronounce the location of the
} 
that it was spearing Ethiopia from further humiliation, ${ }^{600}$ it effectively avoided dealing with the most contentious issue in dispute between the parties, even though "to anyone with the slightest familiarity with the origins and courses of the conflict Badme had...a critical symbolic significance". ${ }^{601}$ This "rather childish move" arguably compromised the authority and legitimacy of its decision and contributed to its rejection by Ethiopia. ${ }^{602}$

In summary, while the Commission's approach may be understandable in light of the relatively narrow framing of its authority in the Agreement, it cannot be justified when viewed from a twodimensional perspective of the arbitral process. Regardless of the limits placed on it by the parties, the Commission ought to have exercised its dual role and account for reality, justice, custom, and equity, rather than merely strict law. ${ }^{603}$ Although only one narrow aspect of the parties' conflict, namely the location of their mutual border, was submitted for resolution to the Commission, demarcating this border was a "necessary prerequisite" for progress on other issues $^{604}$ and represented a window of opportunity to normalize the parties' relationship. ${ }^{605}$ To achieve this, however, the Commission had to consider the broader context, origins, and history of the dispute, as well as the parties' interests, shared norms, and established practices. In failing to do so it merely raised the stakes so that both parties became locked in their positions in a "prestige psychological battle". ${ }^{606}$ The fact that the Commission also attempted to demarcate the

village "unleashed a controversy that has yet to be resolved". It seems that the Commission in fact had no idea of the importance of Badme to the parties, which had a "critical impact" on the reception of its decision. As the Ethiopian Prime Minister commented: "for us Badme is nothing, but the principle behind invading Badme is everything". Failing to take these sentiments into account, the Commission's decision, rather than signalling the beginning of a peace process between the parties, brought them closer to war. Christopher Clapham, "Indigenous Statehood and International Law in Ethiopia and Eritrea" in Andrea de Guttry, Harry H.G. Post \& Gabriella Venturini, eds, The 1998-2000 War between Eritrea and Ethiopia (The Hague: T.M.C. Asser Press, 2009) at 167 [Clapham]; Plaut, "Aftermath", supra note 495 at 112-113; Plaut, "Background", supra note 494 at 3; Jacquin-Berdal, supra note 493 at xix.

${ }^{600}$ Plaut, "Aftermath", Ibid at 112.

${ }^{601}$ Clapham, supra note 599 at 167.

${ }^{602}$ Zegeye \& Tegegn, supra note 517 at 260 . The decision of the Commission to terminate its mandate also seems somewhat extreme, as it could have instead suspended itself for an indefinite period of time, which would have allowed it to reclaim its mandate if and when appropriate. While this may have been intended to encourage Ethiopia to accept the Commission's decisions as final and implement them, it was arguably an insufficient incentive in light of the partial and unsatisfactory nature of these decisions, and resulted in the dispute continuing unresolved and the parties remaining with no alternative recourse for de-escalating the growing military tensions between them. Guazzini, supra note 499 at 139; Kaikobad, supra note 509 at 220-222.

${ }^{603}$ Abbink, supra note 520 at 142-143.

${ }^{604}$ Lyons, supra note 543 at 169.

${ }^{605}$ Greppi, supra note 516 at 62.

${ }^{606}$ Abbink, supra note 520 at 144. 
boundary based on a narrow and impractical delimitation decision, even if legally sound, further exacerbated the negative attitude of the parties and countered the reality on the ground. ${ }^{607}$

\subsection{Conclusion}

The failure of the Commission's delimitation decision to resolve the parties' boundary dispute, and the demarcation debacle that followed it, left the conflict between Eritrea and Ethiopia unresolved. $^{608}$ The parties' one-dimensional approach to the arbitration process both artificially isolated the border question from the broader context of their dispute, and failed to give this complex aspect of the dispute, which had "almost spiritual significance" to them, ${ }^{609}$ its due weight. The Commission's reasoning and decision, moreover, reflected a similarly onedimensional and legalistic analysis, and an approach that over-simplified the parties' conflict. ${ }^{610}$

The narrow framing of the Commission's mandate by the parties and the rigid interpretation of this mandate by the Commission also led to a decision that "sealed off the prospects for flexibility, amendment and compromise". ${ }^{111}$ In light of the significant symbolic value of Badme, its grant to Eritrea against the initial expectations of both parties guaranteed that a compromise solution to this issue would not be reached and that the threat of armed conflict would continue to loom large. "Due to local pressures and the promises during mobilisation for war, both sides became stuck on getting that territory or their national pride is lost. The sentiment in the populations of the parties makes the matter of handing over Badme to Eritrea or Eritrea agreeing to dialogue look like a 'political suicide' none of whom could justify", ${ }^{612}$

This arbitration therefore demonstrates the importance of considering "the various levels of tension" involved in a particular dispute in order to "fully appreciate the situation on the ground, its causes, and possibilities for resolution", as well as the importance of expertise beyond the "pure understanding and appreciation of international law norms" to the resolution of disputes of

\footnotetext{
607 Ibid at 151 .

${ }^{608}$ Ibid at 142 .

${ }^{609}$ Clapham, supra note 599 at 162.

${ }^{610}$ This approach was prevalent in the West at the time and dismissively characterized the dispute as "two bald men fighting over a comb". Uoldelul Chelati Dirar, "Rivalry, Antagonism and War in the Nation 7 State-building Process: The H Factor in the Relations Between Eritrea and Ethiopia" in Andrea de Guttry, Harry H.G. Post \& Gabriella Venturini, eds, The 1998-2000 War between Eritrea and Ethiopia (The Hague: T.M.C. Asser Press, 2009) at 26 [Dirar]; Clapham, supra note 599 at 161.

611 Abbink, supra note 520 at 158.

${ }^{612}$ Seifu, supra note 494 at 169-170.
} 
this kind. ${ }^{613}$ In the present case, the significance of the parties' mutual border extended beyond its legal conception to shape the parties' expectations and claims and to underline the tensions between them. Since the Commission failed to fully grasp and consider these tensions, it was unsuccessful in resolving the parties' conflict. ${ }^{614}$

The Commission's decision is similar in many respects to the arbitral award rendered in the Beagle Channel case, and the failure of these two arbitrations to resolve the respective disputes can arguably be traced back to similar origins. In the Beagle Channel arbitration, the tribunal perceived its task in a one-dimensional manner, as the determination of the boundary between Chile and Argentina and the allocation of three disputed islands governed by the rights granted to the parties in a boundary treaty from 1881. Accordingly, the arbitrators focused exclusively on the interpretation of the treaty, thereby restricting their role to that of "judges", and inflexible "judges" at that. ${ }^{615}$ A similarly narrow and one-dimensional perception was adopted in the present case by the Commission, confining itself to a large extent to the legalistic exercise of interpreting the three colonial treaties, rather than actually delimitating the boundary in accordance with the relevant situation on the ground. In both cases, this approach was arguably responsible, at least in part, for the failure of the arbitral process and the rejection of the outcome by the losing party.

Some have argued that, in light of its failure, arbitration was the wrong dispute resolution model to apply in this case ${ }^{616}$ and that "this dispute settlement procedure ought not to have been embarked upon in the first place". ${ }^{617}$ However, it may alternatively be argued that it was not arbitration itself so much as the parties' and the Commission's misperception and misapplication of the process that prevented the successful resolution of the conflict in this case. The dispute submitted to the Commission, while seemingly legal in nature, carried with it significant nonlegal implications, which were compounded by the parties' shared history and unstable relationship and which both the parties and the Commission failed to take into consideration. ${ }^{618}$ Had the parties and the Commission recognized that the disputed issue was far more complex than a simple boundary delimitation, and had they perceived the arbitral process as "more

\footnotetext{
${ }^{613}$ Pocar, supra note 494 at xvii-xviii.

614 Ibid

${ }^{615}$ Kaikobad, supra note 509 at 183.

${ }^{616}$ Zewde, supra note 492 at 24; Seifu, supra note 494 at 172.

${ }^{617}$ Kaikobad, supra note 509 at 223.

${ }^{618}$ Abbink, supra note 520 at 155.
} 
efficient than diplomatic instruments and more flexible than adjudication by a permanent court", ${ }^{619}$ a fair and practical decision would have ensued, compatible with realities on the ground and capable of effectively resolving the conflict.

${ }^{619}$ Greppi, supra note 516 at 60; Clapham, supra note 599 at 161 


\section{Chapter 3}

\section{Lessons from the Case Studies}

The case studies analyzed above arguably illustrate both the limited extent to which interstate arbitration's two-dimensional traditional nature has been recognized in the context of territorial disputes involving armed conflict, and the impact that such limited recognition may have on the ultimate outcome and the successful resolution of such disputes by arbitration. It may be argued that the majority of the cases examined reflect the one-dimensional "judicialized" contemporary perception of interstate arbitration, according to which it is merely a procedurally flexible form of judicial settlement rather than a truly hybrid alternative mechanism designed to resolve all aspects of states' disputes. With the exception of the Red Sea Islands arbitration, in all of the cases examined the state parties, arbitral tribunal, or both, arguably adopted such a onedimensional, narrow, legalistic, and restrictive approach to the arbitral process, which resulted in its ultimate failure.

The parties in the Beagle Channel arbitration, Eritrea-Ethiopia arbitration, and particularly the Taba arbitration, restricted the authority of the arbitral tribunal to decide their dispute on the basis of international law and treaty interpretation, and they all submitted a single factual or legal issue to be determined by arbitration, which represented only a narrow aspect of their broader conflict. It may be argued, therefore, that the parties in these cases perceived arbitration as a onedimensional legalistic dispute settlement procedure designed to resolve legal questions based on the strict application of legal principles. Similarly, the arbitral tribunals in the Beagle Channel arbitration and the Eritrea-Ethiopia arbitration, which were largely comprised of ICJ judges, also arguably perceived the arbitral process as an essentially judicial and legalistic procedure in which their own mandate was strictly defined by the parties' arbitration agreement and excluded any residual discretion or authority. The failure of these two arbitrations to resolve the dispute submitted to them may therefore have been rooted, at least in part, in this restrictive, onedimensional, and "judicialized" perception of arbitration adopted by the state parties and the arbitral tribunals.

In contrast, the ultimate success of the Red Sea Islands arbitration and the Taba arbitration can arguably be credited to the broader, two-dimensional, and flexible understanding of the 
arbitration procedure adopted by both the parties and the arbitral tribunal in the former case, and by the arbitral tribunal in the latter case. In the Red Sea Islands arbitration, the relatively broad language and scope of the parties' Arbitration Agreement, the diverse constitution of the arbitral tribunal, and the relatively broad authority granted to it, all arguably contributed to the arbitral tribunal's ability to effectively resolve the parties' dispute. Moreover, the tribunal's own twodimensional perception of its own role, its liberal interpretation of the Arbitration Agreement, and its incorporation of equitable and extra-legal considerations even though it was not explicitly authorized to do so by the parties, arguably led to a balanced and fair award that was implemented by both parties and successfully resolved their dispute.

Similarly, the arbitral tribunal's flexible and two-dimensional approach to the parties' dispute and to its own mandate in the Taba arbitration arguably enabled it to overcome the practically impossible situation created by the parties in their Arbitration Agreement and to produce a sensible decision that ultimately resolved the disputed issue submitted to it. Had the parties' approach to the arbitral process in this case not been quite so restrictive and crippling, and had they not placed such severe restrictions on the arbitral tribunal, it might have also been able to devise a compromise settlement that would have been easier for Israel to accept, rather than a zero-sum award. The fact that the arbitral award as rendered was ultimately implemented by both parties should be credited to the a-typical circumstances of this case and the arbitral tribunal's resourcefulness and creative approach.

It seems, therefore, that state parties' and arbitral tribunal's perception of the nature, function, and purpose of the arbitral process, and of their own respective roles in that process, may have an impact on its ultimate success or failure. While not discounting the significance of other elements external to the arbitration itself, these cases arguably suggest that where arbitration is not understood and employed by parties and arbitrators as the two-dimensional hybrid mechanism that it truly is, the process suffers and the arbitral award is likely to be unsatisfactory and potentially remain unimplemented.

\section{A preliminary framework for interstate arbitration}

The theoretical account of the traditional two-dimensional "true nature" of interstate arbitration set out thus far must also be translated into practical tools that states and arbitral tribunals can use when considering arbitration in the context of interstate disputes involving political interests 
and armed conflict or the threat of armed conflict. The following suggested "best practices" are recommendations based on this theoretical account and drawn from the case studies examined above, and are intended to facilitate the successful use of interstate arbitration as a twodimensional mechanism in complex interstate disputes. This proposed operational framework is not designed to "plug up all the openings and to foresee every loophole...[or] to enclose arbitration within a rigid framework" that "runs the risk of hindering its development" ${ }^{620}$ Rather, it is intended to further develop the use of interstate arbitration in the spirit with which it was originally conceived thousands of years ago and "without compromising its 'voluntary' character". 621

\subsection{State parties}

\subsubsection{Choose the right arbitrators}

The parties' power over the composition of the arbitral tribunal "refers as much to its composition viewed as a function of the nationality of its members as it is a matter of their technical qualifications in matters other than competence in the law". ${ }^{622}$ The parties, therefore, can choose an arbitral tribunal consisting of all national arbitrators, all non-national arbitrators, or both nationals and non-nationals, as well as legal and non-legal experts, depending on the circumstances of the case. There is some merit to the inclusion of national arbitrators, as completely "independent tribunals pose a danger to international cooperation because they can render decisions that conflict with the interests of state parties". ${ }^{623}$ Moreover, a tribunal that includes both judges and non-judges may be less "judicial", and therefore more likely to facilitate the two-dimensional function of interstate arbitration and not "restrict the importance of factors falling upon the borderline of legal and equitable considerations". ${ }^{624}$ Parties may also consider appointing only their nationals to the arbitral tribunal, which may contribute to an acceptable compromise and emphasize diplomacy over the application of law. ${ }^{625}$

\footnotetext{
${ }^{620}$ Charles de Visscher, "Reflections on the Present Prospects for International Adjudication" (1956) 50 AJIL 469470 cited in Pinto, "Structure, Process, Outcome", supra note 2 at 256.

${ }^{621}$ Pinto, "Structure, Process, Outcome", supra note 2 at 256.

${ }^{622}$ Rosenne, supra note 110 at 454.

${ }^{623}$ Posner, Eric A. \& John C. Yoo, "Judicial Independence in International Tribunals" (2005) 93(1) Cal L Rev 1 at 7 [Posner \& Yoo].

${ }^{624}$ Shaw, "Beagle Channel”, supra note 186 at 442.

${ }^{625}$ Brower, supra note 86 at $270-271$.
} 
On the other hand, while appointing national arbitrators may reassure state parties that their interests and claims will be accounted for, such arbitrators may view themselves in a representative capacity and therefore be reluctant to make concessions necessary to reach a compromise $^{626}$ or to go along with anything that may be contrary to the interests of their country, which may easily result in deadlock. ${ }^{627}$ This may also compromise the neutrality of the arbitral tribunal, which is important in the resolution of bi-lateral disputes, ${ }^{628}$ and result in dissenting opinions that may weaken the legitimacy and persuasive force of the arbitral award. In a threemember tribunal, moreover, the inclusion of two national arbitrators may result in the remaining non-national arbitrator effectively becoming the sole decision maker due to lack of consensus. Therefore, parties would arguably be well-advised to consider appointing neutral non-national arbitrators who have some familiarity with the conflict and the parties' relationship, history, culture, and legal tradition, or alternatively providing for a five-member tribunal, in which the majority of arbitrators are non-nationals.

Furthermore, from a two-dimensional perspective, state parties may wish to consider appointing at least one arbitrator who is not a lawyer and who has non-legal expertise in certain circumstances. The ability to do so, generally not available to parties in international litigation before a permanent court, has the advantage of supplementing the arbitral decision-making process with extra-legal knowledge and expertise that is often required in complex interstate disputes in order to produce a fair and factually correct decision that would be acceptable to the parties. Moreover, this option may be important in some cultures, where a third-party adjudicator is chosen largely based on his familiarity with the context of the dispute, insight into the parties' relationship, his personal authority, and the respect he is awarded in the society, rather than his independence, impartiality, or legal qualifications and expertise. ${ }^{629}$

Regardless of the individual arbitrators who are ultimately appointed, it is most important that state parties exercise the right to choose their own arbitrators and not leave this task entirely in the hands of a third party. ${ }^{630}$ They should also provide in the arbitration agreement specific procedures in the event that they fail to appoint their arbitrators.

\footnotetext{
${ }^{626}$ Ibid.

${ }^{627}$ Ralston, supra note 81 at 29

${ }^{628}$ Posner \& Yoo, supra note 623 at 6.

${ }^{629}$ Schneider, supra note 26 at 59-60.

${ }^{630}$ Brower, supra note 86 at 296.
} 


\subsubsection{Submit all disputed issues to arbitration, both "legal" and "political"}

Complex interstate disputes such as those concerning territory commonly involve legal as well as non-legal issues, including historical, economic, and strategic interests, and issues of national identity and self-determination of people. Where such disputes are submitted to arbitration the full spectrum of these issues should be considered pursuant to the two-dimensional understanding of arbitration, otherwise the resolution of what may appear to be a simple border dispute will likely not bring an end to the deeper conflict between the parties. If state parties wish to obtain a fair and comprehensive decision that conclusively resolves their conflict, therefore, they would be well-advised to authorize the arbitrators to act as both "judges" and "diplomats" and decide on all the disputed issues by considering all relevant factors. The parties should also take care to submit to the arbitral tribunal all of their arguments, claims, and evidence, both legal and non-legal.

Moreover, parties should avoid including over-specific and potentially contradictory instructions in their arbitration agreement, or restricting the arbitral tribunal's authority to formulate a compromise solution. While state parties may fear an unpredictable outcome, a zero-sum award is likely to be rigid and exclude much of the parties' broader interests. If state parties are unable to agree on the precise issues to be submitted to arbitration or the scope of their dispute, they should allow the arbitral tribunal to decide on its own mandate rather than formulating an overlynarrow and restrictive arbitration agreement. Doing so may result in a partial and ineffective award, or, if the arbitral tribunal considers or decides relevant issues not explicitly submitted to but that are nonetheless indivisible, there could be a risk of non-compliance by the losing party on the ground that the tribunal has exceeded its authority.

\subsubsection{Authorize the arbitral tribunal to apply legal principles flexibly and consider non-legal factors}

States should avoid restricting the arbitral tribunal's decision-making power by choosing international legal principles or treaty interpretation to exclusively govern the resolution of a complex dispute submitted to arbitration, particularly where the disputed issues are not strictly legal in nature. States that wish to restrict the unpredictability of a binding decision by ensuring that the rules to be applied are those that will lead to a favourable solution might as well be 
declaring that they "agree to go to arbitration on the condition that [they] win the case". ${ }^{631}$ Such an approach is antithetical to the two-dimensional nature of the arbitral process and is likely to doom it to failure.

As the motivation of states to submit a complex dispute to arbitration in the first place is presumably, at least in part, to obtain an effective and fair resolution by a neutral third party, it is arguably counterproductive for them to tie the hands of their arbitrators by limiting their mandate to the strict application of the law, which will likely not be able to address all the issues, whether overt or covert, disputed by the parties. Therefore, parties should arguably authorize the arbitrators to decide legal issues in accordance with principles of law and equity inherent in international law, thus fulfilling their role as "judges", as well as non-legal issues in accordance with all relevant factors and the specific circumstances of the case, thus fulfilling their role as "diplomats", 632

\subsubsection{Consider empowering the arbitral tribunal to decide ex aequo et bono}

In order to utilize the two-dimensional nature of interstate arbitration and reinforce the arbitrators' ability to produce an effective and just award, state parties should consider allowing them to decide ex aequo et bono. While denying the arbitrators this power is a precaution intended to ensure that they decide the disputed issues purely on the basis of the law and thereby avoid arbitrary decisions, and may seem intuitively justified in interstate disputes involving "vital interests", the true foundations of ex aequo et bono are not rooted in arbitrariness but are rather "situated in functional processes that are directed at resolving realistic, but often complex, problems". ${ }^{633}$ Therefore, a "decision ex aequo et bono can be of value in cases where the settlement of non-juridical differences is concerned". 634

Deciding ex aequo et bono, moreover, does not necessarily mean disregarding law entirely, but may rather entail the exercise of "discriminating judgment on the practical and moral reasons by which to decide each case". ${ }^{635}$ Such decisions therefore "fit the arbitral function better than the

\footnotetext{
${ }^{631}$ Kenneth R. Simmonds, Ruth Lapidoth \& Hans W. Baade, "Roundtable: Public International Arbitration" (1987) 22 Tex Int'l LJ 149 at 157 [Simmonds, Lapidoth \& Baade].

${ }^{632}$ Munkman, supra note 6 at 21; Pinto, "Prospects", supra note 4 at 95.

633 Trakman, supra note 15 at 640.

${ }^{634}$ Pinto, "Prospects", supra note 4 at 89.

635 Trakman, supra note 15 at 640.
} 
properly judicial one", ${ }^{636}$ particularly when arbitration is viewed from a two-dimensional perspective. State parties may also authorize an arbitral tribunal to decide ex aequo et bono only "in so far as there is no rule of international law applicable to the particular question", 637 or "while having regard to the general principles of international law and respecting the contractual obligations and the final decisions of international tribunals which are binding on the parties". 638 Entirely excluding the arbitral tribunal's authority to make such judgment, on the other hand, is risky since "the absence of considerations of overall fairness often leads to bitterness and a sense of injustice". ${ }^{639}$ State parties should therefore recognize that by authorizing an arbitral tribunal to decide ex aequo et bono they are not necessarily excluding reliance on principles of law, ${ }^{640}$ but rather that "it is in fact a kind of international law governed by the ex aequo et bono principle that can provide the necessary flexibility within legal limits", 641

\subsubsection{Recognize that arbitration is not merely a flexible form of judicial settlement and fully participate in the arbitral process}

The reluctance on the part of states to use arbitration to resolve complex interstate disputes involving non-legal issues is arguably related to the modern one-dimensional "judicialized" (mis)perception of arbitration. ${ }^{642}$ States that perceive interstate arbitration as an essentially judicial mechanism based on the application of strict legal principles would understandably view it as unsuitable for the resolution of politically sensitive disputes that are not amenable to legal determination. This view of interstate arbitration, however, is erroneous and is a result of states' failure to recognize arbitration as a two-dimensional mechanism that offers an alternative to, rather than a more flexible form of, judicial settlement, and combines law and diplomacy to produce a binding compromise capable of settling all disputed issues between the parties. This failure, moreover, is in turn likely to result in interstate territorial disputes that have failed to be

\footnotetext{
${ }^{636}$ Pinto, "Prospects", supra note 4 at 89 . It has also been argued that ex aequo et bono is "ideally suited to resolving disputes between parties who are engaged in a complex and long-term relationships" or where "the law is either inadequately developed or unsuitable to resolve complex disputes", Trakman, supra note 15 at 621.

${ }^{637}$ Pinto, "Structure, Process, Outcome", supra note 2 at 262.

${ }^{638}$ Similar language was used, for instance, in the 1957 European Convention for the Peaceful Settlement of Disputes, online: 〈http://conventions.coe.int/Treaty/en/Treaties/Html/023.htm〉.

${ }^{639}$ Jibril, supra note 42 at 652.

${ }^{640}$ Trakman, supra note 15 at 641.

${ }^{641}$ Vicuña \& Pinto, supra note 48 at 331.

${ }^{642}$ Pinto, "Prospects", supra note 4 at 85.
} 
resolved by "diplomatic" means, and which states are reluctant to submit to judicial settlement, remaining unresolved and potentially deteriorating to armed conflict. ${ }^{643}$

At the same time, the recognition by states of arbitration's two-dimensional nature is necessary, but not always sufficient, for it to successfully resolve complex interstate disputes. States must also be invested in the arbitral process by freely choosing to submit their dispute to it. States that are coerced into agreeing to arbitration by external pressure and do not view it as an appropriate dispute resolution mechanism in the circumstances are unlikely to accept an outcome that requires them to make concessions. It should be recalled that any arbitration is inevitably dependent upon, and rooted in, the consent of the disputing parties' and their prior negotiations regarding the arbitration agreement and its terms. ${ }^{644}$ Without independent consent and sufficient involvement and engagement in designing the arbitral process, much of the parties' "shared understanding" ${ }^{\prime 65}$ of the two-dimensional benefits of arbitration would be lost and the arbitral award will likely not be implemented.

\subsection{Arbitral tribunals}

\subsubsection{Interpret the arbitration agreement as broadly as possible}

An arbitral tribunal that views its mandate narrowly and limits the arbitral process only to questions of law and its own jurisdiction only to the application of legal principles may perhaps simplify its task and stay within its area of expertise, however "what tends to be lost in the

process is the wider perspective that relates to the distinctive social setting of the case". 646 Therefore, arbitral tribunals hearing complex interstate disputes should adopt a two-dimensional broad approach to the parties' compromis and to their own role and decide the dispute before them on the basis of law, equity, justice, and all relevant factors, and in a way that best serves the interests of the parties and accounts for potential domestic and regional implications. While arbitrators should generally remain within the limits placed on their mandate by the parties, at least where such limits are clear and unequivocal, they should not "remain within the often strict

\footnotetext{
${ }^{643}$ Pan, supra note 20 at $1,19,30$.

${ }^{644}$ Merrills, "International Boundary Disputes", supra note 6 at 101.

${ }^{645}$ Brunnée \& Toope, supra note 133 at 135.

${ }^{646}$ Clapham, supra note 599 at 168.
} 
conditions imposed by the parties requesting arbitration...nor adhere dogmatically to a restrictive mandate given by state regimes with manifest political aims". 647

Without a two-dimensional approach to the interpretation of the parties' arbitration agreement and any restrictive instructions contained within it, and the conscious exercise of the arbitrators' discretion and foresight with respect to their own mandate and authority and with the aim of effectively resolving the parties' dispute, the outcome of the arbitration may be legalistic, narrow, partial, unsatisfactory, and ineffective. Moreover, since their goal should be to produce an arbitral award that is balanced, fair, sound, and effective, arbitrators should avoid to the extent possible non liquet or non licet decisions arising from parties' insufficient or inadequate instructions, which both undermine the tribunal's authority and mandate and may leave a disputed issue unresolved. Rather, arbitral tribunals should interpret their mandate and the parties' motives as broadly and creatively as possible within the borders of the arbitration agreement in order to formulate a flexible decision that would provide the parties with an effective resolution to their dispute.

\subsubsection{Apply international law flexibly and equitably and consider non-legal factors}

As part of the "legal dimension" of interstate arbitration and their role as "judges", arbitrators should consider all of the parties' arguments and claims, give reasons for their decisions, and apply international law to the extent it is relevant, suitable, and conducive to the resolution of the dispute before them. Arbitrators should also give due weight to equity in the application of international law, interpret legal principles flexibly, and avoid a rigid and legalistic approach to the resolution of the dispute, keeping in mind that "facts and law alone cannot deal with problems that may require compromised settlement". ${ }^{648}$ While law certainly plays a role in interstate arbitration, it is arguably a secondary role and even well-established legal principles should not be rigidly applied if this would lead to an impractical or demonstrably unfair result. While "a legalistic determination" may be possible in many interstate disputes, ${ }^{649}$ "ignorance of

\footnotetext{
${ }^{647}$ Abbink, supra note 520 at 157.

648 Jeong, supra note 6 at 176.

${ }^{649}$ Kratochwil, Rohrlich \& Mahajan, supra note 186 at 76.
} 
underlying emotional or value differences often contributes to further deepening an irreconcilable breakdown in relations between the parties". 650

As part of the "diplomatic dimension" of interstate arbitration and their role as "diplomats", arbitrators should consider the broader circumstances and context of the dispute and its underlying causes, the regional traditions of the parties, state practice, social norms, and any other relevant non-legal factors. ${ }^{651}$ They should attempt to formulate a creative solution that accounts for political and cultural realities and that would be acceptable to both parties, even if it may not strictly conform to generally accepted principles of international law. Such a decision, however, must be grounded in solid, relevant, and legitimate considerations, and not be, or appear to be, arbitrary. While reference to local and regional legal traditions and social norms and customs may have the potential to "create inconsistencies in international law", 652 such inconsistency should arguably not be the primary concern of an ad hoc arbitral tribunal tasked with the resolution of a particular interstate dispute to which such considerations are relevant. Such an arbitral tribunal, in contrast to an international permanent court, should arguably concern itself first and foremost with the particular interests of the parties and the fair and just resolution of the dispute before it, rather than the preservation of international legal rules and principles that may be ill-suited to the particular context of the dispute.

As each and every interstate dispute involves a unique constellation of facts, interests, and considerations, in order to properly utilize the two-dimensional advantages of arbitration all relevant factors must be examined and considered, legal as well as non-legal, explicit as well as implicit. At the same time, arbitrators should exercise discretion in allocating appropriate weight in their decision making to the parties' various arguments and claims in light of the specific context of the dispute, and to each of the "legal" and "diplomatic" dimensions of the arbitral process. In so doing, they should also not be reluctant to base their decisions on non-legal factors or on relevant considerations not raised by the parties in lieu of applicable or relevant legal principles, where the effective resolution of the dispute so requires. If arbitration is to be successfully used to prevent conflict and maintain peace between states, it must give due attention to "the historical context, the local political setting and power struggles, the local

\footnotetext{
${ }^{650}$ Jeong, supra note 6 at 176.

${ }^{651}$ Himmelreich, supra note 187 at 990-991.

${ }^{652}$ Johnson, "Eritrea-Yemen”, supra note 374 at 435; Antunes, "First Stage”, supra note 378 at 385-386.
} 
perceptions on territoriality and governance, and the socio-ethnic composition of the disputed regions...it will [not] do to ignore questions of justice". 653

\subsubsection{Avoid a "winner-takes-all" decision}

Zero-sum solutions are generally impracticable in complex interstate disputes ${ }^{654}$ since "a decision in favour of one party will not help build harmonious relations". ${ }^{655}$ Moreover, if states are to accept and employ arbitration's two-dimensional hybrid nature, arbitrators should arguably act as conciliators of sorts and strive to produce a compromise solution that reconciles the parties' differences, rather than exacerbate them by a decision that favours one party's position at the expense of the other. In their role as "diplomats", therefore, arbitrators should consider elements beyond the disputed issues submitted to them "so as to enlarge the scope of a possible settlement and create the ground for an arrangement in which all parties find their advantage", 656 and in order to devise a broad and pragmatic compromise acceptable to both parties.

In their dual role as "judges" and "diplomats", moreover, arbitrators must maintain, and appear to maintain, an impartial perspective of the dispute and avoid "emotive" 657 decision making influenced by political pressures and what is often open hostility between the parties. A zero-sum award entirely upholding one party's position to the exclusion of the other may appear partial and biased in favour of the winning party and the probability of its implementation by the losing party greatly diminishes.

\subsubsection{Be aware of conditions on the ground}

In territorial or boundary disputes, and particularly those that may result in the division or displacement of communities, the arbitral tribunal should visit the disputed site and consider the position of the locals to the extent possible and feasible, in line with the two-dimensional approach to interstate arbitration. Arbitral tribunals that limit their considerations in making such crucial and far-reaching decisions to formalistic interpretations of legal texts or to strict legal principles and do not conduct independent fact-finding may end up rendering an award that,

\footnotetext{
${ }^{653}$ Abbink, supra note 520 at 157.

${ }^{654}$ Pan, supra note 20 at 4.

${ }^{655}$ Jeong, supra note 6 at 176.

${ }^{656}$ Schneider, supra note 26 at 66.

${ }^{657}$ Bowett, supra note 6 at 339.
} 
while perhaps legally sound, is impractical, unrealistic, and that cannot be implemented. Such an award has little prospects of being accepted by the parties and resolving their dispute.

\section{Conclusion}

One of the continuous goals of the international community is the prevention of war through peaceful resolution of interstate disputes. ${ }^{658}$ Although a host of dispute resolution mechanisms, from mediation to judicial settlement, has been developed for this purpose, this goal remains unattained. ${ }^{659}$ While some may consider this to be a result of the absence of a dispute resolution mechanism capable of settling interstate disputes definitively and effectively, ${ }^{660}$ this paper argues that such a mechanism, namely interstate arbitration, in fact exists and has been in existence for centuries.

Interstate arbitration has a long history of resolving political and military interstate conflicts ${ }^{661}$ and "prevent[ing] the recurrence of war" 662 by finding a middle ground based on both law and diplomacy that is accepted as binding and fair by disputing states. ${ }^{663}$ In the context of interstate territorial disputes that involve the most sensitive aspect of a state's existence, namely the extent of its sovereignty, ${ }^{664}$ and are not necessarily amenable to either purely "diplomatic" dispute resolution mechanisms or judicial determination, this two-dimensional traditional nature of arbitration is particularly invaluable.

Yet, with the gradual "judicialization" of interstate arbitration in modern times it has largely become a one-dimensional, legalistic, and formalistic "judicial process designed to reach a decision based on the application of legal principles". ${ }^{665}$ As a result, states have been reluctant to employ arbitration where non-legal or political issues are involved, arguably rendering it "the sleeping beauty of the Peace Palace". ${ }^{666}$ Nevertheless, the original hybrid "essence" 667 of interstate arbitration can arguably be restored if its two-dimensional character and the complex

\footnotetext{
${ }^{658}$ Reisman, "Reflections", supra note 23 at 6, 13.

${ }^{659}$ Muller \& Mijs, supra note 1 at 203.

${ }^{660}$ Ibid.

${ }^{661}$ Fry, supra note 6 at 419; Werner, supra note 13 at 69.

${ }^{662}$ Hague Conference of 1899, cited in Werner, Ibid at 73.

${ }^{663}$ Holtzmann, "Reflections", supra note 144 at 266.

${ }^{664}$ Lauterpacht, supra note 296 at 465-466.

${ }^{665}$ Holtzmann, "Reflections", supra note 144 at 266.

${ }^{666}$ Muller \& Mijs, supra note 1 at 204.

${ }^{667}$ Pinto, "Structure, Process, Outcome", supra note 2 at 261.
} 
nature of most interstate disputes are recognized and duly considered. Granted, there may never be real peace between disputing states that do not "want it badly enough" ${ }^{668}$ but if the twodimensional "true nature" of arbitration is revived, it will arguably be most likely to achieve it where they do.

${ }^{668}$ Daniel Bethlehem, "Is There a Role for International Law in the Middle East Peace Process?", Comments from ASIL proceedings, 2005, 99 Am Soc'y Int'l L Proc 213 at 220. 


\section{Bibliography}

\section{Arbitral Awards and Related Documents}

Beagle Channel Arbitration between Chile and Argentina:

Argentina v Chile (1977), 17:3 ILM 634.

Treaty of Arbitration concluded between Argentina and Chile, signed May, 28, 1902 (Argentina and Chile), 28 May 1902, 1:3 Am J Int'1 L, Supplement: Official Documents 290.

Agreement for Arbitration (Compromiso) of a Controversy Between the Argentine Republic and the Republic of Chile Concerning the Region of the Beagle Channel, July 22, 1971(Argentina and Chile), 22 July 1971, 66 Am J Int'1 L 461.

Declaration of Her Majesty Queen Elizabeth II, Pursuant to the Agreement For Arbitration (Compromiso) Determined by the Government of the United Kingdom of Great Britain and Northern Ireland and Signed on Behalf of That Government and the Governments of the Argentine Republic and the Republic of Chile on 22 July 1971 for the Arbitration of a Controversy Between the Argentine Republic and the Republic of Chile Concerning the Region of the Beagle Channel, 1978, 17:3 ILM 632.

Argentina-Chile: Exchange of Diplomatic Notes Concerning the Beagle Channel Arbitration, 25-26January 1978, 17:3 ILM 738.

Note from the President of the Court of Arbitration to the United Kingdom with regard to the Execution of the Award, 10 July 1978, 17:5 ILM 1198.

Treaty of Peace and Friendship between Chile and Argentina (with annexes and maps), $29 \quad$ November 1984, online: <http://www.un.org/Depts/los/LEGISLATIONANDTREATIES/PDFFILES/TREATI ES/CHL-ARG1984PF.PDF>.

Taba Arbitration between Israel and Egypt:

Israel v Egypt (1988), 20 Rep Int'l Arb Awards 3.

Agreement to Arbitrate the Boundary Dispute Concerning the Taba Beachfront (Israel and Egypt), 11 September 1986, 26 ILM 1.

Israel-Egypt Agreements on Taba, 26 February 1989, 23 Isr L Rev 111. 
Red Sea (Hanish) Islands Arbitration between Eritrea and Yemen:

Eritrea $v$ Yemen (1998) Award of the Arbitral Tribunal in the First Stage of the Proceedings (Territorial Sovereignty and Scope of the Dispute), Permanent Court of Arbitration, online: <http://www.pca-cpa.org/showpage.asp?pag_id=1160>

Eritrea $v$ Yemen (1999) Award of the Arbitral Tribunal in the Second Stage of the Proceedings (Maritime Delimitation), Permanent Court of Arbitration, online: $<$ http://www.pca-cpa.org/showpage.asp?pag_id=1160>

Arbitration Agreement (Eritrea and Yemen), 3 October1996, Republic of Yemen National Information Centre, online: <http://www.yemennic.net/English\%20site/SITE\%20CONTAINTS/about\%20yemen/agreements/Eritrea\% 20-\%20Yemen\%20Arbitration/Eritrea-Yemen\%20Award\%20phase\%202/ERYEarbagree\%201.htm>

Eritrea-Ethiopia Boundary Commission:

Eritrea v Ethiopia (2002), Decision Regarding Delimitation of the Border Between the State of Eritrea and the Federal Democratic Republic of Ethiopia, 41:5 ILM 1057.

Agreement Between the Government of the Federal Democratic Republic of Ethiopia and the Government of the State of Eritrea (Eritrea and Ethiopia), 12 December 2000, Permanent Court of Arbitration, online: <http://www.pcacpa.org/showpage.asp?pag_id=1150>.

Decision Regarding the 'Request for Interpretation, Correction and Consultation' Submitted by the Federal Democratic Republic of Ethiopia on 13 May 2002, 24 June 2002, Permanent Court of Arbitration, online: <http://www.pcacpa.org/showpage.asp?pag_id=1150>.

\section{Books}

Allain, Jean. A Century of International Adjudication: The Rules of Law and its Limits (The Hague: T.M.C. Asser Press, 2000).

Amerasinghe, Ranjan Felix C. International Arbitral Jurisdiction (Martinus Nijhoff Publishers, 2011).

Bailey, Sydney D. How Wars End: The United Nations and the Termination of Armed Conflict 1946-1964 (Oxford: Clarendon Press, 1982).

Bentwich, Norman \& Andrew Martin. A Commentary on the Charter of the United Nations (London: Routledge \& Kegan Paul Ltd., 1950). 
Bercovitch Jacob \& Judith Fretter. Regional Guide to International Conflict and Management From 1945 to 2003 (California: CQ Press, 2004).

Biehler, Gernot. Procedures in International Law (Berlin: Springer-Verlag, 2008).

Boas, Gideon. Public International Law: Contemporary Principles and Perspectives (Cheltenham: Edward Elgar, 2012).

Booth, Wayne C., Gregory G. Colomb \& Joseph M. Williams, The Craft of Research, 3rd ed (Chicago, London: The University of Chicago Press, 2008).

Born, Gary B. International Arbitration: Law and Practice (The Hague: Kluwer Law International, 2012).

---.International Commercial Arbitration (The Hague: Kluwer Law International, 2009).

---. International Commercial Arbitration: Commentary and Materials, 2nd ed (The Hague: Kluwer Law International, 2001).

Calpham, Andrew. Brierly's Law of Nations, 7th ed (Oxford: Oxford University Press, 2012).

Caron, David D. \& John R. Crook, eds. The Iran-United States Claims Tribunal and the Process of International Claims Resolution (New York: Transnational Publishers, Inc., 2000).

Collier, John \&Vaughan Lowe. The Settlement of Disputes in International Law: Institutions and Procedures (Oxford: Oxford University Press, 1999).

Dunoff, Jeffrey L., Steven R. Ratner \& David Wippman. International Law: Norms, Actors, Process A Problem-Oriented Approach, 2nd ed (New York, Aspen Publishers, 2006).

French, Duncan, Matthew Saul \& Nigel D. White. International Law and Dispute Settlement: New Problems and Techniques (Oxford and Portland, Oregon, Hart Publishing, 2010).

Gillham, Bill. Case Study Research Methods (London, New York: Continuum, 2000).

Hamilton P. et al. eds. The Permanent Court of Arbitration: International Arbitration and Dispute Resolution (The Hague: Kluwer Law International, 1999).

Hobér, Kaj. Essays on International Arbitration (Juris Publishing, Inc., 2006).

Huth, Paul K. \& Todd L. Allee. The Democratic Peace and Territorial Conflict in the Twentieth Century (Cambridge: Cambridge University Press, 2002). 
Jeong, Ho-Won. Peace and Conflict Studies: An Introduction (Hants, England: Ashgate Publishing Ltd., 2000).

Koopmans, Sven M.G. Diplomatic Dispute Settlement: The Use of Inter-State Conciliation (The Hague: T.M.C. Asser Press, 2008).

Kratochwil, Friedrich, Paul Rohrlich \& Arpreet Mahajan. Peace and Disputed Sovereignty: Reflections on Conflict Over Territory (Lanham, MD: University Press of America, 1985).

Mackenzie, Ruth, et al. The Manual on International Courts and Tribunals, 2nd ed (Oxford: Oxford University Press, 2010).

Macmahon, Belinda \& Fedelma Claire Smith. Permanent Court of Arbitration Summaries of Awards 1999-2009 (The Hague, T.M.C. Asser Press, 2010).

Matheson, Michael J. International Civil Tribunals and Armed Conflict (Leiden, The Netherlands: Martinus Nijhoff Publishers, 2012).

Merrills, J.G. International Dispute Settlement (Cambridge: Cambridge University Press, 2011).

Pan, Junwu. Toward a New Framework for Peaceful Settlement of China's Territorial and Boundary Disputes (Leiden, The Netherlands: Martinus Nijhoff Publishers, 2009).

Rabow, Gerald. Peace Through Agreement: Replacing War with Non-Violent DisputeResolution Methods (New York: Praeger Publishers, 1990).

Ralston, Jackson H. International Arbitration from Athens to Locarno (California: Stanford University Press, 1929).

Richard, Henry. Arbitration: Two Views: The Recent Progress (New York: Garland Publishing, 1971).

Schulte, Constanze. Compliance with Decisions of the International Court of Justice (Oxford: Oxford University Press, 2004).

Schwebel, Stephen M. Justice in International Law (Cambridge: Cambridge University Press, 2011).

Schweigman David. The Authority of the Security Council Under Chapter VII of the UN Charter: Legal Limits and the Role of the International Court of Justice (The Hague: Kluwer Law International, 2001). 
Stansfield, Gareth R.V. The 1995-96 Yemen-Eritrea Conflict over the Islands of Hanish and Jabal Zuqar: A Geopolitical Analysis (Durham, United Kingdom: Center for Middle Eastern and Islamic Studies, 2001).

Study Group of the David Davies Memorial Institute of International Studies. International Disputes: The Legal Aspects (London: Europa Publications, 1972).

Terrett, Steve. The dissolution of Yugoslavia and the Badinter Arbitration Commission: A Contextual Study of Peace-Making Efforts in the Post-Cold War World (Aldershot, U.K., Burlington, VT: Ashgate/Dartmouth, 2000).

Vicuña, Francisco Orrego. International Dispute Settlement in an Evolving Global Society: Constitutionalization, Accessibility, Privatization (Cambridge: Cambridge University Press, 2004).

Wallensteen, Peter. Understanding Conflict Resolution (London: SAGE Publications Ltd, 2012).

Yin, Robert K. Case Study Research: Design and Methods, 4th ed (Los Angeles, California: Sage Publications, 2009).

\section{Book Chapters and Collections of Essays}

Abbink, Jon. "Law Against Reality? Contextualizing the Ethiopian-Eritrean Border Problem" in Andrea de Guttry, Harry H.G. Post \& Gabriella Venturini, eds, The 1998-2000 War between Eritrea and Ethiopia (The Hague: T.M.C. Asser Press, 2009) 141-158.

Addo, Michael K. "The Role of Intergovernmental Agencies in the Management of Human Rights Risk" in Andrea de Guttry, Harry H.G. Post \& Gabriella Venturini, eds, The 1998-2000 War between Eritrea and Ethiopia (The Hague: T.M.C. Asser Press, 2009) 449-472.

Bilder, Richard B. "Some Limitations of Adjudication as an International Dispute Settlement Technique" in Thomas E. Carbonneau, ed, Resolving Transnational Disputes Through International Arbitration (Charlottesville: University Press of Virginia, 1982) 3-14.

---. “Adjudication: International Arbitral Tribunals and Courts" in I. William Zartman, ed, Peacemaking in International Conflict: Methods \& Techniques (Washington, D.C.: United States Institute of Peace, 2007) 195-226.

Brunnée, Jutta \& Stephen J. Toope. "Constructivist Approaches to International Law" in Jeffrey L. Dunoff \& Mark A. Pollack, eds, Interdisciplinary Perspectives on International Law and International Relations: The State of the Art (Cambridge University Press, 2012) 119-145. 
Chapman, Michael. "The Interlaced History of Public and Commercial Arbitration, 1794 to 1999" in The International Bureau of the Permanent Court of Arbitration, ed, International Alternative Dispute Resolution: Past, Present and Future (The Hague: Kluwer Law International, 2000) 75-90.

Clapham, Christopher. "Indigenous Statehood and International Law in Ethiopia and Eritrea" in Andrea de Guttry, Harry H.G. Post \& Gabriella Venturini, eds, The 1998-2000 War between Eritrea and Ethiopia (The Hague: T.M.C. Asser Press, 2009) 159-170.

Corell, Hans. "The Feasibility of Implementing the Hague/St. Petersburg Centennial Recommendations Under the UN System" in Julie Dahlitz, ed, Peaceful Resolution of Major International Disputes (New York: United Nations, 1999) 31-48.

Crook, John R. "Fact-Finding in the Fog: Determining the Facts of Upheavals and Wars in Inter-State Disputes" in Catherine A. Rogers \& Roger P. Alford, eds, The Future of Investment Arbitration (New York: Oxford University Press, 2009) 313-338.

Daly, Brooks W. "Permanent Court of Arbitration" in Chiara Giorgetti, ed. The Rules, Practice, and Jurisprudence of International Courts and Tribunals (Leiden: Martinus Nijhoff Publishers, 2012) 37-76.

Dirar, Uoldelul Chelati. "Rivalry, Antagonism and War in the Nation 7 State-building Process: The H Factor in the Relations Between Eritrea and Ethiopia" in Andrea de Guttry, Harry H.G. Post \& Gabriella Venturini, eds, The 1998-2000 War between Eritrea and Ethiopia (The Hague: T.M.C. Asser Press, 2009) 25-52.

Fox, Hazel. "Arbitration" in Evan Luard, ed, The International Regulation of Frontier Disputes (New York, Washington: Praeger Publishers, 1970) 168-197.

Gilkes, Patrick. "Violence and Identity along the Eritrean-Ethiopian Border" in Dominique Jacquin-Berdal \& Martin Plaut, eds, Unfinished Business: Ethiopia and Eritrea at War (The Red Sea Press, Inc., 2005) 229-253.

Gray, Christine \& Benedict Kingsbury. "Inter-state Arbitration since 1945: Overview and Evaluation" in Mark W. Janis, ed, International Courts for the Twenty-First Century (Dordrecht, Boston: Martinus Nijhoff Publishers, 1992) 55-83.

Greppi, Edoardo. "The 2000 Algiers Agreements", in Andrea de Guttry, Harry H.G. Post \& Gabriella Venturini, eds, The 1998-2000 War between Eritrea and Ethiopia (The Hague: T.M.C. Asser Press, 2009) 55-77.

Guazzini, Federica. "The Eritrean-Ethiopian Boundary Conflict: the Physical Border and the Human Border" in Andrea de Guttry, Harry H.G. Post \& Gabriella Venturini, eds, The 1998-2000 War between Eritrea and Ethiopia (The Hague: T.M.C. Asser Press, 2009) 109-140. 
Hensel, Paul R. "Territory: Theory and Evidence on Geography and Conflict," in John A. Vasquez, ed, What Do We Know About War? (Maryland, Oxford: Rowman \& Littlefield Publishers, Inc., 2000) 57-84.

Holtzmann, Howard M. "The Permanent Court of Arbitration and the Evolution of a Worldwide Arbitration Culture" in The International Bureau of the Permanent Court of Arbitration, ed, International Alternative Dispute Resolution: Past, Present and Future (The Hague: Kluwer Law International, 2000) 97-112.

---. "Some Reflections on the Nature of Arbitration" in Sam Muller and Wim Mijs, eds, The Flame Rekindled: New Hopes for International Arbitration (The Netherlands: Martinus Nijhoff Publishers, 1994) at 67-80.

Hopkinson, William G. "Overcoming Diplomatic Inertia and Constraint in the Resolution of Major Conflict" in Julie Dahlitz, ed, Peaceful Resolution of Major International Disputes (New York: United Nations, 1999) 77-83.

Jacquin-Berdal, Dominique. "Introduction-The Eritrea-Ethiopian War" in Dominique Jacquin-Berdal\& Martin Plaut, eds, Unfinished Business: Ethiopia and Eritrea at War (The Red Sea Press, Inc., 2005) ix-xxi.

Kaikobad, Kaiyan Homi. "The Eritrea-Ethiopia Boundary Commission: A Legal Analysis of the Boundary Delimitation Decision of 13th April 2002 and Relevant Subsequent Decisions" in Andrea de Guttry, Harry H.G. Post \& Gabriella Venturini, eds, The 1998-2000 War between Eritrea and Ethiopia (The Hague: T.M.C. Asser Press, 2009) 171-223.

Kooijmans, P.H. "International Arbitration in Historical Perspective: Past and Present, Comments on a paper by Professor L.B. Sohn" in A.H.A. Soons, ed, International Arbitration: Past and Prospects (The Netherlands: Martinus Nijhoff Publishers, 1990) 23-35.

Lachs, M. "Arbitration and International Adjudication" in A.H.A. Soons, ed, International Arbitration: Past and Prospects (The Netherlands: Martinus Nijhoff Publishers, 1990) 37-54.

Laudy, Mark. "The Vatican Mediation of the Beagle Channel Dispute: Crisis Intervention and Forum Building" in Melanie C. Greenberg, John H. Barton \& Margaret E. McGuinness, eds, Words Over War: Mediation and Arbitration to Prevent Deadly Conflict (Oxford: Rowman \& Littlefield Publishers, Inc., 2000) 293-320.

Luard, Evan. "Frontier Disputes in Modern International Relations" in Evan Luard, ed, The International Regulation of Frontier Disputes (New York, Washington: Praeger Publishers, 1970) 7-30. 
---. "Conclusions" in Evan Luard, ed, The International Regulation of Frontier Disputes (New York, Washington: Praeger Publishers, 1970) 221-239.

McWhinney, Edward. "The International Court as Constitutional Court and the Blurring of the Arbitral/Judicial Processes" in Sam Muller and Wim Mijs, eds, The Flame Rekindled: New Hopes for International Arbitration (The Netherlands: Martinus Nijhoff Publishers, 1994) 81-89.

Merrills, J.G. "International Boundary Disputes in Theory and in Practice: Precedents Established" in Julie Dahlitz, ed, Peaceful Resolution of Major International Disputes (New York: United Nations, 1999) 95-112.

---. "Reflections on Dispute Settlement in the Light of Recent Arbitrations Involving Eritrea" in Aristotle Constantinides \& N. Zaïkos, The Diversity of International Law: Essays in Honour of Professor Kalliopi K. Koufa (Leiden; Boston: Martinus Nijhoff Publishers, 2009) 109-130.

---. "The Contribution of the Permanent Court of Arbitration to International Law: 19992009" in Belinda Macmahon \& Fedelma Claire Smith, eds, Permanent Court of Arbitration Summaries of Awards 1999-2009 (T.M.C. Asser Press, 2010) 3-35.

Pinto, M.C.W. "Structure, Process, Outcome: Thoughts on the 'Essence' of International Arbitration" in Sam Muller and Wim Mijs, eds, The Flame Rekindled: New Hopes for International Arbitration (The Netherlands: Martinus Nijhoff Publishers, 1994) 43-66.

---. "The Prospects for International Arbitration: Inter-State Disputes" in A.H.A. Soons, ed, International Arbitration: Past and Prospects (The Netherlands: Martinus Nijhoff Publishers, 1990) 63-99.

Plaut, Martin. "Background to War - From Friends to Foes" in Dominique Jacquin-Berdal \& Martin Plaut, eds, Unfinished Business: Ethiopia and Eritrea at War (The Red Sea Press, Inc., 2005) 2-22.

---. "The Conflict and its Aftermath" in Dominique Jacquin-Berdal\& Martin Plaut, eds, Unfinished Business: Ethiopia and Eritrea at War (The Red Sea Press, Inc., 2005) 87123.

Novati, Gian Paolo Calchi. "The Lines of Tension in the Horn and the Ethiopia-Eritrea Case" in Andrea de Guttry, Harry H.G. Post \& Gabriella Venturini, eds, The 1998-2000 War between Eritrea and Ethiopia (The Hague: T.M.C. Asser Press, 2009) 3-20.

Pocar, Fausto. "Introductory Remarks" in Andrea de Guttry, Harry H.G. Post \& Gabriella Venturini, eds, The 1998-2000 War between Eritrea and Ethiopia (The Hague: T.M.C. Asser Press, 2009) xiii-xviii. 
Queneudec, Jean-Pierre. "The Eritrea-Yemen Arbitration: Its Contribution to International Law" in Bette Shifman, ed, Permanent Court of Arbitration Award Series: The EritreaYemen Arbitration Awards 1998 and 1999 (T.M.C. Asser Press, 2005) 1-16.

Reed, Lucy. "Arbitration Principles Prove Effective in Resolving Holocaust Bank Claims" in The International Bureau of the Permanent Court of Arbitration, ed, Institutional and Procedural Aspects of Mass Claims Settlement Systems, Papers emanating from the PCA International Law Seminar on December 9, 1999 (The Hague: Kluwer Law International, 2000) 59-72.

Reid, Richard. “'Ethiopians believe in God, Sha'abiya believe in mountains': the EPLF and the 1998-2000 war in historical perspective" in Dominique Jacquin-Berdal \& Martin Plaut, eds, Unfinished Business: Ethiopia and Eritrea at War (The Red Sea Press, Inc., 2005) 23-36.

Rusk, Dean. "The Role and Problems of Arbitration with Respect to Political Disputes" in Thomas E. Carbonneau, ed, Resolving Transnational Disputes Through International Arbitration (Charlottesville: University Press of Virginia, 1982) 15-20.

Sohn, L.B. "International Arbitration in Historical Perspective: Past and Present" in A.H.A. Soons, ed, International Arbitration: Past and Prospects (The Netherlands: Martinus Nijhoff Publishers, 1990) 9-22.

Shaw, Malcolm N. "Peaceful Resolution of 'Political Disputes': The Desirable Parameters of ICJ Jurisdiction" in Julie Dahlitz, ed, Peaceful Resolution of Major International Disputes (New York: United Nations, 1999) 49-75.

Vicuña, Francisco Orrego. "A Perspective of Dispute Settlement Arrangements for the Twenty-First Century" in Timothy H. McCormack, Michael Tilbury \& Gillian D. Triggs, eds, A Century of War and Peace: Asia-Pacific Perspectives on the Centenary of the 1899 Hague Peace Conference (The Hague: Kluwer Law International, 2001) 43-57.

Vicuña, Francisco Orrego \& Christopher Pinto. "Peaceful Settlement of Disputes: Prospects for the $21^{\text {st }}$ Century, Revised Report Prepared for the Centennial of the First International Peace Conference" in Frits Kalshoven, ed, The Centennial of the First International Peace Conference: Reports \& Conclusions (The Hague: Kluwer Law International, 2000) 261-416.

Zewde, Bahru. "The Historical Background of the 1998-2000 War: Some Salient Points" in Andrea de Guttry, Harry H.G. Post \& Gabriella Venturini, eds, The 1998-2000 War between Eritrea and Ethiopia (The Hague: T.M.C. Asser Press, 2009) 21-24. 


\section{Articles}

Allee, Todd L. \& Paul K. Huth. "The Pursuit of Legal Settlements to Territorial Disputes" (2006) 23 Conflict Management and Peace Science 285.

Anstis, Sebastian C. St. J. \& Mark W. Zacher. "The Normative Bases of the Global Territorial Order" (2010) 21 Diplomacy \& Statecraft 306.

Antunes, Nuno Sérgio Marques. "The Eritrea-Yemen arbitration: First Stage - the Law of Title to Territory Re-Averred" (1999) 48:2 ICLQ 362.

---. "The 1999 Eritrea-Yemen Maritime Delimitation Award and the Development of International Law" (2001) 50:2 ICLQ 299.

Aran, Amnon. "Arbitrating the Israeli-Palestinian Territorial Dispute: A Riposte" (2012) 49:3 International Politics 388.

Bilder, Richard B. "International Third Party Dispute settlement" (1988-1989) 17 Denver J Int'l L \& Pol'y 471.

Böckstiegel, Karl-Heinz. "The Effectiveness of Inter-State Arbitration in Political Turmoil" (1993) 10:1 J Int'l Arb 43.

---. “The Role of Arbitration within Today's Challenges to the World Community and to International Law" (2006) 22:2 Journal of the London Court of International Arbitration 165.

Bowett, D.W. “The Taba Award of 29 September 1988” (1989) 23 Isr L Rev 429.

Brower, Charles H. II. "The Functions and Limits of Arbitration and Judicial Settlement Under Private and Public International Law" (2007-2008) 18 Duke J Comp \& Int'l L 259.

Brower, Charles N. \& Stephan W. Schill. "Is Arbitration a Threat or a Boon to the Legitimacy of International Investment Law?” (2008-2009) 9 Chicago J Int'1 L 471.

Carbonneau, Thomas E. "Commercial Peace and Political Competition in the Crosshairs of International Arbitration” (2007-2008) 18 Duke J Comp \& Int'1 L 311.

Caron, David D. "The Nature of the Iran-United States Claims Tribunal and the Evolving Structure of International Dispute Resolution” (1990) 84 Am J Int'1 L 104.

Charney, Jonathan I. "Third Party Dispute Settlement and International Law" (1998) 36 Colum J Transnat'1 L 65. 
Claussen, Kathleen. “Invisible Borders: Mapping Out Virtual Law?” (2009) 37:2 Denv J Int'1 L \& Pol'y 257.

Copeland, Carla S. "The Use of Arbitration to Settle Territorial Disputes" (1998-1999) 67 Fordham L Rev 3073.

Craik, Neil A. "Recalcitrant Reality and Chosen Ideals: The Public Function of Dispute Settlement in International Environmental Law" (1997-1998) 10 Geo Int'l Envtl L Rev 551.

Ding, Haihua \& Eric S. Koenig. "Treaties-Treaty of Peace Between Egypt and Israel Demarcation of Internationally Recognized Boundaries - Arbitration of Disputes Taba" (1989) 83 Am J Int'l L 590.

Dinstein, Yoram. "psak haborerut be parashat taba" (1989) 14 Tel Aviv U L Rev 57 (in Hebrew).

Dress, Toby P. "International Commercial Mediation and Conciliation" (1988) 10 Loy LA Int’1 \& Comp LJ 569.

Dybnis, Ari. "Was the Eritrea-Ethiopia Claims Commission Merely a Zero-Sum Game?: Exposing the Limits of Arbitration in Resolving Violent Transnational Conflict" (20102011) 33 Loy LA Int'l \& Comp L Rev 255.

Dzurek, Daniel J. "Eritrea-Yemen Dispute Over the Hanish Islands" (Spring 1996) IBRU Boundary and Security Bulletin 70.

Evans, Malcolm D. "The Maritime Delimitation Between Eritrea and Yemen" (2001)14:1 Leiden J Int'1 L141.

F.V. “The Beagle Channel Affair” (1977) 71:4 Am J Int'l L 733.

Fry, James D. “Arbitrating Arms Control Disputes” (2008) 44 Stan J Int'l L 359.

Gent, Stephen E. \& Megan Shannon. "The Effectiveness of International Arbitration and Adjudication: Getting Into a Bind" (2010) 72:2 Journal of Politics 366.

Grange, Leah C. "The Role of International Tribunals in Natural Resource Disputes in Latin America” (2007) 34 Ecology LQ 1297.

Gray, Christine. "The Eritrea/Ethiopia Claims Commission Oversteps Its Boundaries: A Partial Award?" (2006) 17:4 EJIL 699.

Gray, Christine \& Benedict Kingsbury. "Developments in Dispute Settlement: Inter-State Arbitration Since 1945” (1992) LXIII Brit YB Int'l L 97. 
Greig, D.W. “The Beagle Channel Arbitration” (1976-1977) 7 Aust YBIL 332.

Helfer, Laruence R. \& Slaughter, Anne-Marie. "Toward a Theory of Effective Supranational Adjudication" (1997-1998) 107 Yale LJ 273.

Himmelreich, David M. "The Beagle Channel Affair: A Failure in Judicial Persuasion" (1979) 12 Vand J Transnat'l L 971.

Holtzmann, Howard M. "Some Reflections on the Nature of Arbitration" (1993) 6 Leiden J Int'l L 265.

Huth, Paul K., Sarah E. Croco \& Benjamin J. Appel. "Bringing Law to the Table: Legal Claims, Focal Points, and the Settlement of Territorial Disputes Since 1945" (2013) 57:1 American Journal of Political Science 90.

Jibril, Nejib. "The Binding Dilemma: From Bakassi to Badme - Making States Comply with Territorial Decisions of International Judicial Bodies" (2003-2004) 19 Am U Int'1 L Rev 633.

Johnson, Constance. “Eritrea-Yemen Arbitration” (2000) 13:2 Leiden J Int’l L 427.

Johnson, D.H.N. “International Arbitration Back in Favour?"(1980) 34 Yearbook of World Affairs 305.

Kemp, A. \& U. Ben-Eliezer. "Dramatizing Sovereignty: the Construction of Territorial Dispute in the Israeli-Egyptian Border at Taba" (2000) 19:3 Political Geography 315.

King, Henry T. Jr. \& James D. Graham. "Origins of Modern International Arbitration" (1996) 12(1) Dispute Resolution Journal 42.

Kwiatkowska, Barbara. "The Eritrea-Yemen Arbitration: Landmark Progress in the Acquisition of Territorial Sovereignty and Equitable Maritime Boundary Delimitation" (2001) 32:1 Ocean Devel \& Int'l L 1.

---. "Current Legal Developments-Red Sea: Award of the Arbitral Tribunal in the First Stage of the Eritrea/Yemen Proceedings" (1999) 14 Int'l J. Marine \& Coastal L. 125.

Lachs, Manfred. "Equity in Arbitration and in Judicial Settlement of Disputes" (1993) 6 Leiden J Int'l L 323.

Lagergren, Gunnar. “The Taba Tribunal 1986-1989” (1989) 1 Afr J Int'1 \& Comp L 525.

Lapidoth, Ruth. "Some Reflections on the Taba Award" (1992) 35 German Yearbook of International Law 224.

---. "The Taba Controversy" (1986) 37 Jerusalem Quarterly 29. 
Lauterpacht, E. "The Taba Case: Some Recollections and Reflections" (1989) 23 Isr L Rev 443.

Lefebvre, Jeffrey A. "Red Sea Security and the Geopolitical-Economy of the Hanish Islands Dispute" (1998) 52(3) Middle East Journal 367.

Lelewer, Joanne K. "International Commercial Arbitration as a Model for Resolving Treaty Disputes” (1988-1989) 21 NYU J Int'1 L \& Pol 379.

Lyons, Terrence. "The Ethiopia-Eritrea Conflict and the Search for Peace in the Horn of Africa" (2009) 120 Review of African Political Economy 167.

Malintoppi, Loretta. "Methods of Dispute Resolution in Inter-State Litigation: When States Go To Arbitration Rather Than Adjudication" (2006) 5 Law \& Prac Int'1 Courts \& Trib 133.

McCorquodale, Robert. "International Boundary Decisions - Pillars of Salt?”(1989) 48 Cambridge LJ 352.

McHugh, Aman Mahray. "Resolving International Boundary Disputes in Africa: A Case for the International Court of Justice" (2005-2006) 49 Howard LJ 209.

McWhinney, Edward. "The International Court as Constitutional Court and the Blurring of the Arbitral/Judicial Processes” (1993) 6 Leiden J Int'1 L 279.

Mollel, Andrew L. "Judicial Settlement of Armed Conflicts in International Law: Reflecting the 2005 International Court of Justice Decision in the Democratic Republic of Congo" (2007) 76 Nordic J Int'1 L 407.

Movsesian, Mark L. "International Commercial Arbitration and International Courts" (20072008) 18 Duke J Comp \& Int'l L 423.

Muller, Sam \& Wim Mus. “The Flame Rekindled” (1993) 6 Leiden J Int’1 L 203.

Munkman, A.L.W. "Adjudication and Adjustment - International Judicial Decisions and the Settlement of Territorial and Boundary Disputes (1972-1973) 46 Brit YB Int'1 L 1.

Noyes, John E. "The Functions of Compromissory Clauses in U.S. Treaties" (1993-1994) 34 Va J Int'1 L 831.

Odentun, Gbenga. "Africa before the International Courts: The Generational Gap in International Adjudication and Arbitration" (2004) 44(4) Ind J Int'1 L 701.

Petersmann, Ernst-Ulrich. "Proposals for Strengthening the UN Dispute Settlement System" (1999) 3 Max Planck UNYB 105. 
Pinto, M.C.W. "Structure, Process, Outcome: Thoughts on the 'Essence' of International Arbitration" (1993) 6 Leiden J Int'1 L 241.

Pratt, Martin. "A Terminal Crisis? Examining the Breakdown of the Eritrea-Ethiopia Boundary Dispute Resolution Process" (2006) 23 Conflict Management and Peace Science 329.

Posner, Eric A. \& John C. Yoo. "Judicial Independence in International Tribunals" (2005) 93:1 Cal L Rev 1.

Posner, Richard A. "Legal Formalism, Legal Realism, and the Interpretation of Statutes and the Constitution (1986-1987) 37 Case W Res L Rev 179.

Quigley, John. "The Role of Law in a Palestinian-Israeli Accommodation" (1999) 31 Case W. Res J Int'l L 351.

Raymond, Gregory A. "Demosthenes and democracies: Regime-types and arbitration outcomes" (1996) 22:1 International Interactions: Empirical and Theoretical Research in International Relations 1.

Reisman, Michael W. "Eritrea-Yemen Arbitration (Award, Phase II: Maritime Delimitation)" Bernard H. Oxman, ed, International Decisions(2000) 94 Am J Int'1 L 721.

---. "Stopping Wars and Making Peace: Reflections on the Ideology and Practice of Conflict Termination in Contemporary World Politics" (1998) 6 Tul J Int'l \& Comp L 5.

---. "The Government of the State of Eritrea and the Government of the Republic of Yemen, Award of the Arbitral Tribunal in the First Stage of the Proceedings (Territorial Sovereignty and Scope of the Dispute)" Bernard H. Oxman, ed, International Decisions (1999) 93 Am J Int'1 L 668.

Rosenne, Shabtai. "Some Thoughts on International Arbitration Today" (1993) 27 Isr L Rev 447.

Shaw, Malcolm. "The Beagle Channel Arbitration Award" (1978) 6:2 International Relations 415.

Shaw, Malcolm N. "Title, Control, and Closure? The Experience of the Eritrea-Ethiopia Boundary Commission" (2007) 56 ICLQ 755.

Simmonds, Kenneth R., Ruth Lapidoth \& Hans W. Baade. "Roundtable: Public International Arbitration" (1987) 22 Tex Int'l LJ 149.

Simmons, Beth A. "Capacity, Commitment, and Compliance: International Institutions and Territorial Disputes” (2002) 46 J Confl Resolution 829. 
Siniver, Asaf. "Arbitrating the Israeli-Palestinian Territorial Dispute" (2012) 49:1 International Politics 117.

Sohn, Louise B. "Peaceful Settlement of Disputes and International Security" (1987) 3:2 Negotiation Journal 155.

---. "The Role of Arbitration in Recent International Multilateral Treaties" (1982-1983) 23 Va J Int'1 L 171.

Spain, Anna. "Beyond Adjudication: Resolving International Resource Disputes in an Era of Climate Change" (2011) 30 Stan Envtl LJ 343.

---. "Integration Matters: Rethinking the Architecture of International Dispute Resolution" (2010) 32:1 U Pa J Int'1 L 1.

Srecko, Vidmar. "Compulsory Inter-State Arbitration of Territorial Disputes" (2002-2003) 31 Denv J Int'l L \& Pol'y 87.

Sullivan, Daniel S. "Effective International Dispute Settlement Mechanisms and the Necessary Condition of Liberal Democracy”(1992-1993) 81 Geo L J 2369.

Trakman, Leon. "Ex Aequoet Bono: Demystifying an Ancient Concept" (2007-2008) 8 Chicago J Int'l L 621.

Van Den Hout \& Tjaco T. "Resolution of International Disputes: The Role of the Permanent Court of Arbitration - Reflections on the Centenary of the 1907 Convention for the Pacific Settlement of International Disputes” (2008) 21 Leiden J Int'1 L 643.

Villicana, Román López \& M. Venkataraman."Public Policy Failure or Historical Debacle? A Study of Eritrea's Relations With Ethiopia Since 1991” (2006) 23:2 Review of Policy Research 549.

Weeramantry, Romesh J. “International Decisions” (2007) 101 Am J Int'1 L 616.

---. "International Decisions" (2005) 99 Am J Int'l L 465.

---. “International Decisions" (2006) 100 Am J Int'l L 201.

Weil, Prosper. "Some Observations on the Arbitral Award in the Taba Case" (1989) 23 Isr L Rev 1.

Werner, Jacques. "Interstate Political Arbitration: What Lies Next?" (1992) 9:1 J Int'l Arb 69. 
Young, Ernest A. "Supranational Rulings as Judgments and Precedents" (2007-2008) 18 Duke J Comp \& Int'l L 477.

Zegeye, Abebe \& Melakou Tegegn. "The Post-war Border Dispute between Ethiopia and Eritrea On the Brink of Another War?" (2008) 24:2 Journal of Developing Societies 245.

Zondi, Siphamandla\& Emmanuel Réjouis. "The Ethiopia-Eritrea Border Conflict and the Role of the International Community" (2006) 6:2 AJCR 69.

\section{Other Sources}

Bethlehem,Daniel. "Is There a Role for International Law in the Middle East Peace Process?”, Comments from ASIL proceedings, 2005, 99 Am Soc’y Int'l L Proc 213.

Bowett, D.W. Contemporary Developments in Legal Techniques in the Settlement of Disputes, Coursepack, (Hague Academy of International Law, Recueil des CoursAcadémie de droit international de la Haye, 1983) 169-211.

Lowe, Vaughan. "Is There a Role for International Law in the Middle East Peace Process?", Comments from ASIL proceedings, 2005, 99 Am Soc'y Int'l L Proc 213.

Report of the Special Committee on Principles of International Law concerning Friendly Relations and Co-operation among States in United Nations Juridical Book, 1964, online:

<http://untreaty.un.org/cod/UNJuridicalYearbook/pdfs/english/ByVolume/1964/chplll.pdf\#p age $=>$.

Schneider, Michael E. "Combining Arbitration with Conciliation" (2004) TDM 1, online: TDM <www.transnational-dispute-management.com/article.asp?key=35> .

Seifu, Getahun. "Ethiopian-Eritrean Conflict: Options for African Union Intervention" in "Managing Peace and Security in Africa: Essays on Approaches to interventions in African Conflicts" (December, 2012), The African Peace and Security Programme, Institute For peace and Security Studies, Addis Ababa University.

The Carter Center. "Approaches to Solving Territorial Conflicts: Sources, Situations, Scenarios, and Suggestions" (May 2010), online: The Carter Center $<$ http://www.cartercenter.org/resources/pdfs/news/peace_publications/conflict_resoluti on/Solving_Territorial_Conflicts.pdf $>$.

Ziadé, Nassib G. "Is There a Role for International Law in the Middle East Peace Process?", Comments from ASIL proceedings, 2005, 99 Am Soc’y Int'1 L Pro 213. 